\title{
The State of Collective Bargaining in South Africa An Empirical and Conceptual Study of Collective Bargaining
}

\author{
Shane Godfrey \\ Jan Theron \\ Margareet Visser \\ Labour and Enterprise Policy Research Group \\ University of Cape Town \\ Shane.Godfrey@uct.ac.za
}

Development Policy Research Unit

DPRU Working Paper 07/130

November 2007

ISBN Number: 978-1-920055-57-8 


\section{Executive Summary}

In South Africa the central pillar of collective bargaining has historically been provided by the industrial and bargaining council systems. Statutory councils, an innovation of the new Labour Relations Act (LRA), appear to have more limited appeal. Outside the statutory system bargaining takes place at enterprise and plant levels, as well as in non-statutory centralised bargaining forums (some of which feed into the process of making sectoral determinations).

\section{Research Design}

This study aimed to build on and widen the scope of prior research on the bargaining council system by examining a number of bargaining councils in more depth as well as bargaining outside of the council system at centralised and decentralised levels. The research examined the current state of collective bargaining, the nature of existing bargaining structures, alternative models that are being developed, and the problems experienced in the current system, with a view to understanding how labour policy and regulation can better support collective bargaining. The impact of collective bargaining arrangements on small business is an important aspect of the research.

The research project, on which this paper is based, had four components. Sub-project One examined the state of the bargaining council system, to establish what threats it faces and how these can be overcome. Nine bargaining councils were selected according to a number of criteria for study. The three existing statutory councils were also investigated (two of which are registered and one of which has been established but is yet to be registered), as were some of the aborted statutory councils. The Department of Labour's policy on bargaining councils and statutory councils was also examined. The project also studied the so-called quasi-statutory centralised bargaining forums that have emerged in the security and cleaning sectors. The collective agreements reached at these forums are fed into the sectoral determination process.

Sub-project Two examined the state of collective bargaining in three sectors in which nonstatutory centralised bargaining forums exist: mining, automobile and pelagic fishing; as well as decentralised bargaining arrangements (that is, bargaining at the enterprise or plant level) in the retail sector (covered by a sectoral determination) and food manufacturing (not covered by a sectoral determination).

Sub-project Three sought to fill a gap in previous research on the bargaining council system by doing interviews with a stratified sample of owners of small businesses in order to get their perspectives on the alleged constraints that various forms of labour regulation imposed on them. 
Sub-project Four was primarily conceptual. The questions we asked in this phase sought to integrate and build on the empirical evidence generated by the three empirical sub-projects. The aim was to establish how collective bargaining could be strengthened and improved in future through policy interventions, amendments to statutes, and explorations of alternative models and practices by the parties.

\section{Historical Background and the New Legislative Framework}

The new LRA retained a voluntarist approach to bargaining in which the parties would determine their own bargaining arrangements through the exercise of power. The removal of the duty to bargaining was balanced by the introduction of a set of organisational rights and the concerted promotion of collective bargaining, particularly at the sectoral level. Underpinning collective bargaining is a protected right to strike that is given to unions that follow the statutory procedure.

Bargaining councils remain the central pillar of collective bargaining. Participation on a bargaining council remains voluntary but the Act provides a number of inducements for unions and employers to participate, in particular the ability of a council to have its agreement extended to all employers and employees within its jurisdiction. The Act requires that the parties are representative in order to have an agreement extended, but the Minister retains the discretion to extend the agreement if the parties are only 'sufficiently representative' and failure to extend the agreement would threaten bargaining at the sector level. In addition, the council must have established an independent body to hear non-party appeals for exemption, and the agreement to be extended must contain the fair criteria to be used by the independent body when considering the appeal.

The LRA introduced statutory councils to provide a compromise between the voluntarism of the bargaining council system and the compulsion that was demanded by Congress of South African Trade Unions (COSATU). In terms of the Act a statutory council can be established on application by either a 'representative' trade union or employers' organisation,that is, only one party unilaterally applies for it and this party must meet a lower representivity threshold than for a bargaining council. The drawback is a limited bargaining agenda.

The LRA also introduced the workplace forum. This institution was envisaged as a means of reducing adversarialism and promoting joint problem-solving at the workplace level, with distributive bargaining shifting to the industry level. Employers must consult the forum over proposals in respect of a wide range of issues and must disclose all information relevant to the proposals. In addition, the workplace forum has joint decision-making powers in respect of a limited list of matters. 


\section{The Current Collective Bargaining Landscape}

\section{The Statutory System}

\section{Bargaining Councils}

The number of bargaining councils has declined steeply in recent years, but the number of workers covered by bargaining councils has increased. The steep drop in the number of councils is explained by amalgamations of councils to form bigger councils and by the collapse and deregistration of some councils. It is possible that more councils will collapse in the years ahead, particularly smaller local councils.

Although the bargaining council system has proved to be very resilient, it faces some serious challenges. A major challenge is the representivity of the parties to councils for the purposes of extending agreements. The new Act provides the Minister of Labour with a discretion in cases where a party is not representative. The evidence points to the Department adopting a much stricter approach to the exercise of this discretion. By tightening up the interpretation of 'sufficiently representative' the Department aims to induce councils to solve their representivity problems. But this, in turn, is putting pressure on the council system, particularly since the Department does not appear to have any programmes to assist statutory and bargaining councils. There is arguably more the Department could be doing.

An examination of individual councils provides evidence of great stresses as well as innovation. A case study of the Cape Building Industry Bargaining Council highlights a perverse consequence of the representivity requirements of the LRA. The council underwent a remarkable turnaround under the auspices of a new CEO. It improved its financial position significantly and increased the number of registered firms and employees. However, the parties recruited very few of these firms and employees, with the result that the council became increasingly unrepresentative and the Department refused to extend its agreement.

A different dynamic emerged at the Southern and Eastern Cape Building Bargaining Council. It faced similar labour market conditions to the Cape Building Industry Bargaining Council, viz. high labour turnover, labour-only sub-contracting, and project-linked fixed-term contracts. In 2001 the employer party refused to negotiate a new agreement because it alleged that the union parties were not sufficiently representative. The employer party subsequently applied to the Labour Court to have the bargaining council wound up, but its application was dismissed. The employer party has not withdrawn from the council but refuses to negotiate in it, so the council still exists but it no longer functions as a collective bargaining forum. It is now confined to administering various social security funds, does dispute resolution functions, and performs certain secretariat functions. Bargaining takes place outside the council at two so-called voluntary bargaining groups (groups of employers that have voluntarily come together to bargain wage increases centrally with unions that are representative). Such groups are part of 
a larger scheme that the employers' organisation is proposing to the union as an alternative to the bargaining council.

The two case studies highlight the diversity in the bargaining council system. Common to both is the impact of the Department's tougher stance with regard to the interpretation of 'sufficiently representative' and that they have survived the non-extension of their agreements and seem to be on fairly firm ground financially. But, there the similarities end and generalisation becomes difficult.

The demand for greater flexibility is a key issue at bargaining councils. Most have introduced some form of variation into their agreements, usually along regional lines. The most farreaching variation has been introduced by the Leather Bargaining Council. It already has variation along sub-sectoral lines, that is, Tanning, General Goods, and Footwear. In the footwear sub-sector, which for a number of years has been under extreme pressure from imports and has experienced large-scale retrenchments and an upsurge in informal operations, employers and unions made a radical change to the collective agreement. All footwear firms are now categorised as either formal, semi-formal and informal according to eight criteria. Different wage levels (and parameters for reducing wages at company-level negotiations) apply to the first two categories, while informal firms are excluded from the agreement entirely (but must still register with the council).

Another important issue for councils is the relationship of bargaining at the council with plantlevel negotiations. It was found that the latter issue has largely been resolved in favour of agreement to bargain at the council only, that is, the agreements prohibit plant-level bargaining over issues covered in the council agreement. At the Metal and Engineering Bargaining Council the prohibition on plant-level bargaining was agreed to in exchange for the negotiation of 'actual' wages (that is, the increase is on the actual wage rather than the minimum).

The above centralisation has gone along with a perceived serious decline in plant-level bargaining within the jurisdiction of councils. This suggests that little or no productivity bargaining is taking place. Even where a framework agreement was negotiated at the central level for productivity bargaining it did not stimulate much interest at the plant-level.

Enforcement capacity varies considerably across councils. However, none of the councils saw non-registration by firms - which could be seen as a consequence of limited enforcement capacity - as a major threat and believed that enforcement was relatively effective.

Most bargaining councils are accredited with the Commssion for Conciliation, Mediation and Arbitration (CCMA) to perform dispute resolution functions, including all the councils covered in this research project. Generally, the function is performed by council staff or council staff in conjunction with a panel of outside commissioners. The Metal and Engineering Bargaining 
Council has contracted the dispute resolution function to an outside agency. All the councils indicated that dispute resolution was an important function but complained that the subsidy provided by the CCMA does not cover the cost of providing the service, which means that performing the dispute resolution function is a drain on councils' finances. Remarkably, the two building councils, one without an agreement and the other without an extended agreement, continue to provide a dispute resolution service for all firms and workers in their jurisdictions.

The LRA made provision for bargaining councils to promote and establish training and education schemes, but the Skills Development Act (SDA) effectively divorced training from councils. However, there is provision in the SDA for officials of bargaining councils to be invited onto the boards of Sector Education Training Authorities (SETAs). None of the councils in this research project had received such an invitation. Most believed that such representation would be useful, although it was stressed that the parties on councils were generally also represented on SETAs. However, training appears to have moved off the bargaining agenda.

The LRA makes provision for bargaining councils to make submissions to the National Economic Development and Labour Council (NEDLAC) over matters affecting their sectors. This provision envisages councils acting as forums for industrial policy development. None of the bargaining councils included in the research has ever made such a submission to NEDLAC.

The financial circumstances of the councils were quite healthy. This is the case even with the two building sector councils. In most cases this was not fortuitous, but was the result of positive steps taken by councils. A fairly strong pattern emerges across the councils of financial difficulties being faced about four to five years ago. This resulted in the councils restructuring and re-strategising, with the result that their financial situation has improved considerably.

\section{Statutory Councils}

Only two statutory councils have been set up and registered, viz. the Statutory Council for the Printing, Newspaper and Packaging Industry of South Africa and the Amanzi Statutory Council. Both were established through the initiative of trade unions and both are relatively stable, but neither has accomplished much so far in terms of collective bargaining. In addition, there currently exists a Statutory Council for Squid and Related Fisheries that has yet to be registered. A number of other statutory councils were established after 1996 but never lasted the course to registration, including the Statutory Council for Blood Transfusion Services, the Statutory Council for the Home Textile Industry, and the Statutory Council for the Security Industry (Western Cape). There are various reasons for their failure.

The main problem with the statutory council model is that the compulsion built into it is very difficult to implement. If, for example, employers are opposed to the council, no amount of compulsion can get them to participate and have the council registered. 
Once established, statutory councils move very slowly to expand their bargaining agendas. To date the Printing, Newspaper and Packaging Statutory Council has produced only an agreement to collect levies (which the Department of Labour has surprisingly refused to extend). Therefore, it currently functions primarily as a dispute resolution agency. The Amanzi Statutory Council, which covers the thirteen water boards established in terms of the Water Services Act, has produced agreements dealing with levies, the outsourcing of the dispute resolution function to the South African Local Government Bargaining Council, and organisational rights. The union wants to bargain wages and conditions at the council but for various reasons there is strong opposition from the employers. At both councils the unions remain committed to transforming them into bargaining councils.

The Department of Labour does not have a dedicated strategy to promote statutory councils or overcome some of the snags in the model, although various ideas are being debated.

\section{Quasi-Statutory Centralised Bargaining}

Centralised bargaining has emerged in two service sectors, security and cleaning. Larger employers in the sectors have agreed to central bargaining in an effort to restrict undercutting. In both instances collective bargaining takes place in a forum constituted in terms of the draft constitution of a yet to be established bargaining council. In both cases the main reason a bargaining council has not been established is that unions do not represent anywhere near 50 per cent of the employees in the sector, which means an agreement reached by the proposed bargaining council would not be extended to non-parties (in conformity with the stricter approach by the Department of Labour to extensions). As an alternative to the mechanism of extension, when the bargaining forums reach agreements the parties have asked the Minister of Labour to issue sectoral determinations giving effect to them.

The limitations to these arrangements became apparent in 2006, because in the cleaning sector the parties were unable to reach an agreement, even after a protracted strike, but the Minister went ahead and issued a determination. Employers are seeking to review the Minister's action in the courts. In the security sector, after what was probably the bloodiest strike in South Africa's labour history, a settlement was eventually reached. The Minister has been asked to issue a sectoral determination giving effect to this agreement.

At present the parties in both sectors are not sufficiently representative to establish councils. Small employers, located mainly in outlying areas, are probably the only constituencies that would be opposed to the establishment of councils, because many of these employers do not comply with the sectoral determination and are generally getting away with it. By contrast, the Contract Cleaning Bargaining Council in KwaZulu-Natal was perceived as relatively effective in enforcing compliance. 


\section{Small Firm Perceptions of Bargaining Councils and Other Labour Regulations}

Twenty-five in-depth interviews were conducted at small businesses (defined as firms with less than twenty employees) in order to access perceptions of bargaining councils and other types of labour regulation. Various points of similarity and difference emerged when comparing these perceptions.

Across all the firms respondents' knowledge of labour legislation and other labour regulations was generally poor. However, it was clearly better amongst those respondents covered by bargaining councils, both in terms of knowledge of legislation and the relevant bargaining council agreements. This was mainly because of the more frequent inspections and closer monitoring done by councils, as well as councils' accessibility in terms of advice and assistance. (The Department of Labour, by contrast, came in for a great deal of criticism from respondents regarding its accessibility and performance in response to enquiries.) Respondents covered by a sectoral determination or only by the Basic Conditions Employment Act (BCEA) had poor or very poor knowledge of labour regulations. Where there was knowledge it was usually restricted to payments that needed to be made,that is, in terms of Compensation of Occupational Injuries and Disease Act (COIDA) and the Unemployment Insurance Act (UIA).

Contradictions frequently emerged in the answers given by individual respondents. This was the result of the poor knowledge most respondents had of labour regulations. The implication is that owners and managers do not systematically consider or measure the impact of labour regulations on their firms. This often led to contradictions when questions were asked about costs or benefits, or alternative regulatory regimes. The poor knowledge and contradictions raise questions about the reliability of the findings of large-scale questionnaire surveys of employers.

With regard to the costs of labour regulation, respondents covered by bargaining councils focused much of their criticism on council benefit funds. Interviewees complained about the added cost of the benefit fund contributions, but many also alleged that the benefits workers received from the funds were extremely poor and/or it was sometimes difficult for workers (or their dependants) to access their benefits.

One of the most surprising findings was the strong criticism of poor enforcement. It suggests that the extension of minimum standards to all firms is not something sought just by large party employers of councils. Small non-party firms registered with councils are just as concerned that their competitors are covered and made to comply with minimum standards. In fact, such firms appear to be more at risk from competition from small unregistered firms. Hence, the serious concern that emerged over the ability of councils to police their agreements. In effect, respondents were saying that they did not have a major problem with councils but as long as 
councils ensure that all firms comply with their standards. This perception also emerged in the interviews with small firms covered just by the BCEA.

Some respondents believed that labour regulations had little impact on their firm and did not influence decisions about employment. Most, however, stated that labour regulations did impact on such decisions. But it is clear that labour regulations were only one of a number of factors that they took into account when deciding on employment levels. Labour regulations certainly did not create an absolute constraint regarding employment. A number of respondents had, for example, increased employment since establishing their firms. Further, where employment had decreased it was usually for reasons other than labour regulations. Almost every respondent identified a number of other factors as more threatening to their firms than labour regulations.

A number of respondents acknowledged that labour regulations had certain benefits. These benefits can, in the main, be categorised as setting a lower limit to competition on labour costs that gives firms greater stability and provides for sound industrial relations. A further aspect is that firms do not have to negotiate directly with unions. Furthermore, every respondent agreed that labour regulation was necessary: there was consensus that there had to be a floor of rights and standards. There was also considerable support for bargaining councils, the form of regulation that generally sets the highest labour standards. On the other hand, there was also a plea for a more flexible form of regulation, one that is more sensitive and responsive to the concerns of small firms. This was a plea that also arose at firms not covered by bargaining councils. What is surprising is that small firms do not appear to be aware of the mechanisms in the legislation providing flexibility.

The most obvious mechanism is the exemption or variation system. Earlier research has shown that the bargaining council exemption systems are working relatively well. Yet none of the respondents appeared to see applying for an exemption as a practical option. In part this flows from ignorance regarding regulations. But this is probably not the only explanation and more research needs to be done to establish why the mechanisms in the legislation designed to achieve flexibility are not being used (while employers continue to make allegations about the negative impact of labour legislation).

The second mechanism for achieving flexibility is for firms to participate in councils via membership of employers' organisations. But the interviews indicate that small firms are not pursuing this option. The main reason appears to be that they do not place much faith in the existing employers' organisations: they are either not aware of them, have no interest in participating in them, or have been put off by them. Employers' organisations need to be examined, particularly with regard to what they need to do to make themselves more attractive to small firms. 


\section{The Non-Statutory System of Collective Bargaining}

\section{Non-Statutory Centralised Bargaining}

Two major industries are covered in full or in part by non-statutory centralised bargaining arrangements: mining and automobile manufacturing. The pelagic fishing sub-sector also has a non-statutory centralised bargaining forum.

\section{Mining}

The centralised bargaining forum in the mining industry exists and operates by virtue of agreements between the participants and established practice. The forum covers only members of the Chamber of Mines in the gold and coal mining sectors. Most of the gold and coal companies that are not Chamber members are covered by firm or mine-level collective agreements, as are companies in the diamond and platinum sectors.

A host of unions are active in the mining industry and a lot of them have recognition agreements with specific mining firms, but the Chamber engages in bargaining with only four unions: National Union of Mine Workers (NUM), United Association of South Africa (UASA), Solidarity and the South African Equity Workers' Association (SAEWA). NUM is by far the largest and most representative of the unions.

There are three bargaining units: 'category 3 to 8 employees', 'miners and artisans', and 'officials'. The first category is numerically the largest bargaining unit. Shifts have taken place with regard to the levels at which bargaining takes place for the different bargaining units. Some time ago bargaining for the 'officials' category decentralised to mine level and the 'miners and artisans' category was going the same way. But this process was reversed in 2005 when it was agreed that bargaining for all the bargaining units would be merged and would be located at the central level. However, at the same time the gold and coal negotiations were split into separate forums.

As in other sectors, mining companies do not want to bargain wages at more than one level. In 1996 two-tier agreements were concluded with all the unions that stipulated that bargaining over issues that have direct cost implications (for example, wages and conditions of employment) must take place at the Chamber level, while bargaining on organisational, operational and workplace issues is at mine or company-level. However, increasingly the bargaining forum has ceased to be a structure within which the employers conclude a single substantive agreement with majority unions in respect of the bargaining units. The de facto situation is that the Chamber has often provided a forum in which its members reach separate or individual deals with union parties, particularly in respect of wage rates. Accordingly, the agreements frequently reflect different wage rates and other conditions for different 
companies, although they are negotiated at the central forum. In addition, framework agreements are often agreed to at the central level which set parameters for negotiations at mine or company level.

The above has been criticised for fragmenting bargaining, making it complex, protracted and confrontational. But the Chamber argues that a 'one size fits all' approach is not appropriate. The flexibility that the system permits is therefore seen as an advantageous feature by employers.

Bargaining has produced many collective agreements as well as a host of other initiatives to address wider socio-economic and industry concerns. Productivity bargaining, however, has not been successful. A productivity agreement was negotiated in 1997 but the Chamber argues it has never been effective and there has been unhappiness on both the employer and union side about it. Initiatives by employers to introduce profit-sharing or gain-sharing agreements have also been unsuccessful.

Since 2003 a process to establish a bargaining council for the mining industry has made slow but steady progress. The Chamber has prepared a document that identifies critical issues that need to be agreed upon, including the scope of the council, the extension of agreements to non-parties, protection of the interests of small and medium employers, and the exemption system. The scope of the proposed council is a particularly thorny issue, that is, will it include the diamond and platinum sectors, how far down the pipeline will it stretch, and does it cover the sub-contractors in the industry?

\section{Automobile}

Labour relations in the automobile industry were turbulent in the 1980s. But in 1990 the National Bargaining Forum (NBF) was established. It was initially not very stable and bargaining continued to be highly adversarial, but over time the parties began to fashion sophisticated collective agreements with joint commitments to amongst other things the longterm growth and viability of the industry and the protection of jobs.

There are two parties to the NBF: NUMSA and AMEO (Automobile Manufacturers Employers' Organisation) - comprising the seven OEMs (Original Equipment Manufacturers)in the country. This means that all the employers in the sector are represented on the NBF and its agreements bind the whole sector. NUMSA represents the vast majority of workers. The NBF exists just for collective bargaining. Participation is voluntary, it does not have a constitution, and it has few rules and formalities. It was formed through the power of NUMSA and that is how the forum is maintained.

In 1995 the NBF reached a groundbreaking agreement: it was its first three-year agreement; it was designed to put an end to the 'apartheid wage gap'; it regulated pay for skills acquired 
via training and recognition of prior learning; the parties committed themselves to improving operating efficiency, productivity, skills and quality of working life; to reschedule and recover lost production through strike action; to reduce absenteeism, inventory and waste; and to raise quality and develop people. The growing maturity of the bargaining relationship did not eradicate adversarialism: the wage negotiations in 1994, 1995, 1998 and 2001 all resulted in strike action.

The sophisticated agreements being reached by the NBF were matched by new initiatives and agreements at the enterprise and plant level to build better relationships and produce better performance.

The most interesting feature of the NBF's agreement is the provision for payment for skills acquired (rather than skills used), which allows workers to move up to grade four (of seven grades for weekly-paid workers) by acquiring additional skills even though they remain in the same job. A further feature is the Work Security Fund, which provides training in order to re-skill employees who lose their jobs as a result of major retrenchments. The agreement effectively prohibits dual-level bargaining, although there is provision for the negotiation of incentive schemes at plant-level and guidance is given as to how such negotiations should take place. There is also provision for the negotiation of a range of variations at plant-level within parameters set by the NBF agreement

The achievements of the NBF suggest a long future, but there are potential threats to its stability. Both parties express some ambivalence about the NBF. NUMSA want to create a mega bargaining council, within which the automobile sector will be a chamber. Failing that, the union would like to establish a bargaining council for the automobile sector that would incorporate the automobile components sector. Employers seem to favour greater decentralisation of bargaining, at least in the long-term. They are dissatisfied with the way that the NBF distances negotiations from the shopfloor and performance of individual firms. Whether these preferences will be achieved remains to be seen: there are high risks for both parties in destabilising the NBF.

\section{Pelagic Fishing}

The centralised bargaining forum for the pelagic fishing sector is at least 30 years old. The union party is Food and Allied Workers Union (FAWU) and the employer party is the South African Pelagic Fish Processors Association (comprising all but one of the major pelagic fish processors). FAWU represents about 70 per cent of the workers covered.

The forum is activated to bargain once a year over wages and conditions of employment, and deals with other issues during the year as and when they arise. Whatever is dealt with in the agreement cannot be negotiated at firm level. Most of the firms have negotiated social security benefits such as provident fund, medical aid and housing schemes at the firm level. Any 
additional issues will generally be bargained at firm-level. A framework for productivity bonuses is in the centralised agreement but the details are negotiated at the plant level.

If a firm is not able to pay the wage increase that is being offered it can step outside the forum. It will then negotiate with FAWU at plant-level. This might take place for one or two years, but generally once the firm is over its problem it will come back into the forum.

FAWU has been pushing for about a decade for the establishment of a bargaining council for the whole fishing sector. Some years ago a bargaining council was established for the fishing industry but it covers only sea-going employees in the hake sector. FAWU is now on the council and its strategy is to expand its scope and pull the pelagic sector into a separate chamber. Employers are resistant, seeing little reason why the existing centralised bargaining forum should be replaced. The main advantage of a council would be to extend the agreement to the small firms in the sector, but these firms are not a competitive threat to the big firms, and make up only about 10 per cent of the sector. Further, many of the small firms adopt the forum's agreement, either voluntarily or at the instigation of FAWU.

\section{Non-Statutory Decentralised Bargaining}

\section{Retail}

Historically bargaining in the retail sector has been with individual firms, with the remainder covered by a wage determination. There has been little change: currently bargaining takes place at either the national company-level, regional level or store level, and unorganised firms are bound only by the sectoral determination.

The South African Commercial, Catering and Allied Workers' Union (SACCAWU) estimates that its collective agreements cover about 150000 employees in the sector. The handful of much smaller unions does not add a significant number to this figure. This estimate means that bargaining covers only about 5 per cent of the sector (or about 8 per cent of formal employment). The reason for the limited bargaining coverage is the low level of unionisation in the sector. Organisation is difficult because there are hundreds of retail stores, most of which are very small; there are numerous informal retail operations; and where larger companies exist they have stores spread across the country. Given the way that the LRA defines a workplace, organising and getting recognition in the sector is immensely difficult. This makes the possibility of centralised multi-employer bargaining remote.

SACCAWU is currently bargaining at 32 national groups, at approximately 250 medium-sized firms, and at 150 small firms. The national groups are the most important sites for collective bargaining and include Pick n Pay, Shoprite Checkers, Spar Warehouses, Mass Discounters, Clicks (and Discom), Truworths, Foschini, and JD Group. No other unions of any significance are recognised at these firms. 
Almost all the abovementioned firms bargain at the national level for the entire group (the exception is Spar). However, most of the retail firms exclude what they see as independent operations and franchise stores (for example, Pick $n$ Pay does not bargain for the approximately 150 Pick n Pay Family Stores that are franchises). Subject to the above exclusions, the retail firms are strongly in favour of national company bargaining. In fact, most major retailers do not provide scope for regional or store-level bargaining in their recognition agreements with SACCAWU.

The use of casuals has been a feature of the retail sector and over the last decade retail firms have employed more and more people on a casual basis. Sectoral Determination No. 9 categorises most of these workers as flexi-timers and its provisions cover them, but some retail firms have strongly resisted the inclusion of flexi-timers in the bargaining unit. SACCAWU has committed itself to organising and including flexi-timers in all its bargaining units, but flexitimers are difficult to organise, and as their numbers increase they put downward pressure on the job security and conditions of permanent workers. Many retailers, on the other hand, believe that the sectoral determination has largely resolved the problem of casualisation by regulating it. It also seems that the introduction of the sectoral determination has influenced some retailers to include flexi-timers into the bargaining unit. But some retailers are holding back and are offering the inclusion of flexi-timers into the bargaining unit only in return for greater flexibility in the arrangement of hours of work.

Externalisation is also evident in the sector. Franchising is a growing trend and many large retailers have outsourced the merchandising function. Organising workers at merchandisers is difficult for a union, although it seems they have succeeded at the major merchandisers in the industry. The scope of Sectoral Determination No. 9 also includes merchandising. Another example of externalisation is the use of labour brokers. It seems that this is limited in the retail sector and is directed mainly at the distribution centres, which threatens union organisation because such centres are generally union strongholds.

The retailers generally place no limits on the bargaining agenda but it seems to be relatively easy for management to push issues they do not want to negotiate onto a secondary agenda and then to roll these over from year to year. The topics of bargaining therefore appear to be fairly standard at most retailers, although at the bigger retailers a wider range of issues is covered. In the case of Pick ' $n$ Pay this is probably because of a desire to go beyond the conventional bargaining relationship and develop something closer to a strategic partnership. Pick ' $n$ Pay is also noteworthy in that it explicitly feeds productivity and training issues into collective bargaining. Most of the other retailers have Employment Equity and Skills Development committees that are separate from the bargaining forum. Training and equity are consulted over in these committees, but it seems without a great deal of involvement by the union. This makes it difficult to link skills acquisition and new grading systems with wage bargaining in a way that would create an incentive for workers to upgrade their skills. 
SACCAWU believes that a bargaining council is vital for the retail sector. The casualisation of workers and franchising is undermining organisation and collective bargaining. A council would maintain labour standards for workers in the face of these trends. But there was strong consensus amongst major retailers that they would not agree to centralised multi-employer bargaining in the sector, one of the main reasons being that unions are not sufficiently representative.

\section{Food Manufacturing}

There is a fairly long history of union organisation in the food manufacturing sector, as well as centralised bargaining in a variety of forums, either industrial councils, multi-employer forums, or at national level for a large company. However, industrial councils had a chequered history in food manufacturing. Most of these collapsed in the 1980s. Now bargaining councils exist only in sugar manufacturing and for grain co-operatives. There are also only two multi-employer forums left in the sector, in the fruit and vegetable canning sector and the pelagic fishing industry.

Bargaining at big corporate groups has tended to decentralise, that is, negotiations for different divisions of large groups that are located in different sub-sectors generally takes place separately. For example, within the Tiger Brands group collective bargaining for milling and baking takes place separately, as do negotiations for its fruit canning and jam manufacturing operations. Centralised bargaining within corporate groups also appears to be premised on the employer's conception of their core business. The level at which bargaining takes place remains a contested issue at a number of companies in the sector.

The agreements that emanate from such negotiations are generally quite simple, particularly when compared to the more complex agreements that bargaining councils publish.

There is little impetus toward greater centralisation of bargaining. In fact, the centralised bargaining that does exist (for example, in the fruit and vegetable canning sector) has shrunk in scope. However, FAWU has raised the possibility of establishing an all-encompassing bargaining forum for food manufacturing as a whole. This does not appear to be a realistic prospect. Probably the best chance for a bargaining council would seem to be in a sub-sector such as beverages and brewing, where there are relatively few major employers. 


\section{An Analysis of the Legislative Framework for Collective Bargaining and Policy Recommendations}

The Scheme for Collective Bargaining in the New LRA has not worked:

1. Trade union membership has declined sharply, particularly outside the public sector (Du Toit et al., 2006: 42-43). Furthermore, the decentralisation of production and shift to services has made union organisation extremely difficult given the current definition of 'workplace' in the LRA.

2. Firm and plant-level bargaining is in decline, and seems to have largely disappeared within the jurisdictions of bargaining councils. This strongly suggests that organisational rights have not been an adequate substitute for the duty to bargain.

3. The jury is still out on the state of the bargaining council system. The number of councils is sharply down but the number of employees covered has increased. There are other positive developments in the system but it also faces some serious threats. However, the changes introduced by the LRA do not appear to have assisted the system very much. The Act certainly does not appear to have promoted bargaining at the central level or fused the fragmented system of bargaining councils into a more coherent whole.

4. Our interviews at small firms reveal that a major concern of many small businesses registered with councils is not the extension of the agreement but the fact that the council is not enforcing the agreement effectively. Furthermore, the opposition to bargaining councils and other labour market regulations is often coloured by a great deal of ignorance. One must nevertheless take account of the opposition of the small business lobby to the extension of bargaining council agreements. While some bargaining councils have become more sensitive to small business concerns, it is clear that the requirement in the LRA that councils must provide for representation of small and medium enterprises has not been effective.

5. The provision for statutory councils has not been successful and must be rigorously re-examined. The system must be modified or a more viable alternative should be developed. At this point, however, there does not seem to be much interest in re-visiting the statutory council model. 
6. Articulation between firm or plant-level bargaining and bargaining councils is not working. The prevailing trend is for bargaining councils, at the instigation of employers, to prohibit dual-level bargaining. So, rather than bargaining councils fashioning innovative agreements that provide scope for firm or plant-level over certain issues or within certain parameters, they are becoming proponents of one-level bargaining.

7. Workplace forums as they are currently envisaged in the LRA are a dead duck. In the light of the decline in firm and plant-level bargaining a decision needs to be made about the appropriate vehicle through which engagement can take place at this level, particularly with a view to supplementing centralised bargaining. This endeavour will have to deal with the EEA and SDA, because the effect of the employment equity and skills development committees set up in terms of these statutes has been to divorce grading and training issues from the bargaining agenda. These issues are however critical if one wants to link skills to rewards.

8. The 2006 security sector strike was probably the bloodiest in South Africa's history and has contributed to a rising trend in industrial action. This suggests that the new LRA has not significantly reduced adversarialism, or intimidation and violence.

In the light of the above, the question one must ask is whether to persevere with the framework provided by the LRA for collective bargaining because it is in principle sound? Or does one need to re-think the framework given the changes that have occurred in the labour market over the last decade? We are unequivocally of the latter school.

\section{Policy Recommendations}

Two scenarios are put forward. The first, more limited scenario, proposes that the Department of Labour must be more proactive in supporting bargaining councils. It can develop programmes to support and assist bargaining councils, disseminating best practices and coordinating systems and resources. Furthermore, the National Productivity Institute should be tasked with assisting councils and the parties to councils with productivity bargaining. The Department's more proactive role should not be limited to support for the bargaining council system. It needs to also give attention to those sectors without a tradition of union organisation and collective bargaining, where non-standard employment and informalisation are prevalent.

The Department also needs to re-visit its approach to the representivity threshold for extending agreements. However, councils can do their bit to increase their representivity by the simple expedient of incentivising participation. Councils must offer benefits that are only available to parties, for example, prohibitions on firm or plant-level bargaining over issues in main agreements should not be extended. Similarly, benefit fund agreements should not be extended. If the firm and employees want to access these funds then they should join the 
party employers' organisations and unions. In addition, the subsidy for dispute resolution must be increased, and councils should not be obliged to provide dispute resolution for non-parties where their agreement has not been extended.

The second scenario proposes more extensive changes to the current system. First, the duty to bargain, enforceable by the Labour Court, should be reintroduced. This would mean dropping organisational rights from the statute and probably mean revisiting the definition of 'workplace'. The problem of the level at which to impose the duty can be dealt with by providing that the Labour Court can make an 'order' recommending to the parties the level at which bargaining should take place. Should an employer refuse to follow such an order the union or unions can resort to power.

There should, however, be exceptions to this general rule. First, to encourage framework agreements that set only a minimum set of conditions and allow for dual bargaining (including productivity bargaining), the LRA could impose a duty to bargain at a bargaining council where the council can show that it has a framework agreement in place that provides only for minimum conditions.

A second exception would be where the employer falls within the jurisdiction of a statutory council. In such a case the Labour Court should be able to order the employer to bargain in the council. In other words, we propose that statutory councils are retained but with the added support of a judicially imposed duty to bargain.

At the workplace level it is essential that a vehicle is developed for the firm or plant level that can fashion productivity agreements, build workplace democracy, and reduce adversarialism. Workplace forums should be made compulsory for all firms with 50 or more employees. However, the statute should limit their compulsory powers to information sharing, with the proviso that sufficiently representative trade unions can upgrade the powers of the forum to consultation and joint decision-making. For firms in the 20 to 30 worker range, a majority of the workers located at the workplace should be given the power to trigger a workplace forum. Importantly, the latter threshold of twenty to thirty workers should include the employees of the firm and all other workers at the firm,that is, workers supplied by contractors or labour brokers. Furthermore, funds should be accessed from the National Skills Fund and from SETAs for a training programme for representatives on workplace forums.

In addition to the above, the LRA, Employment Equity Act (EEA) and SDA need to be reexamined to ensure that there are no obstacles in the way of creating a nexus between grading systems, training, and productivity schemes in order to incentivise skills development and improved performance. 


\section{Acknowledgement}

This report was compiled for the Department of Labour and funded by the DFID Employment Promotion Programme managed by the DPRU.

The authors would like to thank all the interviewees for their participation in this research as well as the bargaining council officials, managers and trade unionists who provided us with copies of collective agreements. Needless to say, the research would not have been possible without their co-operation and assistance.

Development Policy Research Unit Tel: +27216505705

Fax: +27216505711
Information about our Working Papers and other published titles are available on our website at: http://www.commerce.uct.ac.za/dpru/ 


\section{Glossary}

\begin{tabular}{|c|c|c|}
\hline AMEO & - & Automobile Manufacturers Employers' Organisation \\
\hline BCEA & - & Basic Conditions Employment Act \\
\hline CBIBC & - & Cape Building Industry Bargaining Council \\
\hline CCMA & - & Commssion for Conciliation, Mediation and Arbitration \\
\hline CEO & - & Chief Executive Officer \\
\hline CEPPWAWU & - & $\begin{array}{l}\text { Chemical, Energy, Paper, Printing, Wood and Allied } \\
\text { Workers' Union }\end{array}$ \\
\hline COIDA & - & Compensation of Occupational Injuries and Disease Act \\
\hline COSATU & - & Congress of South African Trade Unions \\
\hline DoL & - & Department of Labour \\
\hline EEA & - & Employment Equity Act \\
\hline EPAMA & - & Eastern Province Automobile Manufacturers Association \\
\hline FAWU & - & Food and Allied Workers Union \\
\hline ICA & - & Infrastructure Consortium for Africa \\
\hline JAMAFO & - & Joint Affirmative Management Forum \\
\hline LRA & - & Labour Relations Act \\
\hline MBA & - & $\begin{array}{l}\text { Eastern Cape Master Builders and Allied Industries } \\
\text { Association }\end{array}$ \\
\hline ME & - & Mercedes-Benz South Africa \\
\hline
\end{tabular}




\begin{tabular}{|c|c|c|}
\hline MERSETA & - & $\begin{array}{l}\text { Manufacturing, Engineering and Related Services Sector } \\
\text { Education and Training Authority }\end{array}$ \\
\hline MIDP & - & Motor Industry Development Programme \\
\hline NBF & - & National Bargaining Forum \\
\hline NCCA & - & National Contract Cleaning Association \\
\hline NEDLAC & - & National Economic Development and Labour Council \\
\hline NNC & - & National Negotiating Committee \\
\hline NUM & - & National Union of Mine Workers \\
\hline OEMs & - & Original Equipment Manufacturers \\
\hline PIFSA & - & Printing Industries Federation of South Africa \\
\hline PPWAWU & - & Paper, Printing, Wood and Allied Workers Union \\
\hline RA & - & Retailers Association \\
\hline SAAWU & - & The South African Association of Water Utilities \\
\hline SACCAWU & - & $\begin{array}{l}\text { South African Commercial, Catering and Allied Workers' } \\
\text { Union }\end{array}$ \\
\hline SAEWA & - & South African Equity Workers' Association \\
\hline SALGBC & - & South African Local Government Bargaining Council \\
\hline Samcor & - & The South African Motor Corporation \\
\hline SAMWU & - & South African Municipal Workers Union \\
\hline SASCA & - & South African Sub-Contractors' Association \\
\hline
\end{tabular}




\begin{tabular}{|c|c|c|}
\hline SASOL & - & $\begin{array}{l}\text { Originally - Suid Afrikaanse Steenkool en Olie } \\
\text { (South African Coal and Oil) }\end{array}$ \\
\hline SATAWU & - & South African Transport and Allied Workers Union \\
\hline SATU & - & South African Typographical Union \\
\hline SDA & - & Skills Development Act \\
\hline SETAs & - & Sector Education Training Authorities \\
\hline SEWA & - & Self-Employed Women's Association of India \\
\hline SEWU & - & Self-Employed Women's Union \\
\hline TBVC states & - & former Transkei, Bopuphatswana, Venda, and Ciskei \\
\hline the Department & - & Department of Labour \\
\hline the Minister & - & Minister of Labour \\
\hline TSAM & - & Toyota South Africa Motors \\
\hline UASA & - & United Association of South Africa \\
\hline UIA & - & Unemployment Insurance Act \\
\hline UIF & - & Unemployment Insurance Fund \\
\hline VBGs & - & voluntary bargaining groups \\
\hline
\end{tabular}




\section{Table of Contents}

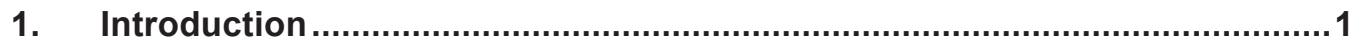

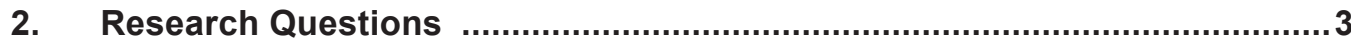

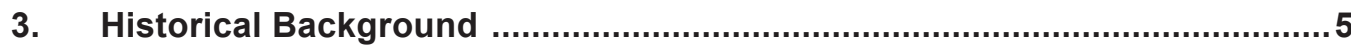

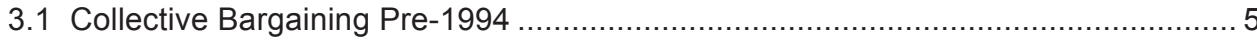

3.2 The Collective Bargaining System that Emerged Post-1994 ................................. 8

4. The New Legislative Framework for Collective Bargaining ......................12

5. The Current Collective Bargaining Landscape .......................................15

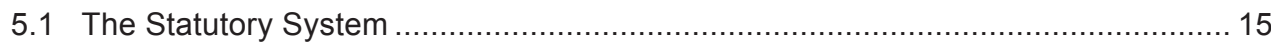

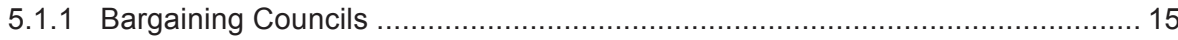

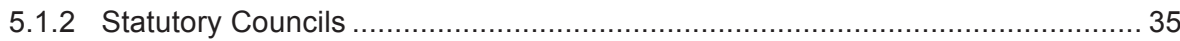

5.1.3 Quasi-Statutory Centralised Bargaining: Contract Cleaning and Security ......... 44

5.2 Small Enterprise Owners' and Managers' Perceptions of Labour Statutes, Bargaining Councils and Sectoral Determinations ............................................................... 46

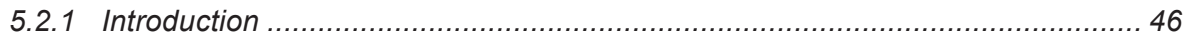

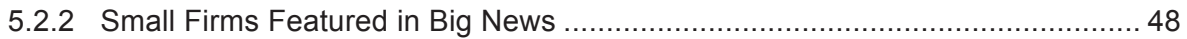

5.2.3 Small Firms Registered with Bargaining Councils ....................................... 52

5.2.4 Small Firms Regulated by a Sectoral Determination .................................... 55

5.2.5 Small Firms Regulated only by the BCEA.................................................. 57

5.2.6 Comparative Analysis of Small Firm Interviews ......................................... 59

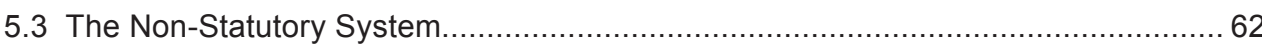

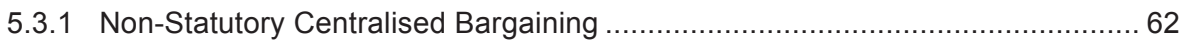

5.3.2 Non-statutory de-centralised (single-employer) bargaining ............................. 83

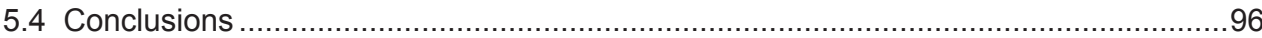

6. An Analysis of the Legislative Framework for Collective Bargaining in the

Light of the Empirical Evidence.................................................................99

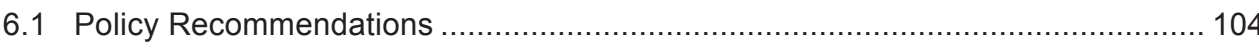

7. References....................................................................................... 108

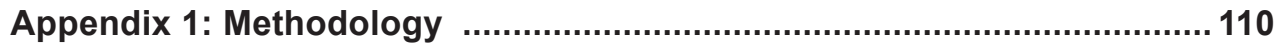

Appendix 2: A Critique of Large-Scale Surveys ................................... 113 


\section{Introduction}

Collective bargaining lies at the heart of any industrial relations system. In South Africa collective bargaining has particular importance because it is the mechanism through which 'regulated flexibility' will be achieved. In other words, the ability of collective bargaining to set wages and conditions that balance employees' needs with those of employers is critical for the ability of the new labour relations system to balance the imperatives of equity and economic development.

In South Africa the central pillar of collective bargaining has historically been provided by the industrial and (more recently) bargaining council system. Statutory councils, an innovation of the new Labour Relations Act (LRA), appear to have more limited appeal. Outside the statutory system, however, bargaining takes place at enterprise and plant levels, as well as in nonstatutory centralised bargaining forums (for example, gold and coal mining, and automobile manufacturing).

Despite the importance of collective bargaining, both in terms of its industrial relations and its economic development implications, the system in South Africa has not been well researched. Recent studies have shed some light on the bargaining council system (Godfrey et al, 2006; Holtzhausen and Mischke, 2004; Icharem, 2004), but little is known about developments taking place in company and plant-level bargaining. The lack of research extends to the outcomes of bargaining. There is very little information available about the wage rates that are being bargained at many company and plant-level bargaining forums. ${ }^{1}$ Also, we have only anecdotal evidence about the outcomes of collective bargaining in respect of other conditions of employment such as hours of work, etcetera.

This study aimed to build on and widen the scope of the research already undertaken on the bargaining council system, examining additional questions in respect of the bargaining council system, as well as researching collective bargaining outside of the bargaining council system at centralised and decentralised levels. The impact of collective bargaining arrangements on small business is an aspect of the research but is not its primary focus.

The thrust of the research project was forward-looking. In other words, it was about examining how labour policy and regulation can better support collective bargaining and different types of bargaining structures. This conceptual orientation, however, had an empirical base. So, empirical research was used to examine the current state of collective bargaining, the nature of existing bargaining structures, alternative models that are being developed, and the problems experienced in the current system. This empirical base then informed the conceptualisation of

1 The Labour Research Services AWARD wage database is the most useful resource in this regard but is by no means comprehensive. 
the sorts of legislative changes and policy inducements that could be used to strengthen and improve collective bargaining as an institution. 


\section{Research Questions}

The very wide scope of the research ran the risk of creating a vast and unwieldy research study. To avoid this problem we divided the main issues regarding collective bargaining into three categories, each with very specific research questions. We addressed each of these categories through empirical research in the form of sector or case studies. An additional process was the analysis of collective agreements collected in the empirical phase. The empirical data and the analysis of collective agreements led to a process of conceptual analysis of the state of collective bargaining in South Africa and the possible way forward.

The three categories and examples of the research questions within each are as follows:

\section{Category 1: The State of the Bargaining Council System}

- Are there aspects of the legislative framework for bargaining councils that impede their development?

- Have any councils introduced innovations to deal with problems of representivity, nonstandard work, and getting the right balance between flexibility and protection?

- To what extent is the non-registration of firms undermining bargaining councils?

- What is the extent of forms of dependent work, such as work procured by temporary employment services and other service providers, within sectors covered by bargaining councils; what impact do these forms of work have on councils; how are councils addressing such forms of work; and how successful are they?

- Is the sectoral orientation of councils restrictive, particularly given the shift to services, and if so, how can this be overcome?

- Should councils be national, industry-wide structures?

- $\quad$ Are there problems with the statutory council model that are making it unpopular?

\section{Category 2: The State of Non-Statutory Collective Bargaining}

- What is the state of centralised bargaining outside the bargaining council system?

- What is the state of decentralised bargaining outside the bargaining council system?

- What models of collective bargaining have been developed outside of the bargaining council system?

- Is the current legislative provision for organisational rights and definition of a workplace an impediment to collective bargaining? 
- Why are parties in sectors in which there are no bargaining councils unable to or opposed to forming councils (either statutory or bargaining councils)?

\section{Category 3: Collective Bargaining and Small Business?}

- To what extent are bargaining councils having a negative impact on small business?

- Are small business and workers within sectors without councils in a better position than the position prevailing in sectors covered by bargaining councils?

The sorts of questions asked as part of the conceptual (more forward-looking) phase were as follows:

- What can be done to promote and strengthen the bargaining council system?

- What mechanisms are available to councils to increase representivity, regulate nonstandard work, and create a balance between flexibility and protection?

- Are there aspects of the regulatory framework that have held back the development of bargaining councils?

- To what extent have the parties to bargaining councils realised the full potential of these institutions?

- Are framework agreements a viable way forward for bargaining councils, and if so, what conditions must be in place?

- Can amendments be made to statutes to promote collective bargaining and effective bargaining institutions outside the bargaining council system?

- What new models of collective bargaining could be promoted?

- Are there ways in which the parties to collective bargaining can be supported by policy and programmes?

- What sort of inducements could be offered to make collective bargaining more attractive or could subsidies be used to support collective bargaining?

These four categories inform the structure of this paper, with the concluding section bringing together the main empirical findings with the conceptual analysis. 


\section{Historical Background}

\subsection{Collective Bargaining Pre-1994}

Under the dual system of labour relations that existed for much of the apartheid period collective bargaining was almost exclusively the preserve of unions representing White, Coloured and Indian workers. The latter unions were recognised by the statutory framework that governed industrial relations and bargained in institutions provided for by that framework, namely industrial councils. Very little collective bargaining took place at firm or plant-level outside the industrial council system. Black workers could form and join trade unions but these operated without legislative protection and could not join industrial councils. Collective bargaining for Black workers was therefore almost non-existent and, not surprisingly, wages and conditions of employment were extremely poor.

This changed after 1973. The strikes that erupted in and around Durban in that year gave birth to a new generation of unions, most of which were non-racial, but which in practice largely organised and represented Black workers. The new unions pioneered the negotiation of recognition agreements to secure collective bargaining and other rights at individual plants and firms. They did not have it easy: employers did everything they could to prevent the unions organising their workers, while the state sought through various means to undermine or crush them. Apartheid, furthermore, ensured that trade union organisation and collective bargaining had a political import that went well beyond shopfloor issues.

The 1970s and 1980s were turbulent decades. The rapid growth of the new unions and their success in pursuing a plant-level bargaining strategy to push up wage levels, improve employment conditions and address arbitrary disciplinary action, resulted in the state appointing the Wiehahn Commission in 1977 to investigate and report on the industrial relations system. The Commission issued its main report in 1979. This was followed by a series of amendments to the Labour Relations Act (as the Act was re-named). ${ }^{2}$ The most important amendment was to the definition of an 'employee' to remove the exclusion of Black workers, thus allowing them to join registered trade unions and be directly represented on industrial councils and conciliation boards. This change gave Black workers access to the rights in the Labour Relations Act that had hitherto been enjoyed only by unions for White, Coloured and Indian workers (Du Toit et al, 2006: 10-11).

However, the contested and highly politicised nature of industrial relations meant that amendments to labour legislation, even if they were fundamentally important, did not

$2 \quad$ The amendments were issued in the Industrial Conciliation Amendment Acts 94 of 1979 and 95 of 1980 , and the Labour Relations Amendment Acts 57 of 1981, 51 of 1982 and 2 of 1983. 
immediately solve all the problems in the system. The new unions initially rejected registration in terms of the Act, thereby excluding themselves from participation on industrial councils and conciliation boards. The rejection was partly motivated by a desire to avoid the legal controls that went with registration. It was also partly in protest at the exclusion of so-called 'non-residents' and contract workers from the definition of 'employee'. These categories included many of the members of the new unions. Resistance to these exclusions saw them removed by a further amendment to the definition 'employee' in 1981. At the same time many of the controls and obligations with which registered unions were saddled were extended to unregistered unions. ${ }^{3}$

These changes had the effect that over the next few years many of the new unions registered in terms of the Act. The unions did not, however, rush to join industrial councils. The reason lay partly with the nature of industrial councils and partly with the nature of the new unions themselves. For the most part, industrial councils were conservative institutions. The employers' organisations that participated in industrial councils were used to relatively compliant trade unions and easy deals. Minimum wages were negotiated at councils, which left room for employers to use their discretion regarding higher wages at the company and plant level. The unions on councils often had a strong craft tradition, were weak in terms of shopfloor organisation, and had become used to trading off lower wages for unskilled categories of work for higher wages for the skilled categories of work in which most of their members were employed.

The new unions had been built on the basis of strong shopfloor organisation and plant or company-level bargaining. They had been fairly successful on both of these scores, using their organised power and militancy to push wages higher than the minimum levels being set by industrial councils. The benefits of participating on an industrial council were therefore not immediately apparent. A union's power would be diluted because it would be removed from the shopfloor and would be only one of a number of (established) trade unions on the employee side of a council, most of which would have interests inimical to those of the new union. It made far more sense for the union to bargain close to its power base and focus on pushing up wages for its mainly unskilled members.

But within a few years circumstances had changed and industrial councils began to look much more attractive. For a start, many of the new unions had become significantly bigger. This meant that they could join councils and in most cases dominate the employee side of the council. The power they could now wield enabled them to push up the minimum levels for unskilled and semi-skilled workers, and then have these extended throughout the jurisdiction of the industrial council. In addition, the growth of the new unions was stretching their capacity.

$3 \quad$ Labour Relations Amendment Act 57 of 1981 
Bargaining at a few centralised forums rather than at hundreds of plant and company-level forums would ease the strain on their organisational and human resources.

The joining of industrial councils by the new unions appears to have quickly had a marked impact on wage levels. ${ }^{4}$ Nicol shows that over the period 1975-1984 the median real wage for labourers covered by industrial councils rose, whereas the real median wage for artisans declined (1985: 5-8). The latter trend is also a reflection of artisans increasingly relying on their scarce skills to secure wage increases rather than trade union negotiations. Actual wages for artisans were probably significantly higher than the minimums being set at industrial councils.

From about the mid-1980s the new unions, many of which had joined COSATU, increasingly shifted the emphasis of their bargaining to more centralised levels, particularly to industrial councils. It was not a smooth process. There was opposition from employers on industrial councils and resistance by the established unions. Given the voluntary nature of the industrial council system, employers could always opt out of a council, thereby threatening its existence. In fact, this strategy led to the collapse of a number of councils and de-stabilised the entire system.

For their part, unions did not help matters by insisting that they would continue to bargain at plant and company-level after joining a council. This made sense for unions; they could bargain over minimum wage levels at the council and have these extended to all workers covered by the council, and they could negotiate 'actual' wages over and above the minimum rates at the plants and companies at which they were recognised. But it made no sense for employers. If they were going to have to bargain with a trade union then they would do so once, either at a council or at the plant or company-level. Why carry on participating in a council, their reasoning went, if they were in any case going to be negotiating with the union in their plants?

The level at which bargaining took place has therefore been a key industrial relations issue in South Africa since the emergence of the new unions after 1973. It has been as much a feature of collective bargaining in this period as has been the substance of negotiations. The push by unions to raise wages, improve other conditions of employment and expand social benefits for their members was critical in addressing the distorted labour market created by apartheid. But as important was the intention to maximise the spread of such improvements by negotiating them at more centralised levels. Both goals created enormous tensions in the industrial relations system and also exposed the limitations of the statutory framework for collective bargaining. The political struggle and the active role of unions in the struggle informed and exacerbated these tensions. It was a highly volatile mix.

$4 \quad$ It should be noted that there is very little data on wages for this period. The data that is available is often not very reliable.(Standing et al, 1996: 177) The SALDRU database and the Labour Research Service data on wage settlements are the exceptions. 


\subsection{The Collective Bargaining System that Emerged Post-1994}

The transition to democracy relieved some of the tensions but did not improve the standard of living of the majority of the population, or change the demographics of the average South African workplace, or eliminate the heritage of politicised industrial relations. It also did not resolve the problems with regard to the level at which bargaining took place. But the election of the ANC in the country's first democratic elections in 1994 did open the way for a review of labour legislation. Indeed, such a review was a priority of the new government. A key aspect of the review was the collective bargaining dispensation.

The task team that was appointed to design a new industrial relations statute identified "the lack of conceptual clarity as to the structure and functions of collective bargaining" as the major problem with the 1956 LRA (Draft Negotiating Document, 1995: 121). This criticism refers mainly to the "lack of commitment to an orderly system of industry-level bargaining" that had resulted in the development of a "patchwork" system of industrial councils, and the failure of the statute to provide a legal framework for the separate system of workplace bargaining that had emerged after 1973. Further problems were the exercise of the Minister's discretion with regard to the extension of industrial council agreements and the somewhat confused jurisprudence that the Industrial Court had developed regarding the level at which to impose a duty to bargain. The task team concluded that as a result of the above problems "there is no existing statutory framework which can properly accommodate and facilitate an orderly relationship between bargaining at the level of industry and at the level of the workplace" (Draft Negotiating Document, 1995: 121).

The remaining problems identified by the task team related specifically to industrial councils. These included the criteria for the representativeness of industrial councils, the bureaucratic structure of councils, procedures for granting exemptions from industrial council agreements, and the enforcement of council agreements by criminal prosecution.

The task team considered three collective bargaining models when deliberating how to solve the above problems. The first model was one of statutory compulsion, in which there would be a duty to bargain together with statutory determination of the levels at which bargaining takes place and the issues over which parties bargained. The second model advocated a considerable degree of compulsion but proposed that it would be the judiciary that would determine the appropriate levels of bargaining and bargaining topics. The third model comprised a voluntarist system in which the parties would determine their own bargaining arrangements through the exercise of power. The latter model was probably the closest to the existing system.

The task team plumped for the third model, but it embedded the principle of voluntarism within a statutory framework that "unashamedly promotes collective bargaining". The promotion of 
bargaining aimed at the central or industry level, albeit without prescription. Its reason for rejecting the two models that entailed compulsion was that these would introduce rigidity into a labour market that needed to be able to respond to changing economic conditions:

The ability of the South African economy to adapt to the changing requirements of a competitive international market is ensured only where the bargaining parties are able to determine the nature and structure of bargaining institutions and the economic outcomes that should bind them, and, where necessary, to renegotiate both the structures within which agreements are reached and the terms of these agreements (Draft Negotiating Document, 1995: 122).

The draft Bill, therefore, retained many of the provisions of the LRA with regard to industrial councils, which the Bill proposed to re-name bargaining councils. But there were some important changes:

- Bargaining councils could be formed in the public sector or could straddle the public and private sectors

- Small business interests would need to be represented on councils

- The representativeness of councils would be reviewed annually

- A requirement for the extension of a council agreement would be the existence of an independent body to hear exemptions on grounds of undue hardship.

In addition, it would be left to National Economic Development and Labour Council (NEDLAC) to establish criteria for the demarcation of sectors. The intention was that this would allow NEDLAC to design a more coherent system of sector-level bargaining.

An important new function that bargaining councils would perform was dispute resolution within their registered scope. In order to do so the council would become accredited by the Commission for Conciliation, Mediation and Arbitration (CCMA) or would have to engage the services of an accredited private agency to conciliate and arbitrate disputes.

Instead of a duty to bargain and other forms of compulsion, the task team provided supports for collective bargaining. Key to this was a series of organisational rights, none of which was absolute and all of which would be accessible only if the union met thresholds of representativeness. The proposed rights related to:

- $\quad$ access to premises for union-related purposes

- $\quad$ the holding of meetings 
- conduct of ballots

- $\quad$ stop-order facilities

- $\quad$ time off for union activities

- $\quad$ election of union representatives

- information for collective bargaining purposes.

It was left to NEDLAC to decide the statutory thresholds for the organisational rights (or whether thresholds were necessary for certain rights). The Task Team envisaged that the social partners at NEDLAC would negotiate a balance between low thresholds, which would assist in the organisation of the unorganised, and high thresholds, which would avoid a proliferation of trade unions and provide stability for existing bargaining arrangements. However, the Bill provided that a union representing more than 50 per cent of the employees in a workplace or a bargaining council could reach a collective agreement that varied the thresholds imposed by the statute. Thereafter the new threshold would apply equally to all registered unions seeking such rights in the workplace.

Further supports for collective bargaining were provision for agency shops ${ }^{5}$, a new dispute resolution system that would use conciliation and advisory arbitration to assist parties to reach agreements, and a protected right to strike.

In line with the notion of self-regulation that informed the draft Bill, provision was made for registered unions and employers to conclude legally binding agreements that would be enforceable by arbitration rather than through the criminal or civil courts. In terms of this new scheme, trade unions, employers and employers' organisations would be responsible for the enforcement of their own agreements.

In addition, a new institution was proposed, the workplace forum, which would be separate from the collective bargaining system but would supplement that system in important ways. The mode of engagement in the workplace forum model was envisaged as joint problemsolving, and its focus would be on non-wage matters such as restructuring, work reorganisation, and the introduction of new technology (that is, issues that were not traditionally the preserve of collective bargaining). Implicit in the proposals regarding bargaining councils and workplace forums was a scheme in which adversarial bargaining over distributive issues

$5 \quad$ The Task Team feared that the closed shop was vulnerable to constitutional attack. The draft Bill therefore did not provide for a closed shop. Instead, the Task Team proposed that the provisions in the old LRA that regulated closed shops should not be repealed (in which case they remained insulated from constitutional review in terms of section 33(5) of the interim Constitution) and that industrial council agreements with closed shop provisions should remain in force until the new Constitution was finalised. The main thrust of the draft Bill therefore dealt with the introduction of agency shops, which were seen as a much safer bet under the interim Constitution. 
would be located at the industry level and co-operative engagement over issues affecting productivity and performance would take place at the workplace. 


\section{The New Legislative Framework for Collective Bargaining}

The draft Bill discussed above was the basis for public comment and negotiation between the social partners in NEDLAC. Certain of the above proposals in the draft Bill were amongst the most contentious in the latter negotiations. In the section below we briefly outline the provisions in respect of collective bargaining that emerged at the end of the negotiations and were promulgated in the new LRA.

Overall the LRA is firmly committed to the promotion of collective bargaining, particularly at the sector level. However, the new Act significantly narrowed the scope of the unfair labour practice, which had the effect of removing a judicially imposed duty to bargain. This confirmed the voluntarist foundation for the collective bargaining regime introduced by the Act. In terms of the LRA it would therefore be power that would determine the recognition of bargaining agents, the choice of bargaining levels, the scope of the bargaining agenda and bargaining conduct. ${ }^{6}$

In place of a duty to bargain is a set of organisational rights that should create the conditions for effective union organisation that will result in collective bargaining. Unions that are sufficiently representative (acting alone or jointly) are able to acquire some of these rights access to the employer's premises, stop-order facilities, the right to hold meetings and ballots, and leave for trade union office bearers - while majority unions (acting alone or jointly) can acquire certain additional rights, that is, the election of trade union representatives and the right to information for bargaining and monitoring purposes. A further aspect of the promotion of collective bargaining is that collective agreements are made legally binding and enforceable through arbitration. And, underpinning collective bargaining is a protected right to strike that is given to unions that follow the statutory procedure (Du Toit et al, 2006: 29).

Bargaining councils (the new name for industrial councils) remain as the focus of the LRA's treatment of collective bargaining. Provision is made for the registration of new bargaining councils (or the amalgamation of existing bargaining councils) by parties that are "sufficiently representative", with NEDLAC being given the task of determining the scope and area of the new council.

Participation on a bargaining council remains voluntary but the Act provides a number of inducements for unions and employers to participate. ${ }^{7}$ The most important attraction of a bargaining council is the ability to have its agreement extended to all employers and employees

6 For example, the elimination of bad faith bargaining or in response to unilateral conduct by an employer (Du Toit et al, 2006: 250-252).

7 For example, trade union parties on a council automatically receive the organisational rights of access and stop-order facilities in all workplaces in the jurisdiction of the council. For employers, there is the inducement that councils have the power to determine matters that may not be an issue in dispute for the purposes of industrial action at the workplace (Du Toit et al, 2006: 249). 
in the jurisdiction of the council. The Act requires that the parties are representative in order to have an agreement extended, but the Minister retains a discretion to extend the agreement if the parties are only 'sufficiently representative' and failure to extend the agreement would threaten bargaining at the sector level. However, in response to pressure from small business, the Act introduces further requirements for extension: the council must have established an independent body to hear non-party appeals for exemption and the agreement to be extended must contain the fair criteria to be used by the independent body when considering the appeal. ${ }^{8}$

The LRA introduced statutory councils to provide a compromise between the voluntarism of the bargaining council system and the compulsion that was demanded by COSATU. In terms of the Act a statutory council can be established on application by either a 'representative' trade union or employers' organisation. A 'representative' trade union is a registered union (or two or more acting jointly) that has as its members at least 30 per cent of the employees in the sector and area for which it wants the statutory council established. Similarly, the member firms of a 'representative' employers' organisation must employ at least $30 \%$ of the workers in the relevant sector or area. If an applicant union or employers' organisation is representative and complies with certain formalities, the Registrar of the Department of Labour must establish the statutory council. A process then follows to get other parties to participate on the council, either through agreement or appointment by the Minister, which then leads to registration of the council.

The important point to note about the establishment of a statutory council is that only one party unilaterally applies for it (for example a trade union); it therefore does not need the agreement or cooperation of the other party (e.g. an employers' organisation). Furthermore, the threshold for establishing a statutory council is 30 per cent on the part of the applicant, whereas the threshold for registering a bargaining council is that both parties (that is,. unions and employers) must be 'sufficiently representative'. ${ }^{9}$ So the statutory council model introduces a certain amount of compulsion and sets a lower representivity threshold. The drawback of a statutory council is that it has a limited bargaining agenda.

The intention of the LRA is that unions should be able to more easily establish statutory councils. Once established, bargaining will take place over a limited range of issues, but over

$8 \quad$ Research done by Butcher and Rouse suggests that the extension of agreements does not have a significant effect on labour costs for non-party firms. Using data from the 1995 October Household Survey they found that African non-union members covered by industrial council agreements earned 6-10 per cent more than unorganised African workers not covered by such an agreement. The same comparison for White workers reveals an industrial council premium of only 2-3 per cent. When union membership is included the premium for African workers rises to about 32 per cent, which the researchers conclude reflects the fact that unions for African workers are pushing up wage levels for their members through firm-level bargaining (Butcher and Rouse, 2001: 364-9).

9 The term 'sufficiently representative' is not defined in the Act, so it is not clear whether this sets a higher threshold than 30 per cent, but it is very likely that this is the case. 
time this can be expanded (provision is made for this in the Act). Agreements over these issues can also be extended to the rest of employers and employees in the relevant sector and area. As the agenda becomes wider and additional issues begin to be bargained, the stage will be set for the statutory council to upgrade to a bargaining council. The statutory council model was therefore envisaged as a stepping stone for the establishment of bargaining councils.

The LRA also introduced the workplace forum. As noted above, this institution was envisaged as a means of reducing adversarialism and promoting joint problem-solving at the workplace level, with distributive bargaining shifting to the industry level. The objective of workplace forums is to focus on issues that emphasise the common ground between management and workers rather than the differences.

A workplace forum can be established on application by a majority union (or two or more registered unions that together have a majority) in a workplace with more than 100 employees. If these requirements are met the setting up of the forum is compulsory, although there is considerable scope for managers and unions to agree on the structure of the forum and how it will function. The representatives on workplace forums are elected by all employees and must represent the entire workforce. ${ }^{10}$ Employers must consult the forum over proposals in respect of a wide range of issues and must disclose all information relevant to the proposals. In addition, the workplace forum has joint decision-making powers in respect of a limited list of matters.

10 In response to union concerns that workplace forums could undermine union organisation at firms, the Act introduced a trade union-based workplace forum which allows the applicant union to choose the members of the forum from amongst its shop stewards. 


\section{The Current Collective Bargaining Landscape}

\subsection{The Statutory System}

\subsubsection{Bargaining Councils}

The number of bargaining councils has declined steeply in recent years, but the number of workers covered by bargaining councils has increased. The sharp rise in coverage is because of the addition of the public sector councils after the new LRA. However, even if one were to exclude the employees covered by the public sector councils the total coverage of the remaining councils (that is, the private sector councils) shows an increase on earlier years: in 2004 the number of employees covered by the private sector councils only was 1282043.

Table 1: Bargaining Councils and Employee Coverage

\begin{tabular}{|c|c|c|}
\hline Year & Number of councils & Total registered employees covered \\
\hline 1983 & 104 & 1171724 \\
1992 & 87 & 735533 \\
1995 & 80 & 823823 \\
2004 & $48^{11}$ & 2358012 \\
\hline
\end{tabular}

Source: Du Toit et al, 2003: 40

There are a number of explanations for the steep drop in the number of bargaining councils. First, there have been a number of amalgamations of councils to form bigger councils. For example, the regional clothing councils and some related councils merged to form a single national clothing council. A similar process of amalgamations occurred in the textile and the local government sectors. These developments contributed to a decline in the number of bargaining councils but did not alter the number of workers covered. In other words, it is evidence of a strengthening of centralised bargaining.

Further evidence of a strengthening of centralised bargaining is the establishment of new bargaining councils. As mentioned above, after the introduction of the LRA five new bargaining councils were set up in the public sector. This added a very large number of workers to the total covered by the bargaining council system. However, a few new councils have also been established in the private sector (leaving aside the big national councils formed through the merger of existing councils). The new councils are in the chemical industry, the wood and paper sector, the fishing industry, and in the motor ferry industry. All are national councils but

11 This figure excludes six bargaining councils that were in the process of being deregistered by the Department of Labour as well as two registered councils that were defunct. Two councils that have to all intents and purposes merged have been counted as one council. 
the latter two are quite small, in terms of the number of workers covered, while the chemical council and the wood and paper council have yet to extend their collective agreements. ${ }^{12}$

The establishment of new councils, however, has not off-set the sharp drop in the total number of councils. As noted above, part of this decline is explained by the amalgamation of councils. But the other part of the decline is because of the collapse of councils. Since the new LRA was introduced a number of councils have ceased to function and have been deregistered. In the building sector, for example, most of the councils have disappeared, notably the Gauteng Building Industry Bargaining Council. There are also a number of councils that continue to exist but are on very shaky ground. The Southern and Eastern Cape Building Industry Bargaining Council is one of these. It survived an attempt by employers to have it wound up but continues to exist in something of a limbo ${ }^{13}$, it no longer functions as a collective bargaining forum and now mainly performs dispute resolution functions and administers various benefit funds. It is possible that more councils will collapse in the years ahead, particularly smaller local councils.

So, the bargaining council system faces some serious challenges. One major threat is the issue of representivity and the requirements in the LRA for extending collective agreements. The more employers and employees that do not join the employers' organisations and trade unions that participate on councils, the harder it is for bargaining councils to maintain the necessary level of representivity to have their agreements extended to non-parties (that is, the firms and employees who are not members of party employers' organisation and unions). If a council does not have its agreement extended there is a strong possibility that it will collapse in the short to medium-term. Employers that are bound by the agreement through their membership of the party employers' organisation will be undercut by non-party competitors. The obvious response of many will be to leave the employers' organisation so that they are no longer bound by the council's agreement. The logic of this process will be the eventual demise of the council.

It was noted above in Section 4 that the Task Team that produced the draft Bill that preceded the new LRA had identified the issue of representivity and the exercise of the Minister's discretion to extend agreements as two key problems with the old industrial council system. The new LRA attempted to address these problems. First, the Act introduces 'hard' measures as thresholds for representivity (as opposed to the notion of 'sufficient representivity' used in the 1956 LRA). So, the Minister may not extend a bargaining council agreement unless satisfied that after extension the majority of all employees covered are members of the party trade unions, and the members of the party employers' organisations employ the majority of

12 The wood and paper council does have an agreement in respect of a dispute resolution levy that has been extended by the Minister, but the collective agreements dealing with wages and other conditions that have been reached in its various chambers have not been extended and bind only the parties to the agreements.

13 East Cape Master Builders \& Allied Industries Association \& another $v$ Building Industrial Bargaining Council (Southern \& Eastern Cape) \& others; [2004] 4 BLLR 356 (LC). 
the employees. The section goes on to list further requirements for extension. A bargaining council agreement cannot be extended by the Minister unless he/she is satisfied that provision is made in the agreement for an independent body to hear appeals against the refusal by the council of a non-party's application for exemption or the withdrawal of an exemption by the council. In addition, the collective agreement to be extended must contain criteria that will be applied by the independent body when it considers an appeal. These criteria must be fair and promote the primary objects of the Act. Another requirement is that the terms of the collective agreement must not discriminate against non-parties.

If the above requirements have been met the Minister must extend the agreement. In other words, the Act removes the exercise of any discretion on the part of the Minister if the relevant council meets these requirements. If, however, the council does not meet the representivity requirements, the Act gives the Minister the discretion to nevertheless extend the agreement to non-parties. The Minister may do so if the parties to the council are "sufficiently representative within the registered scope of the bargaining council" and if "the Minister is satisfied that failure to extend the agreement may undermine collective bargaining at sectoral level or in the public service as a whole". The Minister therefore has a fairly wide discretion. The Act does not define what is meant by "sufficiently representative", leaving this entirely to the Minister to determine. The second criterion widens the Minister's discretion even further, given the argument - a strong one - that the failure to extend a sectoral collective agreement will almost always undermine bargaining at that level.

The actual exercise of this discretion by the Minister is not an easy matter to research. In practice, a lot of work in this regard is done first by officials of the Department. So, the request to extend an agreement and the relevant council's compliance with the Act's requirements is initially examined by officials. If there is a problem with regard to any requirement - the representivity requirements are the ones most likely to cause problems - the officials will engage with the council. This usually takes the form of referring the agreement back to the council and advising it that the Department is not going to recommend to the Minister that he extends the agreement and why this is the case. In other words, the agreement is not referred directly to the Minister for approval or rejection. The implication is that the council must sort out the problem and re-submit the agreement, in which case extension should be unproblematic. But in practice it is not easy for the parties to a council to quickly improve their representivity. So, this engagement with the Department can be protracted. Effectively the council's agreement is not being extended pending the resolution of the problem, without it yet reaching the Minister. It seems that quite often the agreement is not re-submitted.

It is not possible to put numbers to the above. We do not know how many agreements have been sent to the Department in the last year or the last two years; and we do not know how many of these have been immediately extended, how many have been extended after being referred back, how many have been referred back to the council and never been re-submitted to the Department, and how many have been re-submitted for extension and then rejected. It is 
even the case that some councils refuse to make any changes, re-submit the agreement and insist that it is referred to the Minister for his decision. At one point there were press reports that fourteen councils had been refused extensions. The Department would not confirm this figure but it was stated that if this was in fact the case then twelve of those refusals would have been referrals back to councils by officials and two of them would have been refusals by the Minister. In other words, without confirming the figure the Department indicated the sort of proportions into which referrals and refusals could be broken down. However, it was acknowledged that the Minister had refused to extend at least two agreements. These appear to be agreements that councils had insisted go to the Minister against the advice of officials.

The above strongly suggests that a stricter approach is being adopted. Although it was stated that the Department has not changed its policy regarding extensions, it was also acknowledged that it was becoming much tougher with regard to requests for extensions. For example, it was stated that if the employer or union parties have a representivity figure in the 30 per cent to 39 per cent range, then the council will definitely not get its agreement extended. Even if one of the parties fell within the low 40 per cent range the Department would be reluctant to recommend extension. It therefore appears that the Department has changed its policy on extensions in that it is adopting a much stricter approach to interpreting the requirement of parties to be 'sufficiently representative'.

One cannot say exactly what has caused this tougher approach. But a major factor must be the strong resistance many employers, particularly non-party small businesses, have to extensions. This has included a number of legal challenges to extensions. ${ }^{14}$ The Department's new approach is therefore not a case of them turning their back on centralised bargaining. On the contrary, its interpretation of the LRA is that it has a duty to encourage centralised bargaining. The problem the Department faces is that bargaining councils must have legitimacy and this is undermined by unrepresentative parties. By tightening up with regard to what is and is not 'sufficiently representative', the Department aims to put pressure on councils to try to solve this problem rather than to undermine councils. Hence, a number of councils that were interviewed mentioned the annual visits that they now have from the Department's officials at which they have strongly stressed the need for parties to be representative if the council wants its agreement to be extended.

The Department want to try to find a solution to the representivity problem. A number of ideas are being bounced around in this regard. ${ }^{15}$ One is that all 'atypical' workers are excluded from the calculation of representivity, the rationale being that 'atypical' workers are almost

$14 \quad$ Kagiso Shell v Minister of Labour; Newcastle Chamber of Commerce v Minister of Labour and the National Clothing Industry Bargaining Council; Reliff Interior \& Joinery CC v Minister of Labour and the Bargaining Council for the Furniture Manufacturing Industry (KZN); and, ITB Manufacturing v Minister of Labour and another. It is, however, not clear how many of these cases were proceeded with and how many were withdrawn or just petered out. It should be stressed that these are some of the ideas being debated and are not concrete proposals. 
impossible to organise. ${ }^{16}$ Another idea that aims at maintaining union representivity in the face of externalisation is that all workers covered by a council that are outsourced should be compelled to remain or become members of the majority party union. So majority trade unions would be able to maintain their representivity in the face of outsourcing and other forms of externalisation. Of course, this is merely a proposal for internal debate at the moment and the Department is aware of the negative side to the latter, that is, it restricts workers' freedom not to associate and would probably be open to a constitutional challenge.

The above ideas indicate that the Department is trying to grapple with this complex problem. What else does it do to encourage centralised bargaining? One strategy that the Department has considered is to use the threat of sectoral determinations to pressure employers into forming councils. The logic is that employers would prefer to negotiate wages and conditions in a bargaining council rather than have them imposed by the Minister. The problem is that there are perverse incentives if one does not pitch the standards at exactly the right level. For example, setting wages too high could undermine union organisation because the reference point for workers would become the sectoral determination rather than collective bargaining. On the other hand, setting wages too low would mean there is little or no pressure on firms to go into a bargaining council. Adding to the problem is very strong employer resistance to sectoral determination increases being based on 'actual' wages rather than minimums. ${ }^{17}$ The Department does not appear to have found a way out of this conundrum.

It is somewhat surprising, given the Department's duty to encourage centralised bargaining, that it has no other programmes to assist statutory and bargaining councils. It seems that the Department has interpreted the philosophy of voluntarism that underpins the bargaining council framework in the LRA to mean that it must adopt a hands-off approach with regard to the system, merely performing registration and administrative functions. But the absence of compulsion in the Act does not mean that the Department cannot play a proactive role with regard to bargaining councils. At present the Department is making an effort to meet with councils regularly, to brief them on developments and problems, and to discuss ideas and make suggestions. ${ }^{18}$ But there is arguably more the Department could be doing. For example, the Department could assist in disseminating best practices and systems from some of the bigger councils to smaller, less well-resourced councils. There is also other sharing of information and co-ordination of resources that the Department could initiate.

16 The deliberations of the NEDLAC task team on 'atypical' work was seen as possibly assisting the Department with regard to this proposal.

17 This opposition was sparked by the Sectoral Determination for the Domestic Sector which provided for increases on 'actual' wages. Employers argued at NEDLAC that the Minister does not have the authority in terms of the BCEA to base wage increases on 'actual' wages. It seems it was agreed that the Minister would not do so again.

18 For example, the Department has proposed that councils could cut costs by sharing some facilities and resources. Councils in a particular region could share dispute resolution facilities and smaller councils could even share enforcement personnel. 
There is also the issue of financial assistance. Bargaining councils receive a subsidy for doing dispute resolution if accredited by the CCMA. By all accounts this subsidy does not cover the costs of performing this function and dispute resolution is therefore a financial drain on councils. This needs to be addressed. By the same token, bargaining councils perform enforcement functions that would have to be done by the Department of Labour if the council did not exist. Why is it that councils do not receive some sort of subsidy for this function? This would be one way of bolstering the financial position of councils and improving levels of enforcement of labour standards.

\section{Two Case Studies: the Cape Building Industry Bargaining Council and the Southern and Eastern Cape Building Bargaining Council}

\section{The Cape Building Industry Bargaining Council}

The Cape Building Industry Bargaining Council (CBIBC) is an old, well-established bargaining council. The parties are, on the employer side, the Master Builders and Allied Trades Association (Western Cape) and the Master Builders and Allied Trades Association (Boland), and, on the trade union side, the Building Workers Union, SA Woodworkers Union, National Union of Mineworkers, Building Wood and Allied Workers Union SA, and the Building Construction and Allied Workers Union. The council negotiates wages, conditions of employment, and social security benefits (it has established a Pension Fund, a Provident Fund, a Medical Aid Fund [for artisans only], a Sick Pay Fund, and a Holiday Fund). Its agreements cover over 20000 employees and over 1000 employers in the Cape Peninsula and much of the Boland.

Some years ago the CBIBC went through a period of considerable instability. The emergence of labour-only sub-contractors had seen an upsurge in the number of employers that were not registering with the council or complying with its agreements. This had caused rumblings amongst registered firms about the feasibility of continuing to have a bargaining council. The council eventually set up a one-person commission of inquiry (comprising Prof Frank Horwitz) to investigate the situation and propose a way forward. The vast majority of respondents indicated that they wanted the council to remain. But there was general consensus that things needed to be done differently. The council needed to become more 'developmental' and more responsive to the needs of the industry. The commission recommended some changes, including that the council should become entirely voluntary (that is, it should not seek to extend its agreement) and that employers and employees should be able to select which benefit funds employees belonged to (Horwitz, 2000).

Following the commission a process was initiated to take discussions around its recommendations forward. Meetings were held with the SA Subcontractors Association, 
a new body that had emerged to represent sub-contractors and labour-only subcontractors, with a view to establishing a forum for setting wage rates for specified trades. The council also granted a blanket indemnity to all employers not registered with the council or not complying with its agreements, conditional on employers applying for indemnity and thereafter complying with a set of minimum conditions. ${ }^{19}$

Ultimately, none of the major recommendations of the commission were followed and it appears that the above process and changes had little impact. By the second half of 2003 the council was on its last legs. A number of Secretaries had come and gone in short succession, and it was calculated that the council would be bankrupt within 12 months (it had been operating at a loss for some years). Non-compliance still remained a major problem. Then, in October 2003, a new Secretary (or CEO) was employed by the council with the brief to turn it around. Within 18 months the bargaining council was in the black. A projected deficit of R2.2 million for 2004 was turned into a R600 000 surplus and by 2006 the council had a R5 million surplus. Furthermore, in a year the number of registered employers grew from 1230 to 1531 (24 per cent) and the number of registered (active) employees rose from 22823 to 28247 (23 per cent)..$^{20}$ What did the new Secretary do to achieve this success in such a short time?

First, the council increased its levy for the first time in 40 years. Second, it focussed on increasing the number of registered employers and employees, which would also improve the financial position of the council, through a variety of strategies. The starting point for the strategies was the realisation that the council could not enforce compliance by 'policing the building sites'. There were 15 inspectors to police about 57000 employees (if one included estimates of the number of employees at unregistered firms) in numerous building sites across a wide area. It was realised that this was an impossible task. The strategies were generated by creative thinking to come up with alternatives to policing (Bezuidenhout et al., 2004: 55-56).

The first strategy was to make a building contractor jointly and severally liable for noncompliance with the bargaining council's agreement on the part of its sub-contractors. This puts pressure on contractors (which are too big to avoid compliance themselves) to become part of the enforcement mechanism with regard to sub-contractors. ${ }^{21}$

19 See Building Industry Bargaining Council (Cape of Good Hope), Newsletter 3/2001.

20 See CBIBC documents entitled 'How the BIBC can assist employer and employee organisations to increase their membership' and 'The sadness of success'.

21 This logic has been followed by the South African Revenue Service (SARS). SARS was concerned about revenue that it was not collecting from small sub-contractors and labour-only sub-contractors (LOSC) in the building industry. As a result, it issued a directive that if the sub-contractor or LOSC is not registered with SARS it is the responsibility of the main contractor to deduct 10 per cent of the contract price and pay this over to SARS in respect of PAYE. So, rather than trying to get hundreds of small sub-contractors and LOSCs to register and deduct PAYE, SARS has chosen to shift the obligation to the main contractors. 
The second, and probably the most innovative strategy, was promoted under the slogan, 'Breaking the Chain of Poverty'. This strategy involved the council going to the source of building work, both on the tender side and the financing side, in order to get compliance built into the system at that point. On the one hand, the council targeted the Public Works Department, the Provincial Administration of the Western Cape, the City of Cape Town, the Construction Industry Development Council, and the National Home Builders Regulatory Council. These are the institutions that generate most building work. The aim of the strategy is to get these institutions to work only with firms that are registered with the bargaining council. On the other hand, the council also went through the same process with the major banks (via the Council of SA Bankers) and other loan institutions (Bezuidenhout et al., 2004: 55-56).

Key to the strategy was a letter from the Western Cape Regional Secretary of COSATU that asks for greater compliance in the industry and better policing on the part of the council. The letter is used by the council to endorse the 'Breaking the Chain of Poverty' campaign,,that is, it is brought out when institutions express reluctance or opposition to enforcing compliance as requested by the council. An example was the Sakhasonke Emerging Contractor Development Programme (SECDP), a joint programme of the Public Works Department and the Ministry of Finance. When it was approached, the SECDP was reluctant to agree to the request of the council. It cited the need to create jobs and assist emerging contractors as the reason. However, when the letter from COSATU was produced there was an immediate change and it signed up. The council subsequently found that 60 per cent of the builders in the programme were unregistered (Bezuidenhout et al, 2004: 55-56).

Third, the council adopted a new approach to its policing functions. Inspections are now proactive (previously the council was inspecting in response to complaints only) and plansdriven. The latter means that the council gets all the building plans each month from the various municipalities falling within its jurisdiction. A sample of the plans is selected and inspectors go out and do inspections at those building sites. They also have media-generated inspections. In this case the council scans the media for announcements of new projects and buildings. They go out and conduct inspections at these sites. A third strategy, termed 'finders and minders inspections', is to give any council staff member a R50 reward for reporting a building site that is subsequently found to have unregistered contractors or sub-contractors on it (Bezuidenhout et al, 2004: 55-56).

All the above strategies are pursued within a new approach to compliance being adopted by the council. This is termed the 'positive marketing and educational approach' and aims to prioritise voluntary compliance. The council is therefore making every effort to become user-friendly as well as to offer benefits to registered firms. The council goes out of its way to deal positively with firms that approach it. It also goes out and engages with firms. Backing up this new approach are services to attract employers to the council, including a payroll service for firms at a nominal 
fee and an employment bureau. ${ }^{22}$ The council also offers labour relations courses to employers (the aim being to prevent disputes through education), does entrepreneurial training, and holds monthly seminars on topical issues. Policing is still an important component in the strategies of the council but has become a measure of last resort (Bezuidenhout et al, 2004: 56).

What has been the outcome of this remarkable turnaround? ${ }^{23}$ Increasing numbers of previously unregistered firms began to register with the council (there was a growth of 60 per cent in the number of registered employers and 40 per cent in registered employees). But the parties on the council did not adopt effective strategies to recruit these firms or their employees. So, as the number of registered firms increased the representivity of the parties declined. By the time the CBIBC's agreement lapsed in November 2005 and it applied for the extension of its new agreement, the representivity of the party trade unions had dropped from just above 50 per cent to below 30 per cent. The representivity of the party employers' organisations slipped from above 55 per cent to just under 50 per cent (based on the number of employees they employ). The council was informed by the Department that it could not recommend to the Minister that he extend the agreement to non-parties.

The council responded with a strong motivation as to why the agreement should be extended despite the lack of representivity of the parties. The motivation focussed on a number of factors that the Department had indicated were important when considering extension of agreements. It argued, firstly, that the council had removed all unnecessary or onerous terms from its agreement that could prevent the establishment of new businesses or could burden existing businesses. Second, it stated that it has a policy of inviting input from all registered organisations regarding wages and conditions. It noted that the Small Builders Association had been given observer status on the council and that it interacted with the South African SubContractors' Association (SASCA), which had become virtually dormant but was being revived. The latter organisation had made some suggestions regarding changes to the council's constitution, which the council was examining. Furthermore, in an effort to assist the SASCA to increase its membership so as to obtain representation on the council, the council had created a facility to collect membership contributions on its behalf.

Third, the council had regional wage differentiation: three areas are delineated in the agreement (Peninsula, Boland and Malmesbury) for which there are separate wage schedules. It had also contemplated a blanket exemption for small building firms but its investigation revealed that 60 per cent of registered firms had less than ten employees. It did not believe it

22 The council has software which allows it to make up the payroll for a firm each week. The employment bureau comprises a database of employees that have ceased to be contributors to its funds (that is,. in most cases because they have become unemployed). Employers can lodge a request for workers via the council's website or telephonically and the council will supply names from the database.

23 Much of the section that follows is based on documentation supplied by the previous Secretary of the CBIBC. 
was feasible to exempt such a large proportion of the industry from its agreement. This was one of the reasons it had adopted its much more 'user-friendly' approach, which it believed had proved a successful alternative. It had also created a special 'labourer' category in its agreement for new employee entrants into the industry. Such labourers receive a slightly lower wage (believed to be lower than the market rate) and do not make contributions to the pension or provident fund for (approximately) two years. Finally, the council argued that it received very few exemption applications and the majority of those were granted. This, it argued, was an indication that small building firms were adequately accommodated in the agreement.

The council has also made a strong argument to the Department that the low representivity of the parties should be viewed within the context of the labour market in the industry. It pointed to the substantial 'churn' in the industry: 10000 to 11000 new employees (mostly unskilled) come into the industry each year and leave within a short space of time. This made it extremely difficult for parties, particularly the trade unions, to keep a high level of representivity. To illustrate this point by way of a comparison, the council states that the unions represent 78 per cent of the artisans covered by the council.

The Department did not relent and refused to extend the agreement, even for a short interim period to allow the parties to try to up their representivity. The party trade unions subsequently proposed a massive recruitment campaign, endorsed by the employer parties, which aimed at signing up 600 new members a month. This was presented to the Department with the request that the Minister extend the agreement to 30 June 2006 while the unions pursued the strategy. Again, this was not successful, and it appears that the unions have in any event not met the recruitment targets.

The bargaining council has now launched its own strategy to try to deal with the representivity problem. On the registration form for employees coming into the industry for the first time, it has included provision for them to join one of the party trade unions. They are not compelled to do so, but an inducement is offered: if they sign up with one of the unions then and there they get their first year's membership free. The council send the name and details of the employee to the relevant union if they sign up. Clearly, the idea is to make inroads into the large number of new entrants to the industry each year. To date it has been moderately successful but not to the extent that unions are representative.

Late in 2006 the council had further discussions with the Department but its officials still indicated a reluctance to recommend to the Minister that he extend the agreement. However, the council had not let the matter drop. It had arranged a presentation to senior Department officials in 2007 at which they would again argue their case.

What is remarkable is that the council has remained relatively stable despite not having an extended agreement for over a year. There has been no loss of membership of the party 
employers' organisation, small firms continue to register voluntarily with the council, and the council continues to be financially sound. The council believes that the reason is because of the strategies it adopted about three years ago (see above). This is probably the case. But the Department could argue that the stability of the council and the efforts it and the parties are being forced to make justifies its decision not to recommend extension. It is probably too early to tell which is correct. For the council's part, it believes that the Department is using representivity as a big stick to beat councils with rather than supporting councils, for example by subsidising some of their functions.

\section{The Southern and Eastern Cape Building Industry Bargaining Council}

The Southern and Eastern Cape Building Industry Bargaining Council is also old and wellestablished. It comprises, on the employer side, the East Cape Master Builders and Allied Industries Association and the Electrical Contractors and Allied Industries Association, and, on the union side, the National Union of Mineworkers and the Amalgamated Union of Building Workers. The council covers a large area around Port Elizabeth and through the southern Cape. About 600 employers were registered with the council and about 6000 employees.

The Southern and Eastern Cape Building Industry Bargaining Council was in a similar situation to the CBIBC. It estimates that about 6000 of the 12000 employees working in the industry were not registered with the bargaining council, mainly because they were employed in labouronly sub-contracting arrangements. Of the 6000 registered employees, it estimates that about 60 per cent were employed on fixed-term contracts (mainly the unskilled workers) (Bezuidenhout et al, 2004: 48). Furthermore, there is a high labour turnover. Many workers are retrenched at the end of building projects, making it difficult for unions to maintain representivity.

In September 2001 the council's main agreement expired and was not renewed. The employer party, the Eastern Cape Master Builders and Allied Industries Association (MBA), refused to negotiate a new agreement because it alleged that the unions were not sufficiently representative (the unions represent about 35 per cent of registered employees whereas the employers' organisation represents close to 60 per cent of building firms). The MBA subsequently applied to the Labour Court to have the bargaining council wound up, alleging inter alia that:

- $\quad$ The number of active employees in the industry had declined dramatically;

- Employers were compelled to subsidise enforcement of the collective agreement against defaulting employers;

- The council was incapable to effectively monitoring compliance with its main agreement; 
- The assets of the council had shrunk dramatically; and,

- Building industry bargaining councils in other provinces had closed down. ${ }^{24}$

The application was dismissed. It was held that the poor representivity of the union parties to the council and the decline in the number of employees in the industry did not constitute sufficient reasons to wind up the council. The financial difficulties were also not a sufficient reason as this would probably not be a permanent situation (the council had taken steps to rationalise staff). However, what seemed to carry the most weight for the Court was the fact that the employers' organisation was not seeking to terminate the bargaining relationship with the unions. What it wanted was to discontinue bargaining in the council and to thereafter bargain in a non-statutory and informal bargaining forum that it wished to establish. The Court concluded that the proposed bargaining mechanism would not "appear to augur well for the interests of all the parties, particularly the employees". ${ }^{25}$ Such an arrangement would, therefore, not be within the spirit and objectives of the LRA.

The bargaining council continues to exist but no longer functions as a collective bargaining forum because the employers' organisation still refuses to bargain at the council. There has not been a collective agreement since September 2001. The council now administers various social security funds (that is, the pension fund, the provident fund, the medical aid fund, the sick benefit fund, and the holiday fund), does dispute resolution functions (it is accredited by the CCMA for conciliation and arbitration), and performs certain secretariat functions (there are still monthly executive council meetings and four full council meetings each year).

Collective bargaining continues within the industry at pockets of employers. Two so-called voluntary bargaining groups (VBGs) have been established in the Port Elizabeth area and in the Southern Cape. These negotiations have resulted in agreements that introduce wage increases (they set only a percentage increase rather than a minimum rate). The agreements are not gazetted and are not extended to non-parties. However, it appears that the increases do tend to be followed by at least some firms outside the VBGs. There does not appear to be any collective bargaining taking place at individual firms outside the VBGs.

The VBGs, as the name indicates, are voluntary. They comprise groupings of employers that have agreed to bargain centrally with the unions in a VBG. But it seems that the VBGs are part of a larger scheme that the MBA is proposing to the union as an alternative to the bargaining council. In terms of this scheme (or at least one version of it) it is proposed that unions can bring other firms into the VBG by achieving 50 per cent representivity at the firm. In other words, if a VBG is set up by a group of firms in an area and the unions get 50 per cent

$24 \quad$ East Cape Master Builders \& Allied Industries Association \& another $v$ Building Industrial Bargaining Council (Southern \& Eastern Cape) \& others; [2004] 4 BLLR 356 (LC). 
representivity at other firms in the area then those firms will be incorporated into the VBG. A lower threshold of 40 per cent representivity is also being considered. The key to the VBG model is, therefore, that bargaining only takes place where unions are representative. This addresses the major gripe employers had with the council; they were bargaining for too many workplaces where unions had few or no members.

There is disagreement amongst the parties about the status of the VBGs. The VBGs comprise groups of MBA members and are represented in negotiations by the Director of the MBA, but the employers' organisation stresses that it is not party to the agreement; the party is the group of employers. To an extent, the bargaining council has been involved in facilitating these negotiations but on the understanding that these are taking place outside the bargaining council and are not 'official' bargaining council negotiations. However, the National Union of Mineworkers (NUM) is adamant that these are agreements with the MBA and are not 'outside' the bargaining council.

Currently no negotiations are taking place about the future of the bargaining council itself. But the employers' organisation has put forward a number of proposals about alternative bargaining structures. These, the MBA state, have been based on a lot of research and investigation of bargaining arrangements in the KwaZulu-Natal building industry and in Australia. There is currently a further proposal on the table from the employers' organisation about the way in which bargaining should be structured. This was being studied by the trade unions. But it appears that the parties are very far apart and there is a lot of bad blood between them. Unions want the bargaining council back with its collective agreement, whereas employers want something completely new, a structure that is much more streamlined and flexible. Neither side seems to want to budge from its position. Whether a compromise can be reached remains to be seen.

In the meantime the employers are in the stronger position. Unless the unions can considerably increase their representivity there is not much they can do about restoring the bargaining council as a collective bargaining forum and getting its agreement extended. On the other hand, the MBA argues that it has put a lot of effort into finding a solution to the issue of the appropriate bargaining structure. It believes the easiest option would probably be for it to simply go back into the council. But this would not be in the interests of the industry. This is why it has invested so much time in the search for a viable alternative. It wants to establish a bargaining arrangement that is appropriate for and benefits the industry. It is, therefore, very frustrated by the unions' insistence that there is no alternative to the bargaining council.

NUM remain very strongly committed to the bargaining council. In fact, it wants much more than restoration of the council as a collective bargaining forum. It wants to have the agreement extended, to incorporate the East London region and eventually have an agreement covering the entire Eastern Cape Province, and then it wants a national bargaining council. The union 
acknowledges, however, that this expansion of the scope of the council will have to be on the basis of it becoming representative in these areas.

It is important to note the influence of the tougher stance by the Department of Labour regarding representivity. This was made clear to the council during a visit by Department officials some time after the lapse of its agreement. The MBA are using this tougher approach to support its position, that is, there is no point in negotiating and submitting agreements to the Department if the agreement is not going to be gazetted or extended because the representivity of unions is so low. And, in the council's opinion, it is definitely a new and tougher stance being adopted by the Department. In the past it had agreements extended without any problems where the union parties were only 35 per cent to 40 per cent representative, a fact that was confirmed by the MBA.

Somewhat surprisingly, the council is financially quite stable. In the last five years the council has gone from having a big deficit to having a small surplus. The financial turnaround is all the more significant because it has happened at the same time that the council has lost 40 per cent of its contributing employers (that is, the non-extension of its agreement means that non-party employers are no longer obliged to pay a levy to the council). But financial stability has come at a cost: the council has reduced its staff by 25 per cent, has cut services, and has rationalised in other areas. It also remains in a precarious position because it does not have an agreement.

The two case studies highlight the diversity in the bargaining council system and the difficulty of making generalisations. What is common to both is the impact of the Department's tougher stance with regard to the interpretation of 'sufficient representivity' for the extension of agreement. A further common factor is that both have survived the non-extension of their agreements and seems to be on fairly firm ground financially. But there the similarities end.

\section{Research on Other Bargaining Councils}

In addition to the above councils, interviews were conducted with officials of the bargaining councils in the metal and engineering industry, the road freight industry, the motor sector, and the leather industry. These interviews (as well as the interviews with the two building councils) sought to gain in-depth information on the operation of the councils, the challenges they were facing, and how they were meeting these challenges. The findings are discussed below under a number of headings.

\section{Coverage of the Councils and Agreements}

Four of the councils were national in coverage, although not all covered what were previously the TBVC states (formerly Transkei, Bopuphatswana, Venda, and Ciskei), while the two 
building industry councils were regional. ${ }^{26}$ All the councils regulate wages and conditions of employment as well as providing a wide range of social benefits. In most cases the latter are provided in separate agreements but in the case of the Cape Building Industry Bargaining Council everything is dealt with in one agreement. The period of the main agreements (that is,. the agreements that deal with wages and conditions of employment) varies. Three councils have one-year agreements, although in one case the wage schedule has been extended for three years. One council has a two-year agreement and another has a three-year agreement. Social benefits dealt with in separate agreements are generally effective for longer periods.

As noted above, the Southern and Eastern Cape Building Industry Bargaining Council does not currently have a main agreement and the Cape Building Industry Council has not had its main agreement extended. In addition, the Road Freight Bargaining Council had difficulties getting its main agreement extended because of low representivity. Eventually only the section dealing with wage rates in the agreement was extended. The remaining councils all had their main agreements extended.

\section{Variation}

Most of the councils had introduced different forms of downward variation of wages and/or conditions of employment. In one case variation was regional and in another the variation was for a sub-sector. In the case of the Motor Industry Bargaining Council the variation is occupational and regional, that is, there is variation of certain conditions for petrol pump attendants and there is also urban/rural variation for petrol stations. The Cape Building Industry Bargaining Council also provides variation for entry-level labourers for a period of about two years, after which the employer must comply with the agreement in full.

The Leather Bargaining Council had introduced the most far-reaching variation. This bargaining council comprises three chambers: Tanning, General Goods, and Footwear, of which the footwear sector is the most important. With trade liberalisation and the huge influx of cheap shoes the local footwear industry was on the verge of collapse. As a consequence there was huge pressure on the bargaining council. The retrenchment of footwear workers saw an upsurge in informal shoe-making operations and homeworking, undermining the labour standards set by the council. Employers and unions then made a radical change to the footwear collective agreement. Footwear firms now fall into one of three categories: formal, semi-formal and informal. Eight criteria are used to classify the firms into these categories, with points being awarded in respect of each criterion. ${ }^{27}$ Firms categorised as formal pay 100 per cent of the set wage rate and comply with the rest of the agreement (although negotiations

$26 \quad$ Although moves are afoot to include these areas within the jurisdiction of the councils.

27 The criteria are: product type; number of employees; balance between component manufacturing and completed footwear; whether it is a branded product; type of operation; geographical areas; primary raw material; and, primary customer. 
at the company level can reduce the wage rate to 80 per cent). Semi-formal firms comply with the agreement but are required to pay only 75 per cent of the set wage rates (although negotiations at the company level can reduce the wage rate to 60 per cent). 'Informal' firms are excluded from the agreement entirely (but must still register with the council).

One can criticise the agreement because workers at 'informal' firms are not covered and get protection only from the Basic Conditions of Employment Act. However, it could be argued that even if they were covered it is unlikely the bargaining council would have the capacity to enforce its standards at these firms. Informal operations are notoriously difficult to locate and bring to book. Furthermore, according to the council, the new arrangement has given more stability to centralised bargaining in the footwear sector.

\section{Minimum and 'Actual' Wages, Plant-Level Bargaining, and Productivity Agreements}

As the discussion in the historical section above indicated, the unions that emerged after 1973 sought to bargain at industrial council and plant-levels. Employers were strongly opposed to bargaining at more than one level. This contest seems to have been won by employers, but in some cases it has required them to agree to negotiating 'actual' wage increases as a tradeoff. ${ }^{28}$ This has been to the detriment of plant-level bargaining and the negotiation of productivity agreements.

Most of the councils researched had introduced a prohibition on plant-level bargaining over the issues covered in the bargaining council agreement. However, the Leather Bargaining Council provided a variation in that such a prohibition operated only in the Tanning main agreement. As noted above, the Footwear main agreement makes specific provision for plantlevel bargaining, although only to vary the conditions in the agreement downwards. In only one case had such a prohibition resulted in a trade-off to negotiate 'actual' wage increases (this is the Metal and Engineering Bargaining Council). The Cape Building Industry Bargaining Council provided a variation on this arrangement. It negotiates on the minimums but a person earning above the minimum will get the Rand difference between the old minimum and the new minimum. In addition, the components sector within the Motor Industry Bargaining Council negotiates 'actual' wage increases (but the rest of the industry negotiates increases on the minimum rates).

None of the interviewees at the bargaining councils had much knowledge of the extent of plant-bargaining outside the council, but all had a strong sense that there was little or no plant bargaining taking place. More research would need to be done to confirm this finding. But it

28 Actual' wages generally refers to the application of a wage increase to the actual wage an employee earns rather than just to the minimum rate in the agreement's wage schedule. In other words, a person earning above the minimum must get the full increase. 
suggests that unions have become increasingly focussed only on bargaining at councils, which could mean a deterioration of organising and servicing of members at the workplace.

The impression that there is very little bargaining taking place at the plant-level also suggests that productivity bargaining is not taking place. This tends to be confirmed by the experience of at least two councils. Both the Metal and Engineering Bargaining Council and the Motor Industry Bargaining Council made mention of discussions regarding productivity some years ago. In the case of the former council, the discussions resulted in a 1997 framework agreement on productivity that was incorporated into the main agreement. The agreement sets out the principles, guidelines and objectives that firms should follow to negotiate productivity agreements at plant level. The key principles are: productivity gains must be shared among the workers concerned; all work re-organisation must be negotiated; health and safety standards must not be compromised; and, productivity agreements at plant-level must be voluntary (Webster, 1999: 30). However, it appears that there has been little or no take-up at plant-level. In the case of the latter council, the discussions did not lead to an agreement and the issue seems to have been dropped.

\section{Enforcement}

Enforcement of the agreements of bargaining councils is the task of designated agents. There is wide variation in the number of agents employed by councils. For example, the Motor Industry Bargaining Council employs sixty agents whereas the Leather Bargaining council, which is also a national council, employs only five agents. The Cape Building Industry Bargaining Council employed sixteen agents until its agreement was not extended, after which it had to retrench six agents.

The enforcement policy of a council can allow for a certain degree of variation, although there are obvious dangers associated with giving agents too much latitude when dealing with struggling employers. Councils generally err on the side of caution. In most cases agents must follow a strict procedure in dealing with employers. If latitude is going to be given to the employer then it is for the council to do this rather than the agent. The Cape Building Industry Bargaining Council had the most developed system of variation for agents. Its agents can issue a non-compliant employer with a Certificate of Intent, which gives the employer three months' leeway to comply with the agreement. However, the council also indicated that it had a policy of rotating agents so that they did not become too familiar with employers. On the other hand, the Metal and Engineering Bargaining Council indicated that agents did not have latitude but the council was encouraging agents to approach their work more as facilitators than policemen. The council did, however, exercise a certain discretion with regard to writing off amounts owed to the council, that is, levies (but not amounts owed to employees or benefit funds). 
Lack of enforcement allows for considerable variation, although of the wrong kind. In such cases the option of not registering with a council and not complying with its agreements becomes less risky and more attractive. This process is fuelled by the trend to outsource functions to smaller sub-contractors (for example, in the building industry), to homeworkers (for example, in the clothing industry), and to independent contractors, most of which do not register with the relevant council. The growing number of informal employers ultimately poses a threat to the viability of the council. However, none of the councils included in this research saw non-registration as a major threat and believed that enforcement was relatively effective. The Leather Bargaining Council, which could be seen as the most vulnerable given the low number of agents it employed, had largely solved the problem of informalisation by specifically excluding informal firms (see above).

\section{Dispute Resolution}

A large number of bargaining councils are now accredited with the CCMA to perform dispute resolution functions, either conciliation only or conciliation and arbitration. All the councils covered in the research project, including the two building sector councils, were accredited for dispute resolution. In some cases the function was performed by council staff, or council staff in conjunction with a panel of outside commissioners, but in other cases, notably the Metal and Engineering Bargaining Council, the dispute resolution function had been contracted to an outside agency.

All the councils indicated that dispute resolution was an important function for the council to perform. However, the subsidy provided by the CCMA does not cover the cost of providing the service, which meant that performing the dispute resolution function was a drain on the councils' finances. One council estimated that the CCMA subsidy covered about 10 15 per cent of the cost of dispute resolution (excluding enforcement cases), while others provided estimates of 40 per cent and 45 per cent. One of the councils had decided to become accredited only for conciliation in part because of cost considerations.

Perhaps the most glaring anomaly is highlighted by the two building councils, one of which does not have an agreement, while the other does not have its agreement extended. In both cases the councils continue to provide the dispute resolution service for all firms and workers in their jurisdiction. So, while neither council may enforce its agreement on non-parties they continue to provide the dispute resolution service for non-parties. This is an unacceptable burden for party employers and employees. They are paying a levy that funds a vital but poorly subsidised service, without having the benefit of a council agreement that obliges competitors and fellow workers to also pay the levy. 


\section{Training}

Prior to the new LRA and SDA a number of industrial councils had training schemes or had industrial training boards functioning in their sectors. Training was seen as an important function or potential function of industrial councils, particularly by COSATU. The implication was that training was an issue for negotiation between employers' organisations and unions. The LRA acknowledged this function in respect of bargaining councils, but the introduction of the SDA saw training being separated from councils.

Although the Skills Development Act makes provision for officials of bargaining councils to be invited onto the boards of SETAs, none of the councils researched had received such an invitation from their respective SETAs. In one case, however, the Chief Executive Officer (CEO) of a council had regular informal meetings with the CEO of the SETA and believed that this was adequate. But other councils indicated that they felt that representation on the SETA would be useful. On the other hand, the parties of the councils had overlapping representation, that is, employers' organisations and trade unions that were parties to councils were also represented on the SETAs.

In general, the interviewees at councils were quite critical of the performance of SETAs. Most believed that the prior training dispensation, whether via an industry training board or the council's own scheme or a combination of the two, had been more effective. At the very least there was a perception that the much wider scope of SETAs meant that the sectors covered by bargaining councils were not receiving the attention that they needed with regard to training (and had received in the past). So there was a view that in the past the training dispensation had been more focussed and effective for the relevant (more narrowly defined) sector. It might be argued on this basis that there needs to be more, smaller SETAs, which is contrary to the current trend of amalgamating these institutions.

A second issue is thrown up by the example of the National Bargaining Forum (NBF) for the Automobile Manufacturing Industry. In the case of the NBF a training dispensation had been negotiated that is closely linked into the grading system and wage structure, as well as the productivity goals of the industry. The divorce of training from councils via the SDA appears to have placed a barrier between collective bargaining and training that makes it impossible to achieve the sort of nexus that has been obtained in the NBF. Of course, one can argue that unions are represented on SETAs and there is nothing to stop collective bargaining taking place in that forum over training issues. But it seems that the capacity problems faced by most unions have undermined effective representation on SETAs, so that in many cases training is not properly negotiated. This is an issue that needs more research. 


\section{NEDLAC and Industrial Policy}

The LRA makes provision for bargaining councils to make submissions to NEDLAC over matters affecting their sectors. The potential of councils to provide an industry-wide forum for industrial policy as well as industrial relations issues was an argument made by unions in support of more centralised bargaining. However, not one of the bargaining councils included in the research had ever made such a submission to NEDLAC. Only in the case of the Metal and Engineering Bargaining Council is there formal contact with NEDLAC because the CEO of the council sits on the Metals Sector Sub-Committee within NEDLAC. It might be the case that the various sector summits have made this provision redundant, but it is surprising that unions and employers have not explored this potential of councils.

\section{Finances}

There are some positive signs when one views the bargaining council system, but the decline in the number of councils, and the threats councils face, give an overall impression of a system under a great deal of pressure. Surprisingly, however, the financial circumstances of the councils researched are quite healthy. This is even the case with regard to the two building sector councils. In most cases this was not fortuitous, but was the result of positive steps taken by councils.

We did not collect financial data from councils. The findings in this regard are qualitative and rely purely on what was reported during interviews. However, a fairly strong pattern emerges across the councils of financial difficulties being faced about four to five years ago. This resulted in the councils restructuring and re-strategising, often under the leadership of a new secretary, to the extent that the financial situation has turned around and is now stable. As noted above, this has been the case even where councils do not have an agreement or do not have an extended agreement, as with the two building sector councils.

The improvement in the financial position of councils has not been without a cost. In three cases the restructuring entailed a reduction in staff. Although councils stressed that an aim of the restructuring was to improve efficiency, it is arguable that the reduction in staff has led to some reduction in services and/or enforcement capacity. However, this is an issue for further research.

The diversity amongst bargaining councils makes it impossible to come up with a definitive conclusion regarding the state of the system or even a general assessment of its health. In the above section we have therefore tried to give a sense of the situation of some bargaining councils, including the major threats to councils as well as some of the innovations that have emerged. But the question remains how important is the system? Do bargaining councils continue to be the main vehicles for setting wages and terms of conditions through collective bargaining? 
These questions can be answered in part by breaking down the entire economy into sectors (as defined by Statistics South Africa) and mapping bargaining councils onto the sectors. This gives one an idea of the coverage of the system.

Table 2: Bargaining Councils and Employee Coverage by Sector

\begin{tabular}{|l|c|c|c|}
\hline Sector & $\begin{array}{l}\text { Total employees } \\
\text { (grades 4 - 9) }\end{array}$ & $\begin{array}{l}\text { Number of } \\
\text { councils }\end{array}$ & $\begin{array}{l}\text { Employees covered by councils } \\
\text { (grades 4 - 9) }\end{array}$ \\
\hline Agriculture \& fishing & 688620 & 2 & 10522 \\
\hline Mining and quarrying & 376501 & 0 & 0 \\
\hline Manufacturing & 1230177 & 18 & 569441 \\
\hline Utilities & 59207 & 0 & 0 \\
\hline Construction & 594780 & 6 & 47052 \\
\hline Trade & 1333239 & 5 & 192026 \\
\hline Transport \& storage & 397669 & 4 & 286116 \\
\hline Finance \& business & 671601 & 1 & 10543 \\
\hline Community services & 1890157 & 13 & 1285568 \\
\hline Total & 7241951 & $49^{30}$ & 2401268 \\
\hline
\end{tabular}

Source: Godfrey et al, 2006: 22-23

Table 2 shows that while the bargaining council system is important, it covers only about a third (33 per cent) of all workers that would normally fall within a collective bargaining unit. Four of the nine major sectors of the economy do not have a bargaining council, or the councils that do exist are small and cover only a very small proportion of the workers in the sector, that is, agriculture and fishing; mining and quarrying; utilities; and, finance and business. A number of bargaining councils are present in another two sectors but their coverage is very low (less than 15 per cent in both cases), that is, construction and trade. So, bargaining councils cover a significant proportion of employees in only three sectors, that is, manufacturing; transport and storage; and, community services. The strength of the system in the latter two sectors is mainly because of the Transnet Bargaining Council and the five public sector councils respectively, whereas the manufacturing sector comprises a quite large number of councils across a number of industries.

However, to assess how important the bargaining council system is relative to other bargaining forums, one needs to know the extent and coverage of the collective bargaining system outside of councils. We try to do this in the sections that follow.

\subsubsection{Statutory Councils}

In terms of the LRA a statutory council can be established on application by either a 'representative' trade union or employers' organisation. A 'representative' trade union is a registered union (or two or more acting jointly) that has as its members at least 30 per cent

29 Grades 4-9 cover those occupations that would normally be included in the bargaining unit, that is, clerks service workers and shop and market sales workers; skilled agriculture and fishery workers; craft and related trades workers; plant and machine operators; and, elementary occupations. 
of the employees in the sector and area for which it wants the statutory council established. Similarly, the member firms of a 'representative' employers' organisation must employ at least 30 per cent of the workers in the relevant sector or area. If an applicant union or employers' organisation is representative and complies with certain formalities, the Registrar of the Department of Labour must establish the statutory council. A process then follows to get other parties to participate on the council, either through agreement or appointment by the Minister, which then leads to registration of the council.

Since 1996 a number of statutory councils have been established but were never registered, including the Statutory Council for Blood Transfusion Services, the Statutory Council for the Home Textile Industry, and the Statutory Council for the Security Industry (Western Cape). In addition, there currently exists a Statutory Council for Squid and Related Fisheries that has yet to be registered.

There are various reasons for the failure of these statutory councils to see through the process to registration. On the one hand, the Statutory Council for the Home Textile Industry was abandoned because it was overtaken by the establishment of the National Textile Industry Bargaining Council. The home textiles sector was incorporated into the new national bargaining council, formed by the amalgamation of a number of existing sub-sectoral textile councils, thereby making a statutory council unnecessary. On the other hand, the establishment of the Statutory Council for Security Industry (Western Cape) appears to have been initiated by a union in the Western Cape. Security industry employers in the Western Cape, however, boycotted the process and it seems no progress was ever made to registering the council.

This latter case points to the problems in the statutory council model. While the LRA provides for various steps that can be taken to appoint employer representatives once a council has been established, if employers are opposed to such a council it seems that no amount of compulsion is going to get them to participate and get the council registered. This problem applies equally to unions and employers, as the case of the Statutory Council for the Squid and Related Fisheries illustrates. Here it is an employers' organisation that made the application for the statutory council (the Employers Organisation for the Cephalopod and Associated Fisheries). This was done in early 2005. The Department of Labour then did the necessary work to publicise the establishment of the council in order to get unions to participate. But no unions responded. ${ }^{31}$

Although the LRA makes provision for the process to go ahead without union involvement, that is, the Minister appoints employee representatives, it seems that the Department of Labour were reluctant to go this route until they had thoroughly canvassed possible union parties. A period ensued during which the Registrar made a number of efforts to discuss the council

31 Much of this section draws on telephonic interviews with the Registrar and another official of the Department of Labour on 06.03.2007. 
with unions and encourage their participation. These were unsuccessful. So the process has ground to a halt, with considerable frustration on the side of the employers' organisation. Again, the process set out in the LRA that embodies the compulsory aspects of the statutory council model, is clearly difficult to implement in practice when one side is not organised or interested.

The statutory council model, therefore, does not provide a particularly easy route to establishing a centralised bargaining forum. But it is possible to overcome the problems in the model, because to date two statutory councils have been set up and registered. These are the Statutory Council for the Printing, Newspaper and Packaging Industry of South Africa and the Amanzi Statutory Council. Both were established through the initiative of trade unions and both are relatively stable. But neither has accomplished a great deal so far in terms of collective bargaining.

\section{The Statutory Council for the Printing, Newspaper and Packaging Industry}

The Statutory Council for the Printing, Newspaper and Packaging Industry of South Africa was the first statutory council to be registered. ${ }^{32}$ Its path to registration was not an easy one although it did have one apparent advantage, namely a long history of centralised bargaining in the sector. The Industrial Council for the Printing, Newspaper and Packaging Industry was the very first industrial council to be registered under the Industrial Conciliation Act, 11 of 1924. It was also the first major casualty of the struggle over centralised bargaining during the 1980s. When the Paper, Printing, Wood and Allied Workers Union (PPWAWU) applied to join the council in 1989, on the basis that the union was going to continue to bargain at company and plant-level, the Printing Industries Federation of South Africa withdrew, thereby collapsing the council. The question that the application for a statutory council posed was whether the reasons for the demise of the council would be outweighed by the history of centralised bargaining in the sector.

The application for the establishment of the statutory council was made by the South African Typographical Union (SATU). This was the union that for many years had been a party to the old industrial council. In fact, it had taken over the council benefit funds when the latter collapsed. SATU's intention in applying for the establishment of a statutory council was to ultimately set up a bargaining council in the sector. The union understood this to be the purpose of the statutory council model in the new LRA and at the time they easily met the membership threshold (they represented about 60 per cent of the employees in the industry). However, it was a long and drawn-out process to get the statutory council registered.

32 This section draws on interviews with Martin Deysel, General Secretary of the South African Typographical Union, on 06.12.2007, and with Chris Sykes, Chief Executive Officer of the Printing Industries Federation of South Africa, on 23.01.2007. 
The delay initially arose with regard to the demarcation of the scope and area of the proposed council. SATU had applied for a statutory council with exactly the same broad scope and area as the previous industrial council. This hit snags in the NEDLAC Demarcation Committee, although there are differing recollections of the cause of the problems. According to SATU, it was opposition from COSATU, acting on behalf of Chemical, Energy, Paper, Printing, Wood and Allied Workers' Union (CEPPWAWU), because the latter union wanted to establish a bargaining council rather than a statutory council in the sector. But the Printing Industries Federation of South Africa (PIFSA) is of the view that the plastics sector was the main sticking point. The sector was a stronghold for CEPPWAWU and the union did not want it included in the scope of the proposed statutory council. ${ }^{33}$

The opposition meant that SATU had to go back to argue its case to the NEDLAC Demarcation Committee a number of times. In the end, the application for the council was referred to the Minister without a recommendation by the Demarcation Committee. The Minister approved the scope and area of the council as per the SATU application and established the council. However, there were more delays because of further opposition from CEPPWAWU, which culminated in an application to the Labour Court challenging the Minister's approval of the council. Ultimately the union withdrew the application a few days before the matter was to be heard and the council was finally registered in June 2001 (Du Toit et al, 2006: 45). Both SATU and CEPPWAWU are parties on the council.

Were there aspects of the legislative framework for statutory councils that were to blame for the delays? In other words, are there changes that could be made to the LRA that would make the process easier? By all accounts the drawn-out process was not the fault of the legislative framework. None of the parties identify any particular provision that caused problems. Part of the explanation for the delay is the fact that this was the first statutory council to be established and all the parties, including the Department of Labour, were feeling their way. For the rest, it was the conflicting interests of the various parties that held up the process.

Most employers do not appear to have been strongly opposed to the establishment of the council. An initial problem was that there was no registered employers' organisation in the sector; PIFSA had de-registered as an employers' organisation after it withdrew from the previous industrial council. However, this was resolved by employers establishing four employers' organisations to represent them on the council. These are the Printing Employers' Association, the Independent Packaging Association, the Print Media SA Association, and the Paper Packaging Association.

33 It seems that CEPPWAWU's plan was to link plastics with the forestry and related sectors; it is unclear whether the union wanted to establish a bargaining council for this sector. 
An additional factor behind employers' relatively positive response was that some major employers had changed their stance on centralised bargaining. Nampak had been prominent in the move to collapse the old industrial council. However, the company was then targeted by PPWAWU and was hit by a strike, in the course of which it indicated its willingness to enter discussions over the issue of centralised bargaining. The pressure being exerted by the union and the subsequent discussions led to a change of heart on the part of Nampak, with Kohler and Mondipak following suite. However, Nampak apparently contends that it did not change its views on centralised bargaining because of union pressure but rather on business grounds, that is, the company was being undercut by small firms in the industry and wanted to use centralised bargaining to set a floor for competition. But, whatever the reason, Nampak, Kohler and Mondipak became a grouping in the industry that was in favour of centralised bargaining.

Although employers formed four employers' organisations (which represent 75 per cent to 80 per cent of employers in the industry) to participate in the statutory council, it appears that their support for centralised bargaining is conditional, that is, there is strong opposition (outside of the above three firms) to centralised bargaining over wages and other conditions of service, which are currently bargained at corporate group, company and plant levels. A statutory council, with its limited bargaining agenda and potential to conduct dispute resolution for the sector, was therefore seen as acceptable and possibly even beneficial. But there is strong opposition to it being used as a platform for establishing a bargaining council.

Given the above it is probably not surprising that no substantive collective agreements have been produced by the council. There has been an agreement regarding levies to fund the council and infrastructure has been put in place to collect levies from employers. A seemingly anomalous snag was hit trying to get the levy agreement extended to all employers. According to interviewees the Department declined to extend the agreement because it holds that the route that statutory councils must go to have their agreements extended is section 44 of the LRA. ${ }^{34}$ This misinterpretation is clearly an impediment for statutory councils and urgently needs to be clarified.

Other than the levy agreement and infrastructure to collect levies, the statutory council is accredited by the CCMA to perform conciliations and arbitrations. By the end of 2006 they had processed about 400 disputes. The vast majority were settled within 30 days of referral. This aspect of the council therefore appears to have been beneficial for the sector. However, it comes at a cost (the dispute resolution function is the main expense of the council). The

34 However, section 44 provides a procedure for councils that are not sufficiently representative. Because the council is representative, the Department states that the section does not apply and it cannot extend the agreement. This is incorrect. A statutory council can send an agreement to the Minister in terms of section 32 for extension (in the same way a bargaining council can), and if it is representative or sufficiently representative in terms of that section the Minister should extend it. This is provided for by section 43(3). Section 44 applies only if it is held that the council is not sufficiently representative. 
subsidy provided by the CCMA generally only covers a proportion of the actual cost of the dispute resolution function. The objective of the levy agreement is to provide funds for the council so that it can continue to perform this and other functions. The refusal to extend the levy agreement means that non-party employers and employees can access the council's dispute resolution system without contributing financially.

It was noted above that SATU had taken over the benefit funds of the previous industrial council. When the statutory council was established it was agreed that the benefit funds would not transfer to the council (the same applied to a provident fund administered by CEPPWAWU). However, it was also agreed that the parties could at a later point bring one or more of the funds under the ambit of the council. To date this does not seem to have been contemplated.

The LRA provides that one of the powers and functions of a statutory council is to "promote and establish training and education schemes". However, given the Skills Development Act and establishment of SETAs, the statutory council decided at the outset that it would not deal with training. Training has therefore been left to the SETA. The Printing Industries Federation of South Africa (PIFSA) states that most employers would prefer the statutory council to deal with training because it is much more focussed on the sector, whereas the scope of the SETA is much wider. The implication is that the SETA is not giving the sector the attention that it needs.

What are the prospects of the statutory council becoming a bargaining council? For SATU it is clear that the statutory council is a stepping stone to a bargaining council. The plan was to put structures and a levy-collecting system in place through a statutory council. With this infrastructure in place a bargaining council becomes much more feasible. The employer side is more complicated. The paper packaging sector (where Nampak, Kohler and Mondipak are located) is in favour of a bargaining council. In the other sectors, however, there is strong opposition to a bargaining council. This throws up a number of possibilities, which the parties are currently debating. One route would be to divide the sub-sectors into chambers within the council, one of which (that is, the paper packaging chamber) would conduct bargaining over wages and other conditions of employment. Another route would be to set up a bargaining council with a chamber for each sub-sector, but with only the paper packaging chamber (at least initially) conducting collective bargaining over wages and conditions of employment. A further alternative would be to convert the statutory council to a bargaining council but to exempt those sectors that are opposed to bargaining over wages.

SATU's argument is that, whichever way they go, the objective would be to eventually have collective agreements over wages and conditions in all the chambers, that is, to have a bargaining council. However, SATU believes that it is essential that there are separate agreements for each chamber in order to accommodate the differences between the sub- 
sectors. The failure of the old industrial council to deal with sectoral differences was one of the reasons for its demise.

There is likely to be opposition to a bargaining council from the big printing and media firms as well as other employers. However, there has not been outright refusal to discuss some of the above options. The issue will be what benefits a council can offer employers. If the unions cannot demonstrate benefits, possibly by making some concessions to employers, many firms will resist the council. If forced into something they do not want they could always withdraw from the council, leaving it unrepresentative and with little chance of having its agreements extended. Ultimately this will cause its collapse. It would be a case of history repeating itself.

\section{The Amanzi Statutory Council}

The Amanzi Statutory Council was established by the South African Municipal Workers Union (SAMWU), which applied for the council and had the necessary representivity. A meeting was called in terms of the LRA to take the process forward. On the employer side were all the Water Boards established in terms of the Water Services Act (there are thirteen of them). After the initial meeting the parties negotiated a constitution for the council, which they submitted to the Minister. At that point there was no employers' organisation so the Minister appointed employer representatives to the council. The council was registered early in 2003. Subsequently an employers' organisation was formed, the South African Association of Water Utilities (SAAWU), which now represents employers. Three unions participate on the council: SAMWU, NEHAWU and UASA.

The current scope of the council is the thirteen Water Boards registered in terms of the Water Services Act. These are spread across the country. There are no non-parties. ${ }^{35}$ The council covers about 6600 employees.

To date the council has produced three collective agreements. One is in respect of the levy to finance the council. There is also an agreement regarding dispute resolution. This provides that, subject to CCMA approval, the council's dispute resolution function is outsourced to the South African Local Government Bargaining Council (SALGBC). The third agreement is with regard to organisational rights. This agreement closely follows the LRA's provisions, but it also provides for participatory structures called Local Labour Forums. There has also been in principle agreement about developing industry policies on HIVIAIDS, on health and safety, and on employment equity. Given that there are no non-parties the council has not had to ask the Minister to extend its agreements. 
In addition, there has been considerable discussion at the council over job evaluation systems: most Water Boards use the Hay system but SAMWU want to convert them to the Task system that is used at many local authorities. No agreement has been reached yet on the job evaluation issue. There has also been a lot of discussion around training, particularly with regard to workplace skills plans and the monitoring of employers' compliance in this respect. The main issue was that the unions were not being involved in the development of workplace skills plans at some Water Boards. It was decided that the statutory council would not get involved at the workplace level but would monitor whether plans were in place and that the union had signed off on them. However, the system appeared not to be working very well and the union had tabled a comprehensive proposal in this regard.

Wages and conditions of employment are negotiated at Water Board level. The first prize for the union would be to negotiate these centrally at the statutory council, but there is strong opposition from employers, mainly because there are very big differences between the wages and conditions at the various Water Boards. It should be noted that there are huge size differences between the Water Boards: at the one end there is Rand Water Board with over 3 000 employees and at the other end the Albany Coast Water Board with only six employees. Because the Water Boards are not competing with each other they see little reason to go through a complicated exercise to try to harmonise the differing wage levels and conditions.

Another reason for resistance to centralised bargaining over wages and conditions of employment is that some of the bigger Water Boards argue that they have established very good relations with workers and unions at the Board level. They are concerned that by removing negotiations to a central level they will lose their ability to maintain good Boardlevel relations. On the other hand, the smaller Water Boards are worried that centralised negotiations will result in agreements being imposed on them. But SAMWU argue that the council has an exemption procedure that is designed to deal with the consequences of these differences. However, the differences are a problem for the unions as well; specifically how the gaps between the higher and lower paying Water Boards are to be closed.

SAMWU's aim is to have all matters of mutual interest bargained centrally. This was its motivation for initiating the statutory council. It realised that a bargaining council was not a realistic prospect at that point and decided to try the statutory council option. Although the union has not made much progress to getting what it wants, either at the statutory council or in terms of transforming it into a bargaining council, it remains committed to the process. ${ }^{36}$ It provides a forum for discussing issues affecting the industry, it allows the union to bargain with employers over how particular issues can be dealt with at the Water Board level, and has given the union an opportunity to consolidate its organisation at the Water Boards. The union has also worked to put the foundations in place for bargaining over wages, that is, the 
organisational rights agreement and the negotiations for a uniform job evaluation system are stepping stones for wage bargaining at the council.

SAMWU argues that it has two routes it could go with regard to the statutory council. It could campaign for it to become a bargaining council or it could push for the SALGBC to extend its scope to incorporate the Water Board sector, probably on the basis that it would become a separate chamber within the council. Employers are opposed to centralised bargaining over wages and conditions, arguing that the Water Boards are a very mixed bag in terms of size, circumstances and the problems they face. Some Water Boards are under price pressure from private firms that want to come in and offer the service. Being bound by a centralised wage structure might put these Water Boards out of business. SAMWU, however, state that employer opposition might be lessening as a result of the experience of how the union have dealt with exemptions to the organisational rights agreement.

\section{The Way forward for the Statutory Council Model}

Only two statutory councils have been registered to date, while a number have been established and not stayed the course. Both the registered councils have been moderately successful in what they have achieved, but are still well short of what the unions that initiated the councils want from the process. In light of this, the question is whether the Department of Labour is considering changes to the statutory council model? It should be remembered that the 2002 amendments to the LRA ignored the statutory council model altogether.

The Department does not have a particular strategy regarding statutory councils. However, an idea that has been discussed is that statutory councils should be given most of the rights of a bargaining council and then be placed with bargaining councils on a representivity continuum. ${ }^{37}$ So, once a statutory council reaches a particular representivity threshold it would automatically transform into a bargaining council. The converse would be that once a bargaining council slipped below the threshold it would be downgraded to a statutory council. A variation on this idea is that statutory councils be given the rights of a bargaining council for a certain period, for example, three years. Within this period it must get its representivity level up to the required threshold and then it would be upgraded to a bargaining council.

These proposals are an indication that the Department is grappling with the statutory council model, in particular its failure to integrate a system with some compulsion and a system that is entirely voluntarist. 


\subsubsection{Quasi-Statutory Centralised Bargaining: Contract Cleaning and Security}

Apart from the transport and retail sectors, there is little history of trade union organisation in the tertiary or services sector. Consequently there are relatively few bargaining councils in service industries. Moreover, of the councils that do exist in service industries, a number probably owe their existence more to the fact that employers regard them as useful in regulating conditions of employment in the industry than to trade union organisation. The regional councils regulating the hairdressing trade seem to be a case in point. The council for the contract cleaning industry in KwaZulu-Natal seems to be another.

Contract cleaning, or more correctly, cleaning services, is an operation in which there is a low entry threshold for the emerging entrepreneur wishing to establish his or her business. Consequently there is considerable potential for wage competition, or undercutting, amongst employers. The council probably owes its existence to the fact that in KwaZulu-Natal, unlike in other parts of the country, there has been only one employer's organisation. This association has been relatively successful in uniting its members, as evidenced by the fact that the wages of cleaners in terms of the council's agreement are significantly lower than those negotiated for the rest of the country (see below).

On the other hand the council has played an innovative role in introducing social benefits for cleaners, such as a provident fund and, more recently, a health plan. The success of the provident fund established by the bargaining council led to the establishment of a separate fund for cleaners elsewhere in the country.

The potential for wage competition, or undercutting, amongst employers, creates a strong incentive for employers (particularly large employers) to regulate this competition. This is the case with cleaning services, as already discussed with regard to the bargaining council in

KwaZulu-Natal, and also in security services. Moreover cleaning (outside of KwaZulu-Natal) and security services have adopted almost identical bargaining strategies.

In both instances collective bargaining takes place in a forum constituted in terms of the draft constitution of a yet to be established bargaining council. In both instances the primary reason a bargaining council has not been established is that trade unions have not organised anything approximating 50 per cent of the employees in the sector, In the case of security services, a 2005 verification conducted by the Department of Labour showed that union representation was 33 per cent. However employers disputed this figure, and put the figure at less than 25 per cent. In the case of contract cleaning, union representation may be as low as 12 per cent of the workforce. 
Organised employers have taken the low levels of representivity to mean that any agreement by a council to be established would not be extended to non-parties. ${ }^{38}$ The primary employers' organisations in both sectors are not willing to form a council unless the agreement could be extended, because their overriding concern is to eliminate wage competition and undercutting. As an alternative to the mechanism of extension, when the bargaining forum reaches an agreement the parties in both services have adopted the expedient of asking the Minister to issue a sectoral determination giving effect to its terms.

However, the low levels of representivity need to be seen in context. Even employers concede that employment is highly unstable in both services, with the numbers in employment changing on a daily basis. First and foremost this is because of wage competition: one service provider will lose a contract with a client, and be replaced by another service provider, virtually overnight. As a consequence one workforce is replaced by another, and unless the service provider is able to place them elsewhere, will become unemployed, and unable to contribute union subscriptions. In circumstances such as this unions face an almost insurmountable problem to maintain a stable membership.

Moreover, the legal instrument by which this is achieved, in both services, is the fixed-term contract. The website of the National Contract Cleaning Association (NCCA) provides a precedent of such a contract. This makes it clear that the worker's employment and its duration is totally dependent upon the employer's contract with the client, and that the employee's contract of employment will terminate at any time as and when the client terminates the contract with the service provider. ${ }^{39}$ The worker is further required to undertake to acknowledge that in such event the contract terminates automatically, and shall not be construed as a dismissal.

At the same time the protracted negotiations in 2006, which in both cases resulted in strike action, expose the limitations of the existing bargaining forums and the practice of utilising sectoral determinations to give effect to the outcome of collective bargaining. In the case of cleaning, the parties were unable to reach an agreement, even after a protracted strike. ${ }^{40}$ The Minister, however, went ahead and issued a determination, on terms somewhat more favourable than the wage settlement the employers were offering. The NCCA is now seeking to review the Minister's action in the courts.

38 Notwithstanding the provisions of section 32(3) of the LRA, the provisions of section 32(4) allow the Minister some discretion to extend the agreement. However, in the case of security services, following the 2005 verification, Department of Labour officials indicated there was no possibility of extending an agreement in that sector.

39 See www.ncca.co.za

40 The forum for contract cleaning comprises two employers' organisation and 16 trade unions. Of the unions, only SATAWU and Hospersa have a national presence. 
In the security sector, divisions amongst employers seem to be a more significant factor in the collective bargaining process than in the case of cleaning. There were seven employer associations represented in the acrimonious negotiations that took place in 2006, of which two together represent the majority of organised employers. A total of nineteen unions participated in the forum, of which only South African Transport and Allied Workers Union (SATAWU) had a national presence. After what was probably the bloodiest strike in South Africa's labour history, a settlement was eventually reached. The Minister has been asked to issue a sectoral determination giving effect to the terms of this agreement.

In both services, the primary employers' organisations as well as the unions favour the establishment of a bargaining council. They would also prefer the Minister to extend an agreement negotiated at a bargaining council than to determine wages and conditions of work by sectoral determination. The only constituency that would probably be opposed to the extension of such agreements would be small employers, located mainly in outlying areas. However, many of these employers also do not comply with the sectoral determination. Both employers and unions in contract cleaning and services were frustrated by the failure or inability of the inspectorate of Department of Labour to investigate or resolve breaches of the determination, even when provided with concrete evidence. By contrast, the KwaZulu Natal bargaining council was perceived as relatively effective in procuring compliance.

\subsection{Small Enterprise Owners' and Managers' Perceptions of Labour Statutes, Bargaining Councils and Sectoral Determinations}

\subsubsection{Introduction}

The relationship between labour market regulations and small business has long been a contentious one. Much of the heat in the debate over the allegedly onerous constraints imposed by labour market regulations has been generated by the bargaining councils system, particularly the extension of bargaining council agreements. However, the BCEA and sectoral determinations have also attracted their fair share of criticism. In fact, the promulgation of the new BCEA was held up by the Minister of Labour to allow research to be conducted on its likely impact on small business. Only once it was found that the impact would be limited did the Minister promulgate the Act, although it was closely followed by a Ministerial Determination that varied a number of provisions for businesses with less than ten employees.

The earlier research conducted by Godfrey et al (2006) examined the extent to which bargaining councils were accommodating small business interests in terms of their coverage, representation and exemption systems. However that research did not examine the perceptions of small business people with respect to bargaining councils (or other forms of regulation). One objective for this component of the current research project was to address 
this gap by conducting in-depth interviews. ${ }^{41} \mathrm{~A}$ second objective was to generate qualitative data that would allow engagement with a number of large-scale surveys that inter alia examined a business person's attitudes to labour regulations (see Appendix Two). ${ }^{42}$ In the section that follows we examine the findings.

Given that we adopted a qualitative methodology the sample of small businesses is not large and is by no means representative. A total of twenty-five interviews were conducted at small businesses (with either an owner or a manager). We defined a small business as a firm with less than twenty employees. ${ }^{43}$ The twenty-five businesses were divided into four categories. The first category comprised businesses that had featured in the small business newspaper 'Big News'. Big News has for some years given voice to complaints by small businesses about bargaining councils, to the extent that one could say it has conducted a campaign against the bargaining council system. Including such businesses ensured that the sample included some strongly negative perceptions. A total of five were interviewed, all of which were covered by a bargaining council. ${ }^{44}$

The second category was made up of small firms regulated by a bargaining council. ${ }^{45}$ Ten interviews were conducted; three at party firms, six at non-party firms and one at an unregistered (non-party) firm. ${ }^{46}$ The third category comprised five small firms regulated by

41 When beginning this research project it was recommended that we obtain and analyse the data of the SBP survey. However, SBP was not prepared to make the data available to us (it appears that it is the property of MarkData). SBP would also not let us have a copy of the questionnaire used for the survey. They did, however, answer certain questions about how questions were administered.

42 See, for example, SBP 2005 Counting the cost of red tape for business in South Africa; The World Bank 2000 South Africa: Constraints to Growth and Employment: Evidence of the Small, Medium and Micro Enterprise Firm Survey; The World Bank 2003 Investment Climate Assessment; and, Neil Rankin's analysis of the aforementioned plus the National Enterprise Survey in N. Rankin 2006, The Regulatory Environment and SMMEs: Evidence from South African Firm Level Data DPRU Working Paper No 06/113.

43 There are numerous definitions of a small business in the local and international literature. We did not want to get bogged down in a time-consuming exercise to arrive at a definition for the purpose of this study. The choice of a threshold of twenty employees was, therefore, somewhat arbitrary, slightly larger than the figure given by most bargaining councils, but still well below that used in the National Small Business Act, 102 of 1996.

44 It should be noted that one of these firms had twenty-five employees.

45 The firms were covered by bargaining councils in the building industry, the clothing industry, the road freight industry, the motor industry, and the furniture industry. Each of the councils were asked for a list of registered firms with less than twenty employees. The firms were randomly chosen off the lists and contacted for interviews. All the firms were in the Western Cape. In the case of twenty-three firms the interviews were conducted face-to-face; the remaining interviews were done telephonically.

46 We wanted to interview five party firms and five non-party firms, but in some cases there were no party firms with less than twenty employees. The sample was therefore biased towards non-party firms. 
a sectoral determination. The last category of five firms was made up of those that were regulated only by the BCEA. ${ }^{47}$

The interview schedule focussed on four main areas. We sought, first, to establish the extent of knowledge of labour regulations amongst interviewees. Second, we asked about the impact that labour legislation/regulations had on the businesses, particularly with regard to employment decisions. Third, we enquired whether labour legislation/regulations had any benefits. Fourth, we explored various options with regard to labour regulations, for example, whether the interviewee would prefer to be covered by certain statutes but not others. We also asked about membership of an employers' organisation. The aim in respect of all the above questions was to generate in-depth data on employers' perceptions of labour regulations as well as to compare small businesses covered by bargaining council agreements with small businesses covered by other forms of regulation. In the sections that follow we deal with each of the categories in turn. We then provide a comparative analysis of the findings in respect of all four categories.

\subsubsection{Small Firms Featured in Big News}

The sample of small firms featured in Big News was drawn from twenty-six articles on bargaining councils and small businesses that had appeared in the newspaper over a number of years. However, careful examination of the articles, which generally attack bargaining councils, revealed that only thirteen firms are dealt with in the articles (some appear in more than one article). Nine of these firms were featured (that is, the story was largely about the firm) and four were named only in passing. ${ }^{48}$ We were able to contact and set up interviews at only five of the firms.

Not surprisingly, given that most of the firms had been involved in disputes with bargaining councils, the interviewees had acquired a reasonable knowledge of labour legislation and regulations: most of them were aware of the bargaining council regulations with which their firms had to comply and the deductions they had to make, and some also had some knowledge of the BCEA. Furthermore, all were aware of the statutory social security contributions that they had to make in terms of COIDA and the UIA.

$47 \quad$ The research focussed on the following sectors covered by sectoral determinations: the security, contract cleaning, retail and taxi industries. Firms in the food and restaurant sectors were targeted for the category covered only by the BCEA. In both cases we sought to interview two firms in each sector. Initially we hoped to get lists of firms from the Department of Labour, but the database kept by the Department does not provide the size of firms nor the sectors in which they are located. We, therefore, had to rely on the telephone directory for the selection of these firms.

48 It is interesting to see the way in which Big News has stretched somewhat limited evidence on the bargaining council system across such a large number of articles condemning councils. 
Given that they had some knowledge of labour legislation and bargaining council regulations, all the respondents were able to state how such legislation and regulations impacted on their firms. In this regard the focus of the respondents was mainly on council benefit fund contributions and levies rather than other rights of workers. All stated that the contributions that they had to make to the bargaining council impacted negatively on their finances. This is not surprising; such contributions and the council levies are an addition to labour costs. One of the respondents, however, argued that employers and workers should be able to choose whether they wanted to belong to the council pension fund or another fund. The interviewee was unaware that councils will usually grant an exemption to a firm if it and its employees belong to a pension fund that offers benefits as good as or better than those of the council's fund. The respondents in the clothing sector were particularly upset about the fact that, although the sector has experienced difficulties because of increased imports, the bargaining council levies have stayed the same.

The complaints about the benefit funds were not limited to the contributions that employers have to pay. The interviewees in the building industry and road freight industry also made mention of problems that workers encountered when trying to claim benefits from the funds. One spoke of a widow only getting her husband's death benefit after she and the employer had gone to the TV programme, Let's Fix It. On one occasion the same respondent had to pay the end-of-year bonuses because the council did not make the payment timeously from its Holiday Bonus Fund. He was reimbursed by the council but only some months later.

The same respondent had also been in dispute with the council over arrear benefit fund contributions that had, without his knowledge, not being paid by his bookkeeper (who had embezzled money). While a number of the other creditors had given him time to pay back the various amounts owing, he alleges that the council were completely unsympathetic and inflexible. This has almost led to the closure of his business. It is not surprising that his attitude to the council was one of cynicism. For example, he believed that the bargaining council was "just trying to make money by skimming the interest off the benefit funds".

In addition, two of the respondents in the clothing industry complained about having to pay their workers overtime. In fact, one of them was not paying overtime because he said it would endanger the future of his firm. He also complained about having to pay for public holidays, sick leave and maternity leave, as well as having to comply with onerous dispute procedures. Yet, in one of the many contradictions that emerged in the interviews, the same respondent felt that the bargaining council benefited him because it was instrumental in harmonising labour relations within his firm. Similarly, a respondent in the building industry complained about the costs of having to pay contributions in terms of COIDA, but also acknowledged that it was important because it assists injured workers. This respondent also felt that it was advantageous for his workers to belong to the council's benefit funds. 
Only one respondent (in the clothing industry) claimed that labour legislation and bargaining council regulations were a direct threat to his business. In three other cases the main gripe that respondents had was that the bargaining council was not enforcing its agreement effectively. This meant that unregistered competitors were not being brought to book by the council, which allowed them to compete unfairly. These respondents felt that there should be more rigorous enforcement of regulations. One (in the building industry) argued that, instead of focusing on established builders, bargaining council agents should erect roadblocks on the N2 to stop the 'bakkie builders' laden with casual labour. This was another example of contradictions that emerged in respondent's attitudes to regulation. While strongly criticising various aspects of bargaining councils, respondents then stated that the council was necessary and that the main problem was that regulation was not as comprehensive as it should be. A related complaint by one of the latter respondents was that he had reported non-complying rival firms to the bargaining council but it did nothing about them.

Adding to the contradictions was the complaint by some respondents that their competitors were not complying with bargaining council agreements, while they admitted they were themselves not meeting all standards. One respondent had been convicted of contempt of court for not complying with bargaining council regulations in respect of overtime and payment rates for work on public holidays. He was still not paying the overtime rate because he claimed he could not afford it. At least two other respondents did not register all their workers with the council and a third - who suggested the N2 roadblock - was not registered with a council at all.

Respondents in the building, road freight and clothing industries felt that bargaining councils do not take the interests of small businesses into account. For instance, a respondent in the clothing sector argued that a variety of role players are considered when a sectoral determination is made, but only two are involved in a bargaining council agreement. An interviewee at a small building firm stated that "the big firms use the council to promote their interests and to sort out their problems", while a respondent in the road freight industry felt that "the big transporters were using the bargaining council to choke the small guys".

However, only one of the interviewees had joined a party employers' organisation to make his voice heard in the relevant council. Another respondent (in the building industry) stated that he did not want to belong to the employers' organisation because "it is there to put us out of business and in a downturn they (big firms) compete in our market". Another interviewee said she had not joined an employers' organisation because she was "not approached". A respondent at a clothing firm felt that there was no reason for small firms to join an employers' organisation because they did not have voting rights (incorrect) or representivity (probably the real problem but one that small firms themselves could solve). The response of the interviewee in the road freight industry was the most curious. He stated that he belonged to an employers' organisation, but not one that was a party to the council, and said that "we don't use them; so I don't know what they are doing". 
Three respondents stated that the negative impact of labour legislation and regulations made them reluctant to employ more workers. They therefore kept their workforces to a bare minimum. However, only three of the five respondents in the group had decreased the number of their employees, and in the case of two it was for reasons that had nothing to do with labour legislation and regulations. This tied in with the perceptions of most respondents that there are other factors that are far more threatening to the future viability of their firms than labour legislation and regulations. These include lack of capital, non-payment by creditors, the threat of cheap imports, lack of production skills, and the macroeconomic environment. Comments with regard to the need for greater access to finance and assistance with tender procedures emphasised the importance of factors other than labour regulations.

It is notable that when asked what regulatory system they would prefer all the respondents felt that some form of regulation was needed to protect workers from potentially exploitative employers and to prevent a "free for all". Responses to this question also, to some extent, explained the contradictions that had emerged in some interviewees attitudes toward bargaining councils. In many cases the criticisms of councils related to specific actions or disputes (which the Big News newspaper had highlighted). For example, the attitude of the road freight respondent was strongly influenced by the dispute over the payment of arrear benefit fund contributions. He also complained of lack of enforcement with regard to competitors. However, when asked a more abstract question about the different types of regulatory system he would prefer, he put his specific gripes into perspective and made a more considered judgment: he did not really object to the council system but felt councils should apply more discretion in the enforcement of their regulations. Yet, contradictions emerged again when he was asked whether he had applied for an exemption, which is generally the way in which a council can apply discretion. He replied ambiguously that "he considered it, but they would not listen to (him)".

Two of the remaining four respondents in this category also opted for regulation by a bargaining council. For example, one respondent, who had probably been the most strident critic of councils, stated that he was "not anti-bargaining council" but that the council should be more representative of small firms. He, along with another interviewee in the clothing sector, believed that regulations should provide more scope for discretion to be exercised regarding firms' circumstances. Specifically, there should be lower labour standards for small firms. Another respondent suggested that firms should pay benefit fund contributions according to a sliding scale that took account of their size.

The remaining two respondents expressed a preference to be regulated only by the BCEA. Both argued that a second tier of regulation, which a bargaining council agreement constituted, was unnecessary. However, contradictions again emerged. One of these respondents was a party to a bargaining council and one of the strongest supporters of councils. 


\subsubsection{Small Firms Registered with Bargaining Councils}

Registration with a bargaining council corresponds with greater knowledge of these regulations as well as of labour legislation more generally, although knowledge of the latter tended to be confined to the contributions made in terms of the UIA and COIDA. Two of the respondents said they relied on their bargaining council to keep them informed about labour legislation. When it came to bargaining council agreements, respondents were almost all aware of their obligation to make contributions to benefit funds, and also knew that they had to comply with minimum wage rates, the overtime rate, leave conditions and annual bonus requirements. In most cases, however, respondents were quite vague with regard to the details and one got the impression that wage clerks and bookkeepers would be better informed. Importantly, most respondents did not appear to be aware that they could apply for exemption from part or all of a bargaining council agreement.

The knowledge of bargaining council regulations is partly explained by the fact that there is more effective enforcement by councils than by the Department of Labour (DoL). This applied to parties and non-parties. Six of the respondents have never been visited by a DoL inspector, two were not sure but could not recollect an inspection, one stated the firm had not been inspected in the last two years, and the tenth had been visited by a DoL inspector six years ago. In stark contrast, most of the respondents had been visited by a bargaining council agent. One stated that his firm was visited as often as once a month, another said once a year, and a third said a visit occurred in response to a request from himself. Even where inspections had never taken place, monitoring by the council was evident. The respondent in the furniture manufacturing industry stated that he had never been visited by a council agent but that the council nevertheless picked up that he was not paying his levies and summoned him to a hearing. He was made to pay his arrears.

The majority of respondents believed that labour legislation did not have much impact on their firm, but most stated that bargaining council agreements had a negative impact. As with the firms in the Big News category, the most frequent complaint about bargaining councils was with respect to council levies and benefit fund contributions. Respondents stated that these added significantly to their wage bill. The perception that the benefit funds provided workers with rather poor benefits heightened their negative views. Respondents complained that the interest which council benefit funds earned was "criminally" low. At least some workers appeared to share their employer's concerns: a respondent in the motor industry stated that some of her workers had threatened to become 'causal' if she deducted money from their wages for the council's pension fund.

Two respondents also complained that bargaining councils are too intrusive. They argued that they no longer had any control over their firms because the respective councils interfered too much in their affairs. There were also various complaints about other conditions regulated by council agreements. Some respondents complained about the wage increases, while annual 
leave and leave pay was also a bone of contention. A respondent in the clothing industry felt that maternity leave was too long and objected to paying workers for a public holiday that fell on a weekend. She also complained about restrictions on overtime, as did the respondent in the building industry. It was also alleged that workers were not happy with aspects of the bargaining council system. One respondent claimed that his best workers do not like the fact that bonuses are spread amongst all employees.

Two factors tended to balance out these negative perceptions. First, eight respondents stated, albeit sometimes grudgingly, that their bargaining council offered some advantages. The most important was advice on labour legislation, standards and procedures that councils gave to firms, which included a printed guide that some councils regularly distribute. Respondents also mentioned that they frequently phoned their council for advice and clarification regarding labour legislation or the council's regulations. One described bargaining council agents as "very, very helpful", while another said that a council agent would come out to her firm's premises to explain aspects of the council's agreement for her. In addition, three respondents mentioned that an advantage of the council system was that they did not need to negotiate directly with unions. For example, the respondent in the motor industry felt that the council regulated his labour relations, obviated the need for him to negotiate with trade unions, and helped the company to do on-line reconciliations. Another respondent stated that the bargaining council was an independent body that sets rules and standards, thereby removing the focus from the workplace: "We can tell our workers that the BC has made the rules, not us".

The second factor, which pointed to indirect support for bargaining councils, was the perception that councils should be enforcing their agreements more rigorously. Two party firms and two non-party firms believed that enforcement was not satisfactory, which resulted in noncompliant firms having an unfair advantage. A respondent in the building industry complained that the latter firms can take on big, urgent jobs because their employees worked more than the maximum allowed overtime. A respondent in the clothing sector said it irked her "hugely" that the council was not policing its own regulations properly, with the consequence that one of her rivals (who did not comply with regulations) had lower labour costs. Angering her even more was the fact that she had reported the rival to the council but to her knowledge no action had been taken.

Contradictions emerged in discussing the consequences of labour legislation and regulations. All the party firms stated that labour legislation and bargaining council regulations had made them reluctant to employ more staff. However, two of these respondents had increased their workforce by ten and eight people respectively. The respondent in the furniture industry had decreased his workforce by eleven, but the reason he gave for this was that employees had been stealing from him, that is, it had nothing to do with labour legislation or regulations. He had also managed to get rid of these workers despite his allegation that dismissal procedures were onerous. 
Non-party firms were more concerned about bargaining council regulations than labour legislation. Six respondents stated that the former had influenced their decisions to take on more staff. One had instead employed 'casual' labour, because such workers were easier to dismiss if they under-perform, while another had contracted with homeworkers in order to avoid paying bargaining council contributions. A third respondent said that he preferred to employ workers on three-month fixed-term contracts. However, despite the above responses, all three firms had increased their staff. Further, only two of the remaining seven firms had decreased their workforce, and only one of them directly blamed bargaining council regulations for this reduction.

None of the respondents (parties and non-parties) identified labour legislation or bargaining council regulations as the biggest threats to their firms. Instead, increased competition from cheap imports, the cyclical nature of demand, and access to finance were mentioned as the major threats. In addition, two respondents noted that the only threat from bargaining councils was that they were not enforcing their agreements properly, which meant competition from unregulated firms.

When asked which form of regulation they preferred, five of the ten respondents indicated the bargaining council system. A respondent in the motor industry said that "the more regulation the better, as it cleaned up the industry". The BCEA on its own was therefore not sufficient. A non-party in the clothing industry stated that they would get a better deal through bargaining council negotiations than they would from a sectoral determination. The bargaining council was also seen as more professional and user-friendly than the DoL (getting through to the DoL by telephone was seen as a major problem).

One party respondent was strongly opposed to the bargaining council, describing it as "useless". He wanted to leave, but was unclear how he would achieve this, referring at one point to being exempted and at another to being subjected to less strict standards. He also felt that small businesses should not have to adhere to the same legislation as big firms, but did not provide details as to how this would be done. Surprisingly, he remained a member of the party employers' organisation, even though he did not participate in it and was against the council.

On the other hand, three of the non-party respondents that favoured regulation by a bargaining council did not want to join a party employers' organisation. In fact, five of the non-party firms were not even aware of the existence of an employers' organisation. A respondent in the clothing industry used to be a member of the employers' organisation but withdrew because she got the "worst service imaginable". A sixth respondent felt that joining an employers' organisation would be just "another bother". 
Two non-party respondents wanted to be exempted from bargaining council regulations. Another two non-party respondents stated that they would prefer to be regulated by a sectoral determination, because this would mean that they would not have to pay levies. None of the respondents showed a preference for bargaining at firm-level with a trade union.

Leaving aside the differences identified above, all ten firms indicated that some form of labour legislation was necessary to stop employers from exploiting their workers.

\subsubsection{Small Firms Regulated by a Sectoral Determination ${ }^{49}$}

The respondents covered by bargaining councils had some broad knowledge of labour legislation and regulations, but respondents covered by sectoral determinations were largely ignorant. In fact, three of the five respondents were unaware that they were regulated by a sectoral determination. Remarkably, two of the latter respondents had been visited by a DoL inspector since the sectoral determination had been promulgated but were still unaware of it. Two respondents in the retail industry were somewhat better, in that they were vaguely aware of the sectoral determination regulating the sector. One referred to a "body that controls retail and sets minimum wages and standards", while the other referred to a "booklet issued by the DoL that sets out the legislation specifically for the retail industry".

Where there was knowledge it was confined to the contributions that need to be made in terms of COIDA and the UIA. Most respondents were also vaguely aware of a minimum standards statute but did not know that this was the BCEA. One respondent simply referred to "a big poster issued by the DoL that I put up in the back", but seemed to have no knowledge of its contents.

Surprisingly, given their limited knowledge, all but one respondent claimed to be complying with labour legislation and regulations. The one interviewee who did know something about the sectoral determination and the minimum wage was the non-complier. He was not complying because he claimed that he could not afford to pay his workers the prescribed wage.

As one would expect, when asked about the impact that labour legislation and regulations had on their firms the respondents limited their somewhat vague replies to labour legislation in general. Two of the respondents believed that labour legislation did not have a major negative impact on their firms. Of the rest, one respondent felt legislation impacted on the productivity of his workers because they abused sick leave and he was powerless to stop them. He did not explain why the legislation left him powerless. Together with another respondent, he

49 There were five firms in this category: three in the retail sector, one in the taxi industry, and one in the contract cleaning industry. 
felt that labour legislation made it difficult to fire under-performing workers. A respondent in the taxi industry stated that contributions in terms of COIDA put an unnecessary financial burden on the firm, particularly since most of his staff did administrative work and were not exposed to any danger. The firm did not employ taxi drivers directly: they were hired as independent contractors. It is, however, difficult to comprehend how contributions for the small administrative staff at the firm could be onerous.

One respondent turned the focus away from labour legislation to the DoL. He stated that dealing with the DoL was extremely time-consuming and this translated directly into a loss of money. He complained that he struggled to get through to the DoL on the phone: "You can write off a day if you have to deal with them". Neither did the DoL officials provide him with adequate support and advice once he got through to them. He struggled to register and de-register employees for unemployment insurance, and had such difficulty claiming UIA maternity benefits for pregnant employees that he eventually gave up and paid for maternity leave himself.

Perceptions of labour legislation had a limited influence on decisions regarding employment. Three of the respondents had increased their staff complement, one had reduced the number of employees, and one had kept his workforce the same. However, the respondent who had reduced his staff did so because of increased overheads rather than labour legislation. The respondent whose workforce stayed the same alleged that this was in part because labour legislation was so cumbersome. Another respondent felt he exercised more care when recruiting staff, since it was so difficult to dismiss workers once they were permanently appointed. He had nevertheless increased his workforce by five people.

Balancing out the above, to some extent, were three respondents' views that labour legislation had some benefits. Two felt legislation provided an independent set of guidelines for both workers and employers that assisted when there was a dispute. The third respondent stated that labour legislation made for "clean, open relationships" between workers and employers.

None of the other respondents identified labour legislation as a major threat to their business. Two respondents in the retail sector saw demands made by shopping centre landlords as a much more serious threat. ${ }^{50}$ One claimed that the landlord's intention to extend shopping hours until 10 p.m. would leave him in a quandary, because the BCEA did not allow his workers to work long shifts on a regular basis and he could not find people prepared to work split shifts. The other respondent claimed that the landlord was escalating rent "in no relation to actual turnover", and that as a result many small businesses in the centre were closing down. Her rent was, furthermore, not reduced when renovations in the building decreased her

$50 \quad$ This appears to be a major problem: see, for example, 'The little guy gets shafted', Mail \& Guardian, May 18 to $24,2007$. 
turnover. She complained that only national chain stores could negotiate favourable rents with the centre's landlord. Small retailers were powerless. When lessees of the shopping centre had formed an association to stand up to the landlord they had been evicted. Another two respondents mentioned lack of capital and unreliable staff (who were absent and/or stole from their employer) as major threats. A lack of suitably skilled staff was also stated to be a threat. One respondent in the taxi industry identified inadequate enforcement of licensing regulations as a major threat because 'pirate' taxis had an unfair advantage over him and robbed him of business.

The different regulatory options (that is, a bargaining council, a sectoral determination or just the BCEA) had to be explained to respondents because of their lack of knowledge. Even after explaining the different options one of the respondents was unable to answer the question. The remaining four respondents preferred the status quo, which we assume meant being regulated only by the BCEA, because most were ignorant of the fact that they were regulated by a sectoral determination. None of the latter four respondents chose a regulation-free environment. All felt that labour legislation was necessary to protect workers from employers.

\subsubsection{Small Firms Regulated only by the BCEA ${ }^{51}$}

Respondents in this category had very limited knowledge of labour legislation. All were aware of the contributions and deductions that they had to make in terms of COIDA and the UIA, but only one respondent specifically mentioned the BCEA and was aware of some of its provisions. The latter respondent also knew something about dismissal procedures. Another respondent also had some knowledge of dismissal procedures, as well as leave and notice requirements, but she did not know that the latter were in the BCEA. Two of the respondents had no knowledge of the BCEA; they used standard contracts to regulate the terms and conditions of their staff.

Two respondents stated that labour legislation had no impact on their business. This is not surprising since, as far as they were aware, they complied only with COIDA and the UIA. The remaining respondents were concerned mainly with the dismissal requirements, complaining that these were onerous and took up a lot of their time (two had been taken to the CCMA over dismissals). One respondent also felt that dismissal procedures were costly because she had to send warnings by telegram to workers who were absent without leave. Another complaint was that the dismissal procedures lowered productivity because workers could slack off with impunity.

$51 \quad$ Two of the firms in this category were located in the food industry and three were located in the restaurant sector. 
A respondent also identified sick leave, and abuse of sick leave, as problems because he had to make contingency plans to staff his restaurant. Another respondent complained bitterly about complicated Unemployment Insurance Fund (UIF) forms. She invariably had to help her staff fill these in as some of them had struggled so much to claim UIF that they had given up.

Two respondents argued that the impact of labour legislation had forced them to reduce their staff. One said that she was now less likely to employ new people, while the other was using workers supplied by a labour broker to avoid the "hassle factor" of directly employing staff. Another respondent identified social security contributions as a major burden, but she had increased her staff complement despite this concern. However, the above claims should be treated with caution given the lack of knowledge of labour legislation identified at the outset.

As with the other categories, some respondents believed that labour legislation did have some benefits. One respondent believed that labour legislation provided her with parameters within which to operate, while another felt that the legislation protected both himself and his workers. There were also complaints about inadequate enforcement of legislation. One respondent was sceptical about the political will of government to enforce its own regulations. She felt that the DoL focused on formal "white" businesses but turned a blind eye to the practices of "black" firms located in townships. Another respondent felt the DoL was "toothless", because it failed to protect vulnerable workers in the restaurant industry, which resulted in restaurant owners treating their staff badly.

Most respondents identified factors other than labour legislation as the main threats to their firms. These included finding premises where landlords did not continuously push up the rent, lack of capital, fierce competition, the seasonality of markets, and various fees that local municipalities and other agencies demanded.

In response to the question as to the type of regulatory regime respondents would prefer, four opted for the status quo, that is, regulation only by the BCEA. However, two added that if they were forced to choose an alternative they would favour regulation by a bargaining council. They believed that employers would be able to negotiate a better deal for themselves than they would get from a sectoral determination. Only one respondent was in favour of a sectoral determination, because he believed it would mean not having to negotiate with trade unions. None of the respondents were in favour of having no regulations. They all felt that employees needed to be protected from unscrupulous employers. However, one respondent contradicted herself by stating that she did not want to be covered by any regulation and wanted a less onerous dismissal regime. Another three respondents wanted a special dispensation for small firms. 


\subsubsection{Comparative Analysis of Small Firm Interviews}

A number of points of similarity and difference emerge when one compares the perceptions of interviewees in the four categories. Common to most respondents was poor knowledge of labour legislation and other labour regulations. However, respondents covered by bargaining councils had at least some knowledge of legislation and bargaining council agreements. In contrast, the knowledge of respondents covered by a sectoral determination or only by the BCEA was generally very bad. In fact, they were so ignorant that there is a question mark over many of their subsequent statements regarding the impact labour legislation and regulations had on their employment decisions and the alternative regulatory system they would prefer.

Detailed knowledge was restricted to the payments that needed to be made in terms of COIDA and the UIA, and in the case of bargaining councils' contributions to benefit funds and the council levy. If there was knowledge of employment conditions it was often related to specific incidents (that is, contraventions or disputes) regarding one or more conditions. This was the case with the Big News respondents. It was also the case with respondents not covered by bargaining councils. With regard to the latter, it is interesting to note that rights regarding dismissal featured much more prominently, mainly because of the problems they had experienced.

One reason for the better knowledge of labour regulations on the part of the firms, covered by bargaining councils, is the more frequent inspections and monitoring that they receive. Furthermore, bargaining councils are perceived as being much 'closer' and more accessible in terms of getting advice and assistance. On the other hand, the Department of Labour came in for a great deal of criticism from respondents (mainly those covered by the BCEA or a sectoral determination) regarding its accessibility and performance in response to enquiries. In some cases it seemed that this was of greater concern to respondents than legislation or regulations.

The answers given by respondents revealed many contradictions. This is to be expected given that most respondents had quite a poor knowledge of labour legislation and regulations. It implies that owners and managers do not systematically measure or even think about the extent of the impact of labour legislation and regulations on their firms. Where there is some knowledge it is often very specific, that is, a provision that has given rise to a problem. These problematic provisions then coloured respondents' attitudes to labour legislation and regulations more generally. Poor knowledge or very specific knowledge often led to contradictions when questions were asked about costs or benefits of labour legislation and regulations as well as alternative regulatory regimes. Although no respondent stated it in these terms, the following is an example of the sort of contradictions that emerged: 
I am in favour of bargaining councils, but I want greater flexibility for my firm and I can't be bothered to apply for an exemption. So I am not complying with onerous aspects of the bargaining council agreement, but the council must ensure that my competitors do comply.

With regard to the negative aspects of labour legislation and regulations, respondents covered by bargaining councils generally found little fault with labour legislation and focused on bargaining council regulations. The council benefit funds attracted by far the most criticism. This criticism had two aspects. On the one hand, interviewees complained about the added cost of these benefits and, on the other hand, many also alleged that the benefits workers received from the funds were poor and/or it was sometimes difficult for workers (or their dependants) to access the benefits. Other employment conditions were also mentioned - restrictions on overtime and the overtime rate, annual leave and leave pay, sick leave, maternity leave, etc. - but none of these were of the same order as the comments in respect of the benefit funds.

Two points need to be made about all these complaints. First, they are perceptions only and cannot be objectively measured and evaluated. They are, therefore, open to the criticism that it is very easy for respondent to complain about various provisions without them necessarily being problematic. Second, it is evident that some complaints were rooted in managerial incapacity rather than in the provisions themselves. An example is the respondent who complained that he was powerless to stop abuse of sick leave by workers. It was not apparent why he was made powerless by labour legislation. If he took steps to discipline workers that were abusing sick leave then it is likely that the problem would be solved one way or another. This does not mean that the responses of interviewees have no validity. One must, however, bear the above points in mind when considering the findings.

A further point needs to be made to put the complaints about benefit funds and other provisions in perspective, namely that labour legislation and regulations have benefits. This was acknowledged by a large proportion of the respondents, particularly those covered by bargaining councils. However, it is impossible to measure these perceptions to establish whether the value of the benefits balances out the cost of the provisions complained about. What is important, given the methodology adopted in this study, is the impact that such perceptions have on decisions made by respondents, particularly with regard to employment. Some respondents believed that labour legislation and regulations had little impact on their firm and did not influence their decisions about employment. Most, however, stated that labour legislation and regulations did impact on decisions about employment. But it is clear from the answers given that labour legislation and regulations were only one of a number of factors that respondents took into account when deciding on employment levels. Labour 
legislation and regulations were certainly not perceived to totally restrict employment: a number of respondents had increased employment since establishing their firms. Legislation and regulations were also not the main factor leading to decreased employment. Where this had taken place, it was usually for reasons other than labour legislation and regulations. Almost every respondent identified a number of factors as more threatening to their firms than labour legislation and regulations. The latter are but one consideration amongst many that the owners and managers of small firms take account of when making employment decisions.

The main benefits that labour legislation and regulations were perceived to have for firms was that they restrict competition on the basis of labour costs by setting standards beneath which firms should not go. This limit gives firms stability and provides for sound industrial relations. Another benefit is that most firms do not have to negotiate directly with unions.

Related to the question of benefits is the issue of ineffective enforcement. This is one of the more surprising findings to emerge from the interviews. Even amongst the Big News respondents, most of whom were supposedly opponents of councils, this was raised as a key complaint. It strongly suggests that large party employers are not the only ones that want standards extended to all firms. Small non-party firms registered with councils are just as concerned that their competitors are made to comply with minimum standards. In fact, such firms appear to be more at risk from competition from unregistered firms. Hence, the serious concern that emerged was over the ability of councils to effectively police their agreements. While this point was generally made as a complaint about councils, it can be interpreted as indirect support for the bargaining council system. In effect, respondents were saying that they did not have a major problem with councils as long as they ensure that all firms comply with their agreements. A similar view was expressed by firms covered by sectoral determinations and the BCEA.

Despite the contradictions that often emerged when respondents spoke about the problems and benefits flowing from labour legislation and regulations, every respondent agreed that labour regulation was necessary. The need for some floor of rights and standards therefore appears to be uncontentious. Furthermore, there was considerable support for bargaining councils, the form of regulation that generally sets the highest labour standards. On the other hand, even when there was support for bargaining councils, there was also a plea for more flexible regulations that are sensitive and responsive to the concerns of small firms. This was a plea that also arose at firms not covered by bargaining councils. And it was repeated with regard to the regulatory regimes firms would prefer, which generally pointed to a more flexible system. This is not a surprising finding. For over a decade flexibility has been the mantra of employers, and especially of small employers. What is surprising is that employers and managers at small firms do not link their desire for more flexibility with the mechanisms in the legislation that provide for flexibility. 
The most obvious mechanism is the exemption or variation system. Earlier research by Godfrey et al (2006) showed that the bargaining council exemption systems are working relatively well. The research also showed that the procedures for applying for an exemption do not appear to be complex or onerous. Yet none of the respondents appeared to see applying for an exemption as a practical option. In part this must be the result of the level of ignorance about legislation and regulations, including exemption systems. An education campaign would probably help in this regard. But poor knowledge is probably not the only explanation. The question is: Why do small firms that want some leeway with regard to regulations not want to use the mechanisms that are designed to give them that leeway? This paper does not provide the answer to the question. More research is needed to establish the answer. It is anomalous that allegations about the negative impact of labour legislation on small firms continue to be made at the same time that mechanisms in the legislation, designed to address these criticism, are not being used.

The second mechanism for achieving flexibility is less direct. The new LRA sought to deal with the problems small firms experienced with bargaining councils by opening up the way for them to participate in councils. It was envisaged that greater participation by small firms would lead to regulations that better accommodated their concerns and interests. But the interviews indicate that small firms are not pursuing this option, and the main reason appears to be that they do not place much faith in the existing employers' organisations. They are either not aware of them, have no interest in participating in them, or have been put off by them. What do employers' organisations need to do to make themselves more attractive to small firms? Again, it is a question that requires more research. Previous research on bargaining councils has examined employers' organisations only in passing.

\subsection{The Non-Statutory System}

\subsubsection{Non-Statutory Centralised Bargaining}

Not all multi-employer centralised bargaining takes place in bargaining and statutory councils. Two major industries are covered, or partially covered, by non-statutory centralised bargaining arrangements: mining and automobile manufacturing; and there is at least one other such forum, in the pelagic fishing sector. We deal with each of these in the section below.

\section{Mining}

Centralised bargaining in the mining industry dates back to 1915, when the Chamber of Mines was first mandated by its members to negotiate with trade unions. The centralised bargaining arrangement has gone through considerable change and development since then. In fact, its most striking feature is said to be its adaptability. Probably the biggest change was brought 
about by recognition of the National Union of Mineworkers (NUM) in 1983 and subsequent collective bargaining with the union along with the other unions.

The centralised bargaining forum is not a statutory body; it exists and operates by virtue of agreements between the participants and established practice, as adapted from time to time. As Frans Barker, the Director of Industrial Relations at the Chamber, notes, it is not a centralised bargaining forum in an institutionalised sense: "We just get together and do things". 52

The Chamber of Mines is the only active employers' organisation that is registered for the mining industry and undertakes collective bargaining only on behalf of its gold and coal mining members. ${ }^{53}$ As from 1996 negotiations for the 'category 3-8' bargaining unit were conducted as parallel processes in one central forum, that is, there were de facto two forums, one for gold and one for coal. However, the parallel processes were formally separated in 2005 with the establishment of two distinct forums.

The centralised bargaining arrangement is highly representative of the gold mining industry (69 per cent in 2002 and possibly as high as 75 per cent in 2006) but is not representative in the coal industry (36 per cent in 2002), that is, total employees of the Chamber's gold and coal members as a proportion respectively of all employees in the gold and coal mining industries. ${ }^{54}$ Given that as at 2002 there were a total of thirty-eight gold mining operations and 199355 employees, and sixty-three coal mining operations and 47960 employees, this means that the bargaining arrangement covered about 137554 gold mining workers and about 17265 coal mining workers.

$52 \quad$ As there is not an institutionalised forum it has no staff. The Chamber provides the venues for meetings and negotiations and pays for meals. Any secretarial functions are in all likelihood performed by the Chamber of Mines.

53 While the Chamber performs collective bargaining only for its members in the gold and coal sectors, it has other members that administer mines in the gold, coal, diamond, platinum group and base metal extraction industries. Three of its members are themselves associations and they, in turn, have members in aggregate and sand quarrying, brick-making and alluvial diamond mining. The gold and coal members of the Chamber that are subject to the Chamber's collective agreements pay a separate collective bargaining fee in addition to their ordinary subscriptions

54 In 2003 the Gold Producers' Committee represented a total of five mining groups which in total own twenty-eight mining operations. They are Ashanti (nine mines); Gold Fields (seven mines); Harmony (six), Freegold JV (five mines) and Placer Dome Western Areas Joint Venture (one mine). The Colliery Committee represented seven coal companies which in total own twenty-seven collieries. They are AfriOre (SA) (one colliery); Anglo Coal (nine collieries), Eyesizwe Coal (three collieries); Ingwe Collieries (three collieries); Kangra (two colliery); Kuyasa Mining (one colliery); Xstrata Coal (eight collieries). 
As indicated above, not all gold and coal companies are Chamber members and covered by the centralised bargaining arrangement. ${ }^{55}$ But many of the mines that are outside of the ambit of the Chamber's bargaining would be covered by company or mine-level collective bargaining. ${ }^{56}$ Furthermore, not all the gold and coal members of the Chamber are covered by the collective bargaining (although most are). Currently BHP Billiton is a Chamber member but is not covered by the coal agreement; SASOL are also outside the collective agreement. ${ }^{57}$

A host of unions are active in the mining industry and a lot of them have recognition agreements with specific mining firms. However, the Chamber engages in bargaining with only four unions. These are NUM, UASA, Solidarity and the SA Equity Workers' Association. Their levels of representation are indicated in Table 3 (note that figures are for 2004):

Table 3: Levels of Representation of Unions Recognised by Chamber of Mines

\begin{tabular}{|l|c|c|}
\hline Name of Trade Union & Representation on gold mines & Representation on coal mines \\
\hline $\begin{array}{l}\text { National Union of } \\
\text { Mineworkers (NUM) }\end{array}$ & $67.7 \%$ & $65 \%$ \\
\hline $\begin{array}{l}\text { United Association of } \\
\text { South Africa (UASA) }\end{array}$ & $10.4 \%$ & $12.9 \%$ \\
\hline Solidarity/MWU & $1.9 \%$ & $6.0 \%$ \\
\hline $\begin{array}{l}\text { SA Equity Workers' } \\
\text { Association (SAEWA) }\end{array}$ & $0.4 \%$ & No representation \\
\hline
\end{tabular}

Source: Chamber of Mines

There are three bargaining units, namely 'category 3 to 8 employees', 'miners and artisans', and 'officials'. This categorisation is used amongst most of the larger firms in the industry. The first category refers to the relevant job grades and includes both 'staff' and 'non-staff' employees. This is numerically the largest bargaining unit and comprises semi-skilled and skilled workers up to a certain grade. The second category comprises mainly (1) workers in certificated blasting and ancillary jobs, and (2) artisan and allied jobs, that is, blue collar workers above a certain grade (it is called the 'miners and artisans' unit but was previously known as the 'union men' unit). The 'officials' category comprises employees categorised

$55 \quad$ For example, Durban Roodepoort Deep is a major mining firm that is not a member of the Chamber. On the coal side, bargaining has historically been much more fragmented, with a large number of companies not joining the Chamber.

56 The majority of the large platinum producers are members of the Chamber. The Chamber has never conducted collective bargaining on behalf of its platinum members, but company-specific arrangements are widely in place and collective bargaining cover in the sector is extensive. The two major corporate employers in the diamond sector are De Beers Consolidated Mines and the Trans Hex Group, both of which are Chamber members. De Beers has about 10000 employees at its nine South African sites, while Trans Hex has some 1200 employees at six SA sites. NUM is recognised at both companies and bargains with them at company level.

57 In the case of mergers it is sometimes unclear where the new entity stands in terms of the collective bargaining, that is, where one of the firms was party to the collective agreement and the other was not (for example, the recent merger of Kumba, which had been covered by collective bargaining, and Eyesizwe, which was not covered. 
as officials and who are in occupations graded BU and CU (inclusive), that is, supervisory employees above a certain level and white collar employees (Spowart, 2004).

The number of employees employed by the gold and coal Chamber members in these units are as follows:

$\begin{array}{lll}\text { Category 3-8 } & \text { Gold }-113587 & \text { Coal }-10942 \\ \text { Miners and Artisans } & \text { Gold }-10870 & \text { Coal }-2731 \\ \text { Officials } & \text { Gold }-14839 & \text { Coal }-2787 \\ \text { Total } & \text { Gold }-139296 & \text { Coal }-16460\end{array}$

Source: Chamber of Mines

Over time shifts have taken place with regard to the levels at which bargaining takes place for the different bargaining units. Some time ago a process of decentralisation of bargaining took place with regard to the 'officials' category: it came to be bargained at mine level whereas previously it had been dealt with centrally. It seems that this was formalised by agreement in 1999. The 'miners and artisans' category seemed to be drifting the same way with some issues being bargained at mine level, particularly in the coal sector. However, as from 2003 a process was started to consider some form of integration of the units. So the decentralisation process was reversed just prior to the 2005 negotiations, when it was agreed that bargaining for all three units (which had previously been in separate forums) would take place in a unified forum (but with goal and coal negotiations being split).

Prior to 2005 each unit had its own requirements as to the level of representativeness required in order for a union to be afforded recognition in a bargaining unit on a mine (although no gold or coal mining firm follows a 50 per cent plus one approach). So, recognition is afforded on a mine-by-mine basis once the union satisfies the representivity criteria of the mine concerned. Once a union has been afforded recognition for its members in a bargaining unit at one of the mines, it is afforded entry to the relevant bargaining forum at the mine.

Not all the unions are recognised by the Chamber for all three categories: NUM is the only union recognised for the first category; all four unions are recognised for the second category; and only NUM and UASA are recognised for the 'officials' category. So NUM is the only union recognised for all three categories.

There has been considerable change to bargaining arrangements in recent years. Prior to 2005 bargaining in respect of the three bargaining units was conducted separately in different forums. The forums for "category 3 to 8 employees" (gold and coal) and "miners and artisans" (gold) were situated at the industry level. Collective bargaining in respect of "officials" in both the gold and coal industry had gravitated to company level. However, as indicated above, this changed in 2005. But even in the central forums, not all issues were dealt with centrally. In 1996 two-tier agreements were concluded with all the unions to regulate what matters were 
to be negotiated at industry level and what matters were to be negotiated at company level. In terms of these agreements bargaining over basic wages and conditions of employment would take place only at Chamber level. ${ }^{58}$ Bargaining over organisational, operational and workplace issues is at mine or company-level. ${ }^{59}$ However, it has frequently happened that framework agreements are formulated and agreed to at the central level which set parameters for negotiations at mine or company level.

For employers it is important that unions do not have two bites at the cherry. There is only one central actual wage increase. Any issue that has direct cost implications must be bargained centrally. For example, living-out allowances were being bargained at some mines, but in 2005 it was recognised that these had direct cost implications and since then the allowances are dealt with centrally. However, increasingly, the bargaining forum has ceased to be a structure within which the employers conclude a single substantive agreement with majority unions in respect of the bargaining units. The de facto situation is that the Chamber has more than once simply provided a forum in which its members reach separate or individual deals with union parties, particularly in respect of wage rates. Accordingly, the agreements that are reached frequently reflect different provisions for different companies, particularly in respect of wage rates (that is, actual basic wage rates are negotiated on a company-by-company basis). When it comes to non-wage issues, however, there is usually more uniformity in outcomes at the central level.

The criticism has been levelled that the above approach to negotiations has resulted in fragmentation and in a complex and protracted process that is often confrontational. These developments were one of the reasons for launching an investigation of future bargaining options (see below). However, according to the Chamber "the countervailing view is that a 'one size fits all' approach is not appropriate in accommodating business circumstances and imperatives that are often vastly different. The flexibility that the system permits is, by that view, an advantageous feature. Certainly, the Chamber system has achieved a remarkable degree of labour peace over a lengthy period." The flexibility is probably justified in the gold mining sector because it allows bargaining to take account of the fact that the sector as a whole is in decline and has a number of marginal mines that can be closed down by a small rise in costs.

As noted above, the centralised bargaining arrangement exists because of established practice and a web of agreements. Besides the many agreements there has been a host of other initiatives to address wider socio-economic and industry concerns. The latter include HIVIAIDS summits; retirement summits; the Mining Charter; and a NEDLAC process on the future of the

$58 \quad$ The agreements do allow that if special circumstances are present the parties can agree that negotiations on these issues take place at mine or company level.

59 The setting up of company and mine level structures for bargaining and consultation on workplace issues at those levels is not a matter that has been regulated at the central forum. Each company has its own agreements with the unions on the type of structures and forums that are established at the workplace. 
gold mining industry. To give a sense of what the bargaining arrangement has achieved over the last ten years, some of the most important developments are listed below:

- September 1996: Two-tier agreements with all unions regulating what matters are negotiated at industry level and what matters are negotiated at company-level.

- July 1997: Chamber and all unions conclude multi-year wage deals, the first instances of such agreements for gold and coal.

- December 1999: Agreement with UASA to devolve bargaining in respect of 'officials' to company/mine level.

- April 2000: Consolidation of the two "recognition units" within the 'miners and artisans' bargaining unit (previously called the 'union men' bargaining unit).

- August 2001: Industry framework agreements for affording NUM recognition in the 'miners and artisans' and 'officials' unit.

- August 2003: Agreement with NUM that the Chamber and all recognised unions would consider some form of integration of the existing bargaining units and improvements to bargaining arrangements.

Below is a list of some of the agreements that the forum has reached since 1996:

- 1997: Agreement on industry principles regulating health care.

- 1997: Agreement on principles and a process for the review of job grading systems.

- 1998: Gold Mining Summit, resulting in a six weeks' moratorium on retrenchments and the formation of the Gold Crisis Committee and other initiatives.

- 1999: Chamber and NUM agree to conduct joint lobbying and protest action about the effects of the sale of gold by the IMF and central banks.

- 1999: Agreement on a medical incapacity benefit for 'category 3 to 8' employees, which was increased in 2001.

- 2001: Agreement on the attainment over the course of the agreement by most companies of a minimum underground wage rate of $\mathrm{R} 2000$ per month.

- 2001: Comprehensive agreement on affirmative action in appointments, training and development, retention of skills and employment of women.

- 2003: Agreement on the attainment over the course of the agreement by most companies of a minimum surface wage rate of $\mathrm{R} 2000$ per month.

- 2003: Framework agreement on women in mining. 
- 2003: Framework agreement of principles relating to attainment of the accommodation objectives in the Mining Charter.

More recently, there has been an accommodation agreement regarding employees living in hostels and an agreement on health care for dependants (such health care is free for mineworkers but for dependants the agreement provides for contributions on a 50/50 basis).

In addition, three industry retirement funds have also been established by way of Chamberlevel agreements. ${ }^{60}$ They are the Mine Employees Pension Fund, the Mineworkers Provident Fund, and the Sentinel Retirement Fund.

According to the Chamber workers in the gold and coal mining sectors now have substantial retirement benefits; a medical incapacity benefit and funeral benefits; paid maternity benefits; as well as a framework agreement on women in mining; and a declaration of intent on HIVI AIDS. In addition, the minimum wage has increased substantially: in July 2002 the minimum wage for underground workers in the gold mining industry was R2 000 . By July 2006 this had increased to R2 670. If one factors in the employer's contribution to the provident fund and the living-out allowance (for workers not living in a hostel) the minimum in was R4 069. The minimum surface rate shows a similar increase: in January 2004 it was R2 000 and in July 2006 it stood at R2 427; with the provident fund contribution and living-out allowance added in the minimum rises to $\mathrm{R} 3790 .{ }^{61}$

An important agreement is one that regulates sub-contracting. This agreement holds the main employer (that is, the contractor) responsible for health and safety standards. It also provides that the main employer has to ensure that the sub-contractors are registered in respect of the relevant laws and are making the required contributions, that is, health care, retirement and death benefits.

One issue that appears not to have been successfully dealt with is productivity. Bargaining over productivity incentives has a somewhat chequered history in the mining industry. The first productivity agreement was entered into in 1991 and was described as "pathbreaking". The agreement provided for an average wage increase of six per cent (that is, below the inflation rate) that was linked to an incentive system that had set production targets and a bonus tied to the gold price (with the potential to add up to seven per cent of the basic wage). Twenty-five percent of the bonus would be distributed equally to all workers and the remaining 75 per cent was divided according to job grade. The agreement did not last (Webster, 1999: 13 \& 19-20).

A separate profit-sharing agreement had been entered into by Harmony Gold and NUM. In

60 Note that membership of these funds is wider than the goal and coal sectors.

61 Wage data supplied by Frans Barker of the Chamber of Mines. 
1992 this became the model for the central agreement. NUM favoured profit-sharing over productivity agreements, mainly because such agreements better accommodated marginal mines and there was less likelihood that productivity increases would result in job losses. The framework for profit-sharing was agreed to at the central level, with the details to be negotiated at each mining company. Not all companies agreed, for example, Gold Fields and Anglovaal stayed out of the agreement and instead offered an extra one per cent on the basic wage increase (Webster, 1999: 13-14).

Thereafter, productivity slipped off the bargaining agenda for a number of years, although some issues were negotiated that had a critical impact on productivity. A committee was set up to re-examine job grades, agreement was reached on full-calendar operations, and the two-tier bargaining agreement was finalised (Webster, 1999: 15).

In the 1997 negotiations productivity again featured prominently. An innovative agreement was reached by NUM and the Chamber that provided for a basic wage increase supplemented by a productivity bonus. The overall target was to increase annual gold production by 90 tonnes. This target would be translated at mine-level into the negotiation of "arrangements for improvement in productivity and production necessary to meet gold production targets" (quoted in Webster, 1999: 15). In order to incentivise the negotiation of such agreements at mine-level it was provided that the wage increase was contingent on the conclusion of a productivity agreement. Subsequently many mines negotiated individual productivity agreements, with the exception of most of the marginal mines. The agreements generally included: the introduction of full-calendar operations or extra shifts; broad-banding the job grading system; the establishment of productivity monitoring forums; the identification of production targets (usually measured as square meters blasted per employee on the mine); the linking of incentive payments to targets; and multi-skilling and monitoring of training (Webster, 1999: 15 and 2021).

However, the sharp drop in the gold price made the target of 90 tonnes unfeasible and the productivity agreements were put onto the back-burner. The crisis that hit the industry meant that the focus of bargaining shifted to dealing with the massive retrenchments that had resulted from the falling gold price. A Gold Mining Summit was held and a Gold Crisis Committee was formed to find a way of managing the job losses. Thereafter, the negotiation of a social plan became the priority (Webster, 1999: 16-22).

Productivity bargaining does not appear to have fully recovered from the crisis. Although the 1997 agreement is still in operation, the Chamber holds that it is not really effective. ${ }^{62}$ NUM appears to mistrust productivity agreements, while the Chamber indicates that employers

62 However, the challenges facing productivity initiatives at mine level can be overcome, as Webster shows in his discussion of the progress made at the Elandsrand gold mine (1999: 47-52). 
are also not happy with aspects of the agreements. There is also the issue of the capacity of the parties to conclude relatively sophisticated agreements at mine level.(Webster, 1999: 24) In any event, there does not seem to be any impetus to investigate alternative productivity schemes at the central level. Initiatives by individual employers to introduce different types of schemes, for example, profit-sharing or gain-sharing arrangements, have also not been successful.

\section{What is the Future of the Bargaining Arrangement in the Gold and Coal Sectors?}

At the $2003^{63}$ wage negotiations NUM tabled a proposal that a bargaining council be established for the mining industry. The parties subsequently agreed terms of reference for a joint investigation into "all of the bargaining options" that may be available to them. Two legal experts were appointed, one by the Chamber and one by NUM. The legal experts concluded that the only two feasible options were either the retention or modification of the existing nonstatutory arrangement or the establishment of a bargaining council. According to the joint submissions by the legal experts, as well as interviewees, a bargaining council would have the following advantages:

- Agreements (especially in terms of wages and conditions of employment) could be extended to non-parties. Such uniform conditions could potentially remove undercutting by employers (this would be particularly important in the coal sector). This can also avoid the problem of leapfrog bargaining or pattern bargaining. It would also create more certainty regarding the Chamber's membership because members would not have an incentive to leave simply to avoid a collective agreement.

- The industry currently relies on annual exemptions or variations to the BCEA granted by way of a ministerial determination, particularly in so far as hours of work are concerned. However, a collective agreement concluded under the auspices of a bargaining council might facilitate the implementation of a greater degree of flexibility in employment conditions than is currently the case.

- A single set of negotiations that led to one agreement covering the whole industry would avoid the cost and time of a multiplicity of negotiations at other levels.

63 Appartently NUM have been talking about a bargaining council for about ten years, but it was only in 2003 that the union made a firm proposal in this regard. 
The legal experts stated the following disadvantages of establishing a bargaining council:

- Bargaining councils are generally more costly than non-statutory bargaining structures, and these costs are primarily borne by the parties to the council, usually by a system of levies. A bargaining council also necessitates the funding of a secretariat, an inspectorate and a dispute resolution centre. The latter is particularly worrying for employers. They argue that with a council one is effectively privatising dispute resolution and enforcement that would otherwise have been done by the CCMA and Department of Labour. So there is a likely increase in costs. But the quid pro quo would be if such arrangements had benefits for the parties, for example, a council might provide a more effective dispute resolution system for the mining sector than the CCMA does.

The investigation culminated in a one-day conference in March 2005 at which research was presented and workshops conducted in respect of three key issues that would face a bargaining council: collective bargaining, small miners and contractors, and dispute resolution. At the conclusion of the conference a team of experts was established (comprising employer representatives from the four mining sectors and union representatives) and tasked with developing founding principles for the establishment of a bargaining council. ${ }^{64}$

Progress with establishing the council has been somewhat slow, although it is clear that a lot of work is being done. The Chamber has held meetings with employer representatives of the four mining sectors to develop a common position and with the Department of Labour to get clarity on certain key issues. There have also been further meetings between the Chamber and NUM and the other unions in the sector. In September 2006 the Chamber was tasked with preparing a document that would identify the critical issues around which agreement would need to be reached for the establishment of the council. The Chamber was also asked to prepare a timetable for establishing the council.

The document the Chamber prepared identified the following critical issues:

- $\quad$ The scope of a council;

- Recognition criteria for membership of the council for unions and for employers' organisations;

- $\quad$ Levels of bargaining, and what topics would be negotiated at which level;

- The definitions of small and medium employers, and how their interests would be protected;

64 This section draws on articles in the Labour Policy Digest (March, 2005; July, 2006; November, 2006; and, March, 2007) as well as the Chamber of Mines website. 
- How will contractors be covered;

- The dispute resolution function of the council;

- The appointment of an inspectorate to monitor and enforce compliance by non-parties;

- The extension of council agreements to non-parties

- The exemption body and the procedure for exemptions from council agreements.

It is clear from the nature of the above issues that there is still a lot of work that must be done by the parties. Many of the issues will require difficult negotiation. For example, defining the scope of the council is seen as a potential problem. What will the boundaries of the industry be, who will be in and who will be out, and how far up or down the pipeline does one go? In particular, will a bargaining council include the diamond and platinum sectors? While it is probable that employers in the gold and coal sectors will not have major objections to the proposed council, it is likely that employers in the diamond and platinum sector, who are used to bargaining at company level, will be less enthusiastic about the prospect. Another challenge is posed by the sub-contractors in the industry. Does one include them within the scope of the council? If so, would this be in a separate chamber? This is a major concern of NUM and provides a strong motivation for a council, that is, it sees a council as one of the best ways of regulating outsourcing and sub-contracting, particularly the so-called 'general mining contractors' (rather than the specialist contractors).

At the time of writing the parties were starting discussions. In February 2007 the unions submitted their response to the Chamber's position on the above issues, and the parties met in early March to get down to hard bargaining. The stakes are high. A council for the mining sector would be a huge boost for the bargaining council system as a whole. Even if the council were just to cover the gold and coal sectors this would add about 250000 employees to the total covered by bargaining councils. In the meantime centralised bargaining continues in the gold and coal mining sectors - two-year agreements for each sector were negotiated in 2005 - and decentralised bargaining takes place for non-Chamber members in these sectors as well as in the diamond and platinum sectors.

Frans Barker believes that a bargaining council is a distinct possibility for the gold and coal sectors, but not in the other sectors within the industry. The Chamber believes that what NUM want is an overarching structure with the four main sectors, that is, gold, coal, diamonds and platinum group metals, accommodated in four chambers. However, the Chamber would have to sell this to members in order to get a mandate. Then they would be prepared to engage on a bargaining council, based on a clear set of principles. A concern for employers is to minimise bureaucracy and to keep costs low. This they see as one of the major disadvantages of the proposed council. There is also a concern over two-tier bargaining arising with the advent of the council. Furthermore, for firms that are not covered by existing bargaining but which would 
be covered by an extended agreement, the bargaining council is a huge threat. Barker argues "you can't produce gold in those shafts paying Anglo wage rates".

Whether in a bargaining council or the current arrangement, the Chamber would like to see improvements in the process of getting to agreements. The Chamber believes that negotiations could be more efficient if they were preceded by some sort of process that would identify common ground and narrow issues of difference (for example, workshops combined with small working groups to tackle particular issues). The Chamber has previously got outside facilitators involved but this never really took hold. On the other hand, the current two-year agreement has proved to be very efficient. It frees up people to do other things in the year when negotiations do not take place.

\section{Automobile Manufacturing}

In the 1980s labour relations in the automobile industry were turbulent as a number of new unions challenged management and fought each other for members. This situation started to stabilise somewhat when in 1987 unions came together to form the National Union of Metal Workers of South Africa (NUMSA). ${ }^{65}$ With worker organisation consolidated and the union and employers reaching more sophisticated agreements, labour relations entered a new phase. A key aspect of this new phase was the push by NUMSA for a centralised bargaining forum for the industry. The new phase of struggle was, therefore, "less about the legitimacy of who could play and who would be in the teams, more about structuring the game" (Anstey, 2006: 14).

At that point various collective bargaining arrangements existed in the industry. Ford, VWSA and General Motors were represented in a regional industrial council by the Eastern Province Automobile Manufacturers Association (EPAMA), whereas Toyota, BMW and Nissan negotiated at enterprise level. The South African Motor Corporation (Samcor) participated in the industrial council for its Port Elizabeth factory but bargained at plant level at its Pretoria operation. Mercedes-Benz South Africa (MBSA) joined the industrial council in 1986 but left in 1987. In 1989 NUMSA sought to rationalise the bargaining system when it issued a demand to the Automobile Manufacturers Employers' Organisation (AMEO) to form a national centralised bargaining forum for the industry. AMEO rejected the demand, a move that was supported by the Eastern Province Automobile Manufacturers Association (EPAMA), although the latter indicated it would continue to bargain in the regional industrial council. MBSA stated that it would bargain at any level provided it did not have to bargaining at two levels (Anstey, 2006: 15).

In the months that followed NUMSA met with employers and co-ordinated protest action at automobile plants. In 1990, after a lot of tactical manoeuvring, negotiations, protest action and 
a court case, the National Bargaining Forum (NBF) was established. It was initially not very stable. Delta, Toyota and Nissan were reluctant participants and NUMSA battled to convince its members at Mercedes Benz (which had the highest wage rates) to abandon plant level bargaining in favour of the negotiations at the new forum. Not surprisingly, in its first few years the NBF was shaky: each year negotiations had to go to mediation and each time NUMSA took workers out on strike. Despite this instability the parties began to fashion some sophisticated collective agreements with joint commitments to the "long-term growth and viability of the industry and the protection of jobs within it; a jointly controlled Industry Education and Training Board, funded by employers; multi-skilling, career pathing, 'portable' skills development and training relevant to the changing economy; adult literacy; affirmative action; a Work Security Fund funded by employers...; an industry retirement scheme; a medical fund; [and to] eliminate 'apartheid wage discrepancies'” (Anstey, 2006: 15-16).

The political transition to democracy brought new challenges to the automobile industry. The response of the industry saw a deepening of the relationship between unions and employers. A task group was formed (the Motor Industry Task Group), comprising management and the union, that did a study trip to a number of countries to get knowledge of global competitive conditions and strategies. It appears to have been a sobering experience and resulted in a number of recommendations that would need to be implemented urgently to make the industry internationally competitive. But the recognition of serious threats to the industry did not stop the adversarialism in the relationship. In the same year NUMSA embarked on a four-week strike over wages and a demand to close the 'apartheid wage gap'. As the strike dragged on government announced a 35 per cent reduction in tariffs for the industry, with a commitment to further reductions. The strike was soon settled but the costs to both sides were high (Anstey, 2006: 16-17).

In 1995 the NBF reached its first three-year agreement. It was designed to put an end to the 'apartheid wage gap'. In many respects it was a groundbreaking agreement. Anstey provides a summary of its main features:

The agreement discontinued merit and service increases, regulated pay for skills via training and recognition of prior learning, set wage differentials at $10 \%$ (grades $1-5$ ) and $20 \%$ (grades $5-7$ ), and reduced wage spreads through fixed minima and maxima. Wage increases over the three-year period were regulated through cost of living indexed increases (COLA). The parties made a joint commitment to improve operating efficiency, productivity, skills and quality of working life, regular meetings and disclosure of information, while acknowledging the multi-factor nature of productivity and a joint responsibility to improve in this area. Beyond this they agreed to reschedule and recover lost production through strike 
action, to reduce absenteeism, inventory and waste and to raise quality and develop people. Wages were indexed to inflation, with provisions for reopening negotiations should inflation rise above $14 \%$ or fall below $7 \%$ (2006: 18).

The wage negotiations in 1994, 1995, 1998 and 2001 all resulted in strike action. This was avoided in 2004, but only because of the involvement of an independent mediator from the outset. It nevertheless took four months of negotiations to reach agreement (Anstey, 2006: 18).

The sophisticated agreements being reached by the NBF were matched by new initiatives and agreements at the enterprise and plant level to build better relationships and produce better performance. At Nissan a relationship building exercise in 1994 led to improved relations and production. This was followed in 2001 by agreement to introduce a staggered shift system to benefit production and in 2002 by an agreement to change the demographic profile of the company. The company then engaged in an exercise to replace 520 long-serving employees with 520 new recruits who would receive intensive training. Employment equity considerations were a key factor in the appointment of the new employees (Anstey, 2006: 21).

At Mercedes Benz SA the Siyapambili Agreement ('Moving forward together') was signed with the union in 1996. It represented a commitment to adopt a new approach to work in the face of global competition. Flowing from this was a "massive expedited training initiative" with assistance from Germany "to facilitate upgrading and expansion of the plant", and a "monthly performance-based reward system replaced a previous ad hoc bonus arrangement".(Anstey, 2006: 21) This resulted in the creation of 300 new jobs and a big increase in productivity. In 2001 a new Siyapambili Agreement was signed that re-committed the parties "to achieve the company's vision and values and build a world class organisation through continuous improvement".(Anstey, 2006: 21) Communication, participation and shop steward capacity were the main focus areas.

A similar process emerged at Toyota. In 2000 the company entered the Masibambane Pact with NUMSA which recognised the partnership between the company and employees in meeting competitive challenges. The Pact committed the parties:

...to the "Toyota Way" in which they recognised obtaining and retaining exporter status, cost down activity, labour stability and improved overall quality as key strategic imperatives and jointly committed to a relationship of open and honest communication, trust and mutual respect, timeous information sharing, respect for one another's rights and obligations and the embodiment of shared values of openness and integrity (Anstey, 2006: 21). 
Structures and interaction were clarified at the various levels of engagement from the NBF down to plant-level, and the Pact also defined the roles and responsibilities of management and shop stewards. The Pact endorsed flexibility in shift and work planning, the need for periodic overtime, and changes to the system of shutdowns to limit disruption. Training and development as well as job security were dealt with in the Pact. A comprehensive incentive scheme was introduced (the Toyota South Africa Motors (TSAM) incentive scheme) and it was agreed that disputes relating to the Pact would be dealt with through arbitration (this amounted to a no-strike clause) (Anstey, 2006: 22).

The Pact was built on in 2005 by the Riverside Declaration "in which the parties committed to trust and respect as cornerstones of their relationship and to continuous improvement to ensure that the company remained the number one automobile company in the country and a World Class competitor" (Anstey, 2006: 22). The Declaration also committed the parties to respecting each other's rights and obligations as well as to the collective agreements in place. In addition, the parties "further committed to respecting the rights and dignity of all employees, developing the human resources of the company, ensuring a safe and healthy workplace, respecting the environment, to good governance and corporate citizenship and to job creation, job security and labour stability" (Anstey, 2006: 22).

At BMW a Performance and Delivery Agreement was entered into with NUMSA in 2001, which committed the parties to making BMW competitive in comparison to other BMW plants on the elements of cost, quality and volumes. Systems were agreed to enable flexible shifts and to maximise use of plant, and a working time account system was added that introduced flexibility into production time (Anstey, 2006: 22).

The process was followed later at Ford. In 2005 the Yeyethu Sonke Agreement ('It belongs to all of us') was entered into by the company and NUMSA at its engine plant in Struandale. The Agreement covered the mission, vision and business objectives of the plant and also introduced:

...a set of key joint commitments, inter alia to building a relationship of trust and transparency, fostering a diverse and capable workforce at all levels, building a new work organisation based on autonomous and empowered teams, legal and procedural compliance and a zero quality defect mindset, and to improving health and safety in the workplace and to the workplace environment (Anstey, 2006: 22).

The Agreement went on to deal with standards of conduct in meetings, hearings and disputes, the roles of management, human resources and shop stewards, and introduced a system of participatory structures that would deal with a number of key issues (Anstey, 2006: 22). 
VWSA was ahead of all the others regarding such agreements, but it was at VWSA that one saw the dangers these agreements faced in the context of a legacy of adversarialism. In 1994 a plant agreement was negotiated at VWSA that committed the parties to:

- an increase in production to 100000 units a year depending on demand

- $\quad$ efficiency and competitiveness

- $\quad$ cost reduction and quality improvement to offer the market more affordable and high quality vehicles

- $\quad$ organisational and employee flexibility

- $\quad$ ongoing education, training and development of employees

- $\quad$ employment protection within the bounds of the agreement

- the promotion of employee participation through codetermination practices (Anstey, 2006: 23)

The agreement covered a number of other key issues: flexible manufacturing; outsourcing; new participatory structures; employment security (guaranteed for a year for most workers); an employee development scheme; a new system of work organisation; multi-skilling training; leadership development; affirmative action; and a performance-based reward system.

Provision was also made for "a multi-tiered joint union-management structure consolidating and supplementing existing structures in the company" (Anstey, 2006: 23).

A few years later VWSA was given an export contract by VWAG that would require the company to almost double production. This would necessitate further restructuring and changes to be agreed with the union, but it had one major benefit: about 850 new jobs would be created. With this in mind, NUMSA agreed to commit to quality, production and cost targets; a continuous shift system; holiday corridors; labour flexibility, stability and attendance; a teamwork system; and reduced tea breaks (Anstey, 2006: 23).

The agreement caused tensions to rise within the unions and by 2000 a split emerged when about 1500 workers went on strike over a demand that NUMSA revoke the suspension of a group of shop stewards that had opposed the agreement. It was a strike that attracted a great deal of attention and was well-publicised. It eventually resulted in the dismissal of 1336 strikers and a protracted legal fight for their reinstatement that went to the CCMA, the Labour Court and the Labour Appeal Court. But, as Anstey notes, the issue was not the legal battle but rather "the sharp shift in power relativities the situation revealed" (2006: 24). Global competition had changed the nature of industrial relations in the sector. 


\section{The Current Situation Regarding the NBF}

There are currently two parties to the NBF, AMEO (the Automobile Manufacturers Employers' Organisation) comprising the seven OEMs (Original Equipment Manufacturers) in the country (that is, Toyota, VWSA, General Motors, Nissan, BMW, Ford and Daimler Chrysler), and NUMSA. ${ }^{66}$ This means that all the employers in the sector are represented on the NBF and agreements emanating from the NBF will bind the whole sector. It covers 26000 to 36000 employees. ${ }^{67}$ NUMSA represents about 25000 employees.

The NBF is purely a collective bargaining forum and is a lean operation. It does not have a constitution, is not registered in any way, and it has few rules and formalities. Furthermore, participation is voluntary. It was formed through the power of NUMSA and that is how the bargaining forum is maintained at the centralised level. It has plenary meetings once a quarter and has a Management Committee which deals with the budget and oversees the administrative activities of the Forum. It employs only one person (an administrative secretary) and has an office in Pretoria with a number of meeting rooms. Expenses are covered by eight equal contributions from the parties (that is, the seven OEMs and NUMSA).

As indicated above, the NBF has for some time been producing three-year agreements; it now has a single agreement covering all issues. The focus of the agreement is wages and conditions of employment but it covers a range of other issues. The parties identify a number of key features of the agreement. First, according to NUMSA, the NBF has been used to bring the wages of the lower grades up to "acceptable" levels, that is, not as high as the union would like but at least "acceptable". Second, and this is a feature highlighted by both the employer and the union interviewees, is provision for payment for skills acquired (rather than skills used). This is encapsulated in a complex training and wage system in the agreement. The training is now done under the auspices of the Manufacturing, Engineering and Related Services Sector Education and Training Authority (MERSETA) but the recognition in terms of wage levels is in terms of the NBF agreement. What this means is that workers can move up to grade four (of the seven grades for weekly-paid workers), and be paid at the grade four rate, by acquiring additional skills even though they remain in the same job. ${ }^{68}$

Third, the agreement establishes a Work Security Fund - it currently has funds of R60 million - that is designed to provide training in order to re-skill employees who lose their jobs as a result of a major retrenchment. Fourth, the NBF has a dispute resolution function dealing with the interpretation and application of the agreement. Rights disputes go through arbitration and

66 UASA was a member of the forum until 2003 but now has very low membership in the sector.

67 All hourly paid workers in the industry are covered. The employer interviewee estimated that there were 26 000- 28000 such employees and the union interviewee estimated 36000 employees.

68 Grade five is the artisan level and so forms something of a ceiling for the system 
interest disputes will go to mediation/conciliation and then, if not resolved, to industrial action. Disputes that arise at the plant level and relate purely to the plant do not go to the NBF. They will be dealt with at the plant-level and then go to the CCMA.

Fifth, the agreement effectively prohibits dual-level bargaining, but does provide for the negotiation of incentive schemes at plant-level, gives guidance as to how such negotiations should take place, and also provides for the negotiation of a range of variations within parameters set by the NBF agreement. As indicated in the company- level initiatives outlined above, the need to raise productivity and quality levels are seen as critical for the industry's competitiveness. So, the incentive schemes are a very important tool for employers to achieve improvements in this regard.

The NBF agreement makes provision for the establishment of pension/provident funds and medical aid funds, but this provision has never been activated. All these funds are already in place at the individual companies.

Another feature of the NBF has been with regard to skills development. This has been alluded to above with regard to the link with the grading system and wage levels. However, it was also identified as an achievement in its own right. It was emphasised that although skills development now falls under the MERSETA, the system was in place prior to the MERSETA and the major achievements were driven by the NBF. If anything, there was a sense that having to integrate into the SETA has slowed things down for the industry. Furthermore, employers argue that the union is using the MERSETA as a second bargaining opportunity for any issues relating to training that arise at the NBF, that is, if the union cannot get what it wants at the NBF then it tries again at the MERSETA.

\section{What is the Future of the NBF?}

It is recognised by both employers and NUMSA that the NBF has some significant achievements and has brought considerable stability to the industry, as well as greater predictability for employers. This suggests that the NBF will remain stable into the future, continuing to produce what are generally seen as very sophisticated, cutting-edge agreements. ${ }^{69}$ But there are some potential threats to its stability. An exogenous factor that could destabilise the NBF is the state of the industry, in particular what happens to the Motor Industry Development Programme (MIDP) in future. The latter has underpinned the good export performance that has been achieved.

$69 \quad$ According to an interviewee the NBF agreement has been used by the Minister of Labour and Governor of the Reserve Bank to impress the International Monetary Fund and World Bank with regard to the sophistication of industrial relations in the country. 
The interests of the parties are also potential threats to the NBF. It is ironic that while praising the NBF both employers and the union appear to want to move away from it in different directions. On the one hand, the union have in mind the creation of a mega bargaining council. This will incorporate the metal and engineering sector (and its bargaining council), the tyre sector (and its bargaining council), the motor sector (and its bargaining council), and the automobile sector (and the NBF). Each sector would be accommodated in a chamber within the mega council. It is an ambitious long-term project and would mean the end of the NBF as it is now. It seems that employers would strongly resist such a move.

Even if NUMSA is not able to achieve the above, it is apparent that it would still like to establish a bargaining council for the automobile manufacturing sector. The main reason is the desire to pull the automobile components sector into the same forum as the manufacturers (automobile components firms are currently split between the metal and engineering bargaining council and the motor industry bargaining council according to the nature of the firms). If this were to take place there would be a need to extend the collective agreements reached because of the number of components firms, which would necessitate the establishment of a bargaining council. This would also be an ambitious project. It is certain that the metal and engineering bargaining council and the motor industry bargaining council would resist losing components firms. It also appears that there is some resistance within NUMSA to the components firms going into the automobile manufacturing sector.

On the other hand, the employer interviewee indicated a preference for greater decentralisation of bargaining, at least in the long-term. But he also acknowledged that there was very little likelihood of this happening given NUMSA's power and the sort of pressure the union would bring to bear on employers. But it was clear that employers were definitely not in favour of greater centralisation. For example, there is dissatisfaction with the way that the NBF has distanced negotiations (and therefore rewards) from the shopfloor and the performance of individual firms.

Whether any of the above intentions will be realised remains to be seen. There are high risks for both parties in destabilising the NBF when it has delivered so much. It might well be that the parties remain engaged in the NBF. For example, while indicating a preference for decentralised bargaining, an employer argued that it is now the time to take the NBF even further. He believed that it should deal with a new set of issues, such as employee share ownership schemes. The latter suggests a long-term commitment to the NBF.

\section{Pelagic Fishing}

The centralised bargaining forum for the pelagic fishing sector is at least thirty years old and appears to have changed very little over the years, although there have been changes to the parties along the way. The emergence of FAWU changed the union party on the council. On the employer side there have also been changes, with the restructuring of the South African 
Inshore Fishing Association. Previously this was an association that attended to collective bargaining and other matters as well as doing the marketing of fish meal and fish oil for the industry. A few years ago this became a private company, which now provides secretariat services for the South African Pelagic Fish Processors Association and other fishing industry associations. ${ }^{70}$ These services include collective bargaining but also cover other association functions. ${ }^{71}$

The above changes do not appear to have threatened the centralised bargaining arrangement, although it might have had some influence because there now seems to be a greater willingness on the part of employers to break ranks if a firm is facing a difficult year. However, this tends to be a temporary thing and firms generally re-join once they are more profitable again (see further below).

The sole employer representative is the SA Pelagic Fish Processors Association. It is not registered as an employers' organisation although there has been quite a lot of discussion about it registering. The member firms of the Association are as follows: St Helena Bay Fishing Company (Oceania Group); Lamberts Bay Canning Company (Oceania Group); SA Sea Products (Oceania Group); Westpoint Fishing Company (Saldanha Group); North Bay Canning Company (Oceania Group); Oranjevis Ltd.; Gansbaai Marine Ltd.; and, Premier Fishing SA (Pty) Ltd. There are a number of 'small players' in the industry that are not part of the forum.

The only major pelagic processor that is not part of the forum is Marine Products. The firm was a member of the forum but recently left, giving the reason that it prefers to bargain with FAWU at plant-level. However, it appears that bargaining does not actually take place at Marine Products. What happens is that FAWU simply compel Marine Products to comply with the centralised agreement. The real reason for the firm's withdrawal is probably that it thought it could exploit the fact that FAWU lost its majority at the firm.

The centralised bargaining forum should include only pelagic fishers but its scope is somewhat flexible. Bargaining used to include a number of lobster fisheries but now only North Bay Canning is left. It also seems that Lamberts Bay Canning has a vegetable processing operation that falls under the agreement.

The bargaining unit covers about 5000 weekly-paid workers. FAWU is the only union and represents about 70 per cent of the workers covered.

70 There is a processors association and an association of all rights (quota) holders.

71 South African Inshore Fishing does the marketing of fish meal and fish oil for the individual companies, that is, not the industry as a whole as in the past. 
Forum exists only for collective bargaining. It is activated to bargain once a year over wages and conditions of employment, and deals with other issues during the year as and when they arise. Whatever is dealt with in the agreement cannot be negotiated at firm level. However, the scope of the agreement is quite narrow. Most of the firms have negotiated social security benefits such as provident fund, medical aid and housing schemes at the firm-level. Any additional issues will generally be bargained at firm-level. However, it might be that an issue is raised at plant level which is then referred to the forum for consideration. A framework for productivity bonuses is in the centralised agreement but the details are negotiated at the plant level to take into account differences between plants.

It was noted above that if a firm is not able to pay the wage increase that is being offered it can step outside the forum. It will then negotiate with FAWU at plant-level. This might take place for one or two years, but generally once the firm is over its problem it will come back into the forum.

The forum has no staff. The cost of the negotiations is borne by the employers, and the employers' association makes all the arrangements for the negotiations (that is, books the venue and accommodation, organises transport, etc.). The total cost is then split amongst the employers. The secretariat services to the Association are provided by SA Inshore Fishing and are covered by the members' subscriptions.

\section{What is the future of the Pelagic Fishing forum?}

FAWU has been pushing for about a decade for the establishment of a bargaining council in the fishing sector. In 2001 the union declared a dispute at the CCMA with respect to this demand. A meeting was held in that year and employers (that is, from all branches of the industry, not just the pelagic sector) agreed in principle to pursue setting up a bargaining council. A few meetings followed but no real progress was made.

Subsequent to the above process, a bargaining council was established for the fishing industry but it has a narrow scope, covering only sea-going employees in the hake sector. FAWU has recently got onto the council and it seems that the union's strategy is now to expand the scope of this council and pull the pelagic sector into it, where it will be accommodated in a separate chamber. However, employers in the pelagic sector do not see the point of going into a bargaining council. As far as they are concerned the existing centralised bargaining forum is working very well and there is no need to change. A bargaining council would not have any benefits for them. In theory the main advantage of a council would be to extend the agreement to the small firms in the sector. But these firms are not a competitive threat to the big firms and make up only about 10 per cent of the sector. So the major employers see no need to extend the agreement. In any case, it appears that many of the small firms actually adopt the forum's agreement, either voluntarily or at the insistence of FAWU. On the other hand, employers argue that a bargaining council will probably lead to more cost for employers. 
This does not appear to be a knee-jerk reaction. Over the last ten years the employers in the sector have given this issue quite a bit of attention, discussing the pros and cons amongst themselves, and obtaining outside advice about their options. At one point some employers were in favour of a bargaining council, but they wanted their own pelagic fishing sector council. Now it seems most do not like the idea.

Another problem facing the union appears to be the existing bargaining council. A spokesperson for the pelagic sector notes that the employers in the bargaining council do not want the pelagic sector to come into it. For its part, the union believe that the bargaining council is little more than an I\&J puppet. The priority for the union is, therefore, to sort out the structure and functioning of the bargaining council. Only then will it deal with the process to incorporate the pelagic sector.

\subsubsection{Non-statutory de-centralised (single-employer) bargaining}

\section{Retail}

There has never been centralised multi-employer bargaining in the retail sector. ${ }^{72}$ Historically bargaining has been with individual firms, with the remainder covered by a wage determination. This is still the case, with unions bargaining at either the national company-level or regional level or store level, and the remaining firms being bound only by a sectoral determination (Sectoral Determination No. 9: Wholesale and Retail Sector, South Africa).

Collective bargaining currently covers only a small proportion of the sector. SACCAWU, the major union in the sector, estimates that its collective agreements cover about 150000 employees. There are a handful of much smaller unions but it is unlikely that they add a significant number to the SACCAWU estimate. The latest Labour Force Survey (March 2006) provides a figure of 2996000 million employees in the sector (including 1041000 informal employees), which means that collective bargaining covers only about 5 per cent of the sector (or about 8 per cent of formal employment). This is lower than most of the employers in the sector estimated: they provided a very rough estimate of about 15 per cent of all employees being covered by collective bargaining.

The reasons for the low level of unionisation are simple. It is a very difficult sector in which to organise: there is a very large number of small and very small retail firms scattered across the country, and there are also very large numbers of informal retail operations. Both categories (which overlap) are almost impossible to organise. Where larger companies exist they are generally national, which means that employees are spread in small pockets across the country. In some cases, particularly in the clothing retail sector, these pockets of employees

72 Other than a tiny bargaining council that covers Kimberley. 
comprise only four or five employees per store. Given the way that the LRA defines a workplace, organising and getting recognition in the sector is immensely difficult. This makes the possibility of centralised multi-employer bargaining remote.

SACCAWU divides the firms it negotiates with into three categories: national groups, medium-sized firms, and small firms. It is currently bargaining at thirty-two national groups, at approximately 250 medium-sized firms, and at 150 small firms (the latter can fluctuate a lot from year to year). ${ }^{73}$ The national groups are the most important sites for collective bargaining and include the major food, clothing and furniture retail chains; for example, Pick $n$ Pay, Shoprite Checkers, Spar Warehouses, Mass Discounters, Clicks (and Discom), Truworths, Foschini, and JD Group.

All of the latter firms were interviewed with regard to collective bargaining arrangements, as well as Woolworths (at which SACCAWU is recognised only in the distribution centre). ${ }^{74}$ Taken together their bargaining units comprise about 117500 employees. So, the interviews provided a perspective on the collective agreements and arrangements of a very large proportion of all workers that SACCAWU estimates are covered by its collective bargaining in the sector.

SACCAWU is recognised at all the above firms (other than Woolworths). There are no other unions recognised for bargaining at the firms: a number of tiny unions still have recognition but this is more an historical anomaly than anything else (that is, they were recognised in the past and remain recognised but have so few members that they barely exist as a presence at the firms). The only new development at the firms is the emergence of the Joint Affirmative Management Forum (JAMAFO) at Pick $n$ Pay. This union organises only at Pick $n$ Pay and comprises only the junior management stratum at the firm. The union is currently recognised for meetings and consultation but not for the purpose of negotiating for its members (it represents about 44 per cent of the 4000 junior management staff).

SACCAWU has been recognised for a considerable period at all the firms. It was recognised at Pick n Pay and Shoprite Checkers ${ }^{75}$ in the early 1980s; at Foschini in the mid-1980s; at Spar, Clicks (and Discom), Mass Discounters and Truworths in the early 1990s; and at the JD Group in the late 1990s. This probably represents the wider pattern of organisation for the union,

$73 \quad$ Note that SACCAWU has included firms in the hospitality sector in the numbers for the three categories. Such firms generally make up a small proportion of the categories.

74 We would like to thank Tanya Cohen of Woolworths for providing us with an introduction to these firms, all of which are members of the Retailers Association.

75 There is currently no recognition agreement at Shoprite Checkers (it was unilaterally cancelled by management in 1992). In practice, however, SACCAWU is recognised for bargaining. The union has for some time been pushing for a new recognition agreement but management have resisted, arguing that it is not necessary. 
as it radiated out to the clothing and furniture retailers from its stronghold in the two big food retailers (that is, Pick n Pay and Shoprite Checkers).

There is substantial commonality in terms of bargaining units but there are also some important differences. Almost all the above firms bargain at the national level for the entire group. The exception is Spar, which has a business model that treats its six regional distribution centres as entirely different entities. Negotiations, therefore, take place separately at the distribution centres: currently only four are unionised and are therefore involved in negotiations. Furthermore, each Spar store is individually owned (it is termed the 'voluntary trading' business model). So collective bargaining is decentralised to each individual store and is entirely the responsibility of the store- owner. There is no co-ordination or monitoring of collective bargaining by Spar centrally. It is therefore not known how stores have recognised or bargain with unions.

Most of the other retail firms also exclude what they see as independent operations and franchise stores. For example, Pick $n$ Pay does not bargain for Boxer and Score because these are seen as independent. It also does not bargain for the approximately 150 Pick ' $n$ Pay Family Stores that are franchises. Similarly, the Clicks Group has separate bargaining units for Clicks and Discom, and does not bargain for Musica and The Body Shop. Shoprite Checkers differs slightly. Its bargaining unit covers a number of separate operations: Shoprite and Checkers stores; Checkers Hyper; House and Home; OK Furniture; U Save; and the Hungry Lion. However, the bargaining unit does not cover the franchises: OK Foods and OK Grocer.

Subject to the above exclusions, the retail firms are strongly in favour of bargaining nationally. For most it has never been an issue and there is no desire for more decentralised bargaining. In fact, almost all the retailers do not provide any scope for regional or store-level bargaining in their recognition agreements with the union. ${ }^{76}$ The reasons vary. National bargaining suits Shoprite Checkers because it has a highly centralised business model. The JD Group have a centralised pay-roll so it would not be feasible to bargain regionally or at the store-level. Pick $n$ Pay wants to have a single national rate for jobs, partly because this facilitates mobility between stores.

The use of casuals has always been a feature of the retail sector and has posed a major organisational challenge for SACCAWU. Over the last decade or so retail firms have employed more and more people on a casual basis. ${ }^{77}$ Since the introduction of Sectoral Determination No. 9 most of these employees are categorised as flexi-timers and are covered by the provisions in the Determination (some retail firms still have an additional category of 'casuals').

76 In the retail sector recognition agreements are generally referred to as relationship agreements.

77 SACCAWU estimates that there are about half a million full-time workers in the sector and the rest are casual or flexi-timers (that is, this would be over 2 million workers according to LFS data). 
However, some retail firms include the flexi-timers in the bargaining unit, while others have resisted their inclusion. Pick $n$ Pay includes permanent and flexi-timers in its bargaining unit: there are about 14000 permanent employees and about 14000 flexi-timers in the unit, with SACCAWU representative of about 75 per cent of the total. Shoprite Checkers only included flexi-timers in the bargaining unit after the Determination was introduced. This swelled the size of the bargaining unit from 20000 to 55000 employees (there are 35000 flexi-timers), and in the process SACCAWU's representivity dropped from 60 per cent to below 50 per cent. The Foschini Group also include flexi-timers in the bargaining unit: about 30 per cent of the 12000 employees in the unit are flexi-timers. But union representivity at the Group is very low: it is estimated at about 16 per cent. ${ }^{78}$

The Clicks Group, Discom, Mass Discounters and Truworths do not include flexi-timers in the bargaining unit. At Clicks the bargaining unit covers about 3000 permanent employees (about 60 per cent are SACCWU members) but excludes 2500 flexi-timers. Similarly, the bargaining unit for Discom covers about 1000 employers (64 per cent are SACCAWU members) but excludes 400 flexi-timers. Apparently SACCAWU have pushed for the flexi-timers to be included but the company has resisted, arguing that including them would make SACCAWU unrepresentative. However, recently the company offered to make the flexi-timers permanent, which would see them included in the bargaining unit. The quid pro quo was greater flexibility with regard to working hours. At the time of the research the union had not, according to the firm, responded to this offer.

The number of flexi-timers and casual workers in the sector and the recent trend to franchise stores pose major problems for union organisation. Flexi-timers are difficult to organise but there is also opposition to them being organised from full-time workers because they put downward pressure on the job security and conditions of employment of the latter employees. The union took a decision at its 2004 Collective Bargaining Conference to include flexi-timers and casuals in all its bargaining units and to ensure that such workers have access to the same benefits that full-time employees receive. Its aim is obviously to forge unity between the two categories of employee. However, as we have seen above, the union has not succeeded in achieving this goal at all the major retailers. A new strategy that the union is considering is to demand that flexi-time workers get a premium wage, that is, flexi-timers get paid a higher wage rate for working such hours. ${ }^{79}$ This would probably slow the trend to casualisation. A problem

78 The union states that it has also managed to include flexi-timers in the bargaining units at Edgars and Ellerines.

79 It should be noted that Sectoral Determination No. 9 provides that flexi-timers (that is, employees who work 27 hours or less per week) may in terms of a written agreement (which includes a collective agreement) receive a wage premium of 25 per cent their hourly rate. However, such an agreement excludes an allowance for night work, sick leave and family responsibility leave, and reduces paid annual leave to two weeks (clause 11). Presumably the union is aiming to gain the wage premium without making the latter concessions. 
with this strategy is that it might emphasise the differences between flexi-timers and full-time employees.

Many retailers, on the other hand, believe that the sectoral determination has largely resolved the problem of casualisation by regulating it. The key division in the determination is between employees who work more than 27 hours per week and those that work 27 or less hours per week. ${ }^{80}$ With regard to the latter, two alternative regimes are proposed. On the one hand, a written agreement (which includes a collective agreement) can be entered into that provides the employee with a wage premium of 25 per cent of the relevant hourly rate and two days off per week, but which drops the employee's right to a night work allowance, sick leave and family responsibility leave, and reduces paid annual leave to two weeks. On the other hand, if no agreement is entered into the employee who works 27 hours or less per week gets the hourly rate and all basic conditions in the determination apply, where relevant on a proportionate basis.

Retailers argue that the determination clarifies the position of flexi-timers and leaves them no worse off than full-time employees. This has regulated and stabilised the situation of flexitimers. It also seems that the introduction of the sectoral determination has influenced some retailers to include flexi-timers into their bargaining units. But there are still major retailers that have kept flexi-timers out of the bargaining unit. In some cases retailers are offering the inclusion of flexi-timers into the bargaining unit in return for greater flexibility in the arrangement of hours of work. This was the case at Shoprite Checkers some years back, when it was agreed to bring flexi-timers into the bargaining unit and guarantee them a minimum of 80 hours work per month, in return for paying Sunday work at standard rates. Much the same trade-off is being proposed at Clicks, where management has offered to include flexi-timers in the bargaining unit in return for greater flexibility regarding working hours and the arrangement of working time.

Another trade-off that appears to be happening in the sector is with regard to the period of collective agreements. SACCAWU has adopted a strategy of signing one-year agreements unless they get certain concessions. It does not seem coincidental that the retailers that have got two or three year agreements are those that have included flexi-timers in the bargaining unit (for example, Pick n Pay and Shoprite Checkers) and retailers that have not are stuck with one-year agreements (for example, Mass Discounters and the Clicks Group). However, SACCAWU do not seem to have made this trade-off explicit because there is considerable dissatisfaction on the part of some retailers at what they perceive as the union's inconsistency.

$80 \quad$ Special provisions in the Determination apply to employees working 24 hours or less per month and those working 40 hours or less per week, including Sunday. In practice these thresholds do not appear to be as important as that set at 27 hours per week. 
Casualisation is the dominant process in the retail sector through which workers are shifting from standard to non-standard forms of employment. However, externalisation is also evident in the sector. We have seen above that franchising is a growing trend in the sector and poses threats for union organisation and collective bargaining. The outsourcing of the merchandising function is a further example of externalisation. Most major retailers now have distributions centres. Goods are delivered in bulk to the distribution centres by suppliers (rather than to individual stores). The retailer then distributes supplies in smaller quantities to its stores. Merchandising is the process of packing goods from the storeroom at the individual retail outlets onto the shelves. Increasingly this function is being performed by specialised merchandisers. The benefit for the retailer is that they not longer employ shelf packers and hire the merchandiser to do this work as needed. For example, a store might contract for the merchandiser to come in for two hours each morning to pack shelves before the store opens. Thereafter those workers might move on to another store for a certain period.

Organising workers at merchandisers is clearly going to be difficult for a union. They are employed primarily at the workplace of a client and are seldom in one place for very long. However, SACCAWU state that they are bargaining with the major merchandisers in the industry, that is, Smollens (a merchandiser that deals with a number of the major retailers) and Daymons (which seems to work exclusively for Pick $n$ Pay). ${ }^{81}$ The scope of Sectoral Determination No. 9 also includes merchandising.

Another example of externalisation is the use of labour brokers. It seems that this is limited in the retail sector and is directed mainly at the distribution centres. For example, one of Spar's distribution centres uses two labour brokers to "manage the peaks and slumps". Distribution centres are generally strongholds of union organisation because they comprise large concentrations of workers. But they are also strategic targets (that is, a strike at a distribution centre will have a huge impact on a large number of stores within a fairly short space of time). It is unclear whether the use of labour brokers is also intended to undermine union organisation and make retailers less vulnerable to strike action at distribution centres.

The retailers generally place no limits on the bargaining agenda. But it appears that it is relatively easy for management to push issues they do not want to negotiate onto a secondary agenda and then to roll these over from year to year. It is therefore not surprising that the topics of bargaining in the retail sector appear to be fairly standard at most retailers, although at the bigger general retailers like Pick $n$ Pay a wider range of issues is covered. ${ }^{82}$ In the case of Pick $n$ Pay this is probably because of a desire to go beyond the conventional bargaining relationship and develop something closer to a strategic partnership.

81 However, this was denied for a representative of Smollens, who stated that SACCAWU had very few members at the firm and was not recognised.

82 In numerous separate collective agreements. 
A further example of this is the on-going formal interaction between management and the SACCAWU at Pick ' $n$ Pay. Between meetings of the firm's National Negotiating Committee (NNC) a number of Task Forces, comprising management and shop stewards, conduct investigations into Working Hours, Productivity Levels, Recruitment and Selection, Courtesy Levels, Training, and Policy Changes. The Task Forces feed back their findings on these issues to the NNC, which can then come to an agreement. The objective is to resolve these issues during the year so that annual bargaining agenda is left as uncluttered as possible. The two-year agreement entered into with SACCAWU in 2006 has facilitated this arrangement because it has provided more time between wage negotiations for the Task Forces to do their work. At other retail firms the bargaining forum has few or no other functions besides annual bargaining over wages and conditions of employment.

Pick n Pay is also noteworthy in that it specifically feeds productivity and training issues into collective bargaining. Most of the other retailers have Employment Equity and Skills Development committees that are separate from the bargaining forum. Training and equity are consulted over in these committees, it seems often without a great deal of involvement by the union. This would appear to be a missed opportunity to link skills acquisition and new grading systems with wage bargaining in a way that would create an incentive for workers to upgrade their skills. The union acknowledge that the separation of collective bargaining from training and employment equity is a problem. It is trying to close this gap by focussing on section 27 of the EEA and broad-banding the grading systems. But the union states that employers are resistant, both with regard to training and changing grading systems. ${ }^{83}$ The union goes on to argue that the SETA is not helping because it is not functioning effectively. However, some retailers state that the union has shown no interest in employment equity and training when they have been approached in this regard.

Skills acquisition should have a positive impact on productivity and performance in the retail sector. ${ }^{84}$ However, this link does not seem to be made in negotiations, and productivity bargaining appears to be virtually non-existent. Clicks stated that it tried to introduce a productivity bonus but "hit a brick wall", while Truworths were unsuccessful when it tried to introduce a performance-related increase based on a performance appraisal. ${ }^{85}$ Pick $n$ Pay recently entered what is termed the Interim Productivity Agreement, but the agreement is focussed exclusively on securing more flexible staffing and working time. At the other extreme, Woolworths have introduced a performance-linked increase based on an assessment, but only after having de-recognised SACCAWU.

83 The predominant grading systems in the sector appear to be Patterson and Peromnes.

84 The standard way of measuring productivity in the retail sector is 'takings per head', but there is recognition that productivity has a number of aspects: skills, flexible staffing, customer service and absenteeism. the unionised staff (29 per cent) are not part of the scheme and rely on negotiated increases. 
Most of the major retailers have signed up to the SACCAWU National Provident Fund and to the Ingwe Medical Aid Scheme (the former is a fund set up by the union while the latter is a scheme promoted by the union). ${ }^{86}$ In most cases it seems that membership of these funds is voluntary, that is, employees have the option of belonging to these funds or to the existing company funds. Benefit funds are a key part of many bargaining councils and, in the case of the Chemical Industry Bargaining, a national provident fund was a precursor and stepping stone to a bargaining council. However, it does not appear that the industry-wide benefit funds are being used by SACCAWU as a way of initiating a centralised bargaining forum.

As indicated above, collective bargaining with the major retailers is well-established, although in some cases it rests on very low representivity. Most of the retailers indicated that they had a very mature relationship with the union. There was acknowledgement of the different interests that firms and the union have but it was made clear that the relationship was a very healthy one. Only one retailer argued that the relationship was not good and blamed the union for this state of affairs ${ }^{87}$ For the rest, retailers spoke of close and regular contact with union officials and a very open relationship. One problem identified by retailers was the length of time taken by negotiations. It was argued by a number of retailers that annual negotiations dragged on unnecessarily and could often have been settled much quicker. Strikes, and particularly misconduct on the part of workers during strikes, were other problems identified by retailers, mainly because they felt that strikes undermined on-going co-operation by the parties in respect of various initiatives that took a long time to revive.

The above section focuses on some of the major retailers. A quite different picture of bargaining emerges when one examines collective agreements reached with many smaller retailers. ${ }^{88}$ These agreements are generally less than a page in length, many are handwritten, and some deal only with a wage increase while others will deal with a wage increase and an annual bonus payment. They are, therefore, collective agreements at their most basic.

However, the agreements negotiated at medium-sized retailers are more substantial, although not as comprehensive as those at most of the national retail groups.

A clear correspondence emerges. The larger the retailer and the wider the scope of the bargaining unit, the more comprehensive is the collective agreement. In other words, size and

86 It was suggested that the union earns a commission from the Ingwe Medical Aid Scheme but this was not confirmed.

87 One of the reasons cited was the union's refusal to agree to a multi-year agreement, when it had done so at other firms. This was given as an example of bad faith on the part of SACCAWU. Interestingly, this retailer was the only one in favour of centralised, multi-employer bargaining.

88 Most of the large retailers at which interviews were conducted provided us with copies of their collective agreements. In addition, SACCAWU supplied us with a large number of collective agreements for retail firms in their Witwatersrand and Northern (Gauteng) regions, as well as collective agreements with medium-sized and national retailers. 
centralisation of bargaining is not only about quantity, it is also about the quality of bargaining. This seems to be logical. Unions simply do not have the capacity to put a lot of time and energy into negotiating an agreement that covers only three or four workers. In such a situation the best a union can do is to engage in a negotiation and try to get an agreement that gives workers one or two improvements. The workers must rely on the sectoral determination for the rest. It is clearly a different matter if the retailer covers thirty or forty thousand workers. In this case a union will invest considerable effort to get as many improvements as it can. The fact that the larger retailers will generally have a much greater ability to pay and to concede to other demands makes the job of the union easier. Centralisation of bargaining therefore means that more workers are covered by collective agreements and unions can better utilise their limited resources, but it also generally means much more comprehensive agreements, with better conditions of employment.

The collective bargaining landscape in the retail sector therefore comprises a number of contours. At the bottom there are a large number of informal retailers that do not comply with the BCEA or the sectoral determination. At the next level there are probably quite a few small retailers that are not organised but do comply with the BCEA and the sectoral determination. The next contour signifies the start of union organisation, but this can be split into a further three layers. The first layer comprises the small retailers that comply with the sectoral determination and are covered by very basic collective agreements that deal with wages and one or two other conditions of employment (according to SACCAWU this layer consists of about 150 firms). The next level is made up of medium-sized retailers (about 250) that are covered by fairly substantial collective agreements. In the top layer are the 30-odd major retailers that have collective agreements of the type outlined above.

\section{What is the Future of Collective Bargaining Arrangements in the Retail Sector?}

SACCAWU believes that a bargaining council is vital for the retail sector. The casualisation of workers and the new franchising trend (with the franchisee explicitly made responsible for industrial relations and collective bargaining) is undermining collective bargaining in the sector. A bargaining council, the union argues, is the best way of dealing with these phenomena and maintaining reasonable labour standards for workers. The obvious problem for the union is its low level of representivity. It was acknowledged by the union interviewee that even if SACCAWU acted jointly with all the unions in the sector they would not come anywhere near reaching the 30 per cent representivity needed to establish a statutory council. What prospects then for a bargaining council?

At this point the prospects appear slim. There was a strong consensus amongst interviewees at retail firms that none of the major retail groups would agree to centralised multi-employer 
bargaining in the sector. ${ }^{89}$ The main reasons were that unions did not have sufficient representivity and that competition was so fierce between retail firms that it would be impossible for them to ever sit down on the same side of a negotiating table and share certain information. Other reasons were the different circumstances facing the different types of retailers (for example, the food retailers and the clothing retailers) and the lack of uniformity in wage levels and conditions of employment between retail firms. The union add a further reason: there is not a strong employers' organisation in the sector. ${ }^{90}$

The union nevertheless has some interesting arguments as to why a bargaining council should be considered for the sector. First, they believe that representivity should not be a simple numbers game. The major retail groups completely dominate the sector and the strategies that these groups adopt determine the fate of small retail operations. Representivity, the union argue, should therefore be determined by the level of union organisation at the big retailers rather than in the sector as a whole.

Second, most workers in the sector currently rely on the protection of the sectoral determination that was introduced a few years ago (that is, Sectoral Determination No. 9). The union believes that the process to arrive at a determination should form the basis for establishing a bargaining council and that government should play a more active role in this regard. SACCAWU's argument is that when the sectoral determination is being reviewed submissions are invited from unions and employers. These submissions can be equated with collective bargaining demands. If the government was to be a bit more interventionist it could take the process a step further and bring the parties together to negotiate those submissions (or demands). In effect, one would then have centralised industry-wide bargaining.

Both the union's arguments are innovative. But they are unlikely to change the minds of any retailers regarding centralised bargaining. Furthermore, the first argument is likely to encounter fierce opposition from small retailers, who would argue that the major groups would use centralised bargaining to squeeze them out. It is also unlikely to convince the Department of Labour which, as we have seen above, is interpreting the requirement of representivity much more strictly. It is unclear how the Department would respond to SACCAWU's second argument. As we have seen above, it has been receptive to the incorporation of centralised bargaining agreements into sectoral determinations in the contract cleaning and private security sectors. However, SACCAWU is proposing a more interventionist role for the

89 Only one employer interviewee was not opposed to centralised bargaining. He believed that conditions at most major retailers were quite similar and there was no reason why they could not negotiate together in a centralised forum.

90 A multi-employer forum does exist in the retail sector, that is, the Retailers Association (RA). It comprises most of the major retail groups but it became virtually dormant and has only recently been revived. It appears to be deliberately low-key. It is not registered as an employers' organisation in terms of the LRA and only industrial relations, employee relations and personnel managers attend the RA's meetings, which appear to be largely about information sharing rather than making decisions. 
Department in the case of the retail sector, one that will probably conflict with the Department's understanding of voluntarism.

A veteran HR manager in the retail sector believes that SACCAWU should give up the goal of centralised bargaining, because their representivity is too low and the major retailers are strongly opposed to it. He argues that the union should rather focus on influencing the sectoral determination process, which he believes it did very effectively when the determination was first introduced, particularly with regard to the position of 'casuals'.

\section{Food Manufacturing}

Food manufacturing encompasses a diversity of operations, including amongst others dairy, milling and baking, red meat, poultry, sugar, the processing of fish, fruit and vegetables, the production of beers, wines and beverages, and sweets and chocolates. There are numerous links between these different operations, and the products they produce: the price at which maize is milled is a determinant of the costs of red meat and poultry, for example, white sugar is a key ingredient of canned fruit, beverages and sweets, amongst other things. For this reason, amongst others, there is a history of economic concentration in food manufacturing, with a handful of conglomerates such as the Premier Group and Tiger Foods with a presence in a number of these operations.

There is also a fairly long history of union organisation in the sector, and of centralised bargaining in a variety of forums since the early 1980s (and in some instances, earlier). In the case of fruit and vegetable canning, bargaining took place in a multi-employer forum. In a number of other sub-sectors national negotiations took place at company level. Where there was no direct internal competition to the company concerned, as in dried fruit processing and brewing, national negotiations were largely a matter of convenience and were relatively unproblematic. But national negotiations implied eliminating regional differentials. In subsectors where there was competition between local manufacturers, agreement to bargain centrally could be seen to put one at a competitive disadvantage. This appears to have been the case in milling and baking, discussed below. Thus at the same time as national negotiations were taking place with companies in the Premier group and SASKO, companies in the Tiger Foods group were fiercely resistant to negotiating at this level.

Industrial councils (now called bargaining councils) have had a chequered history in food manufacturing. For example, there used to be three regional councils in baking, covering the major metropolitan areas of the country. However, by the mid-1980s the employers had collapsed the councils, either because negotiations at national level had rendered them 
irrelevant, or to prevent them being 'taken over' by the emergent unions that were later to form FAWU. ${ }^{91}$ With the sole exception of the sugar industry, where trade union representation was (and still is) fragmented, the only other councils in food manufacturing were small, regional councils, in some instances covering a single plant, and associated with sweetheart unions. ${ }^{92}$ With the exception of sugar manufacturing and a council representing grain co-operatives, all have collapsed.

Today there is still a degree of concentration in food manufacturing, with conglomerates such as Tiger Brands (formerly Tiger Foods) and Pioneer Foods (formerly SASKO), SAB Miller and others operating in different sub-sectors. However, in keeping with a trend amongst employers to focus on what is conceived as their core-business, operations in the different sub-sectors are maintained as separate and distinct from one another. Tiger Brands, for example, recently divested itself of its dairy business (Dairy Belle), on the basis that the operation was not in line with its core business. Collective bargaining for milling and baking takes place separately, as do negotiations for its fruit canning and jam manufacturing operations. Similarly the Premier Group divested itself of certain operations, such as animal feeds, poultry and the manufacture of edible oils. The reconstituted Premier Foods is now focussed only on milling and baking.

There is still centralised bargaining taking place in the food manufacturing sector. However, with the exception of fruit and vegetable canning in the Western Cape and the inshore fishing industry (discussed above with regard to the pelagic fishing forum), there are no multi-employer forums. Moreover, where centralised bargaining is taking place with companies, it appears to be premised on the employer's conception of their core business. Whilst there are companies that bargain in terms of a national recognition or procedural agreement, this appears to be the exception rather than the rule..$^{93}$

The agreements that emanate from such negotiations are generally characterised by their simplicity, particularly when contrasted with the more complex agreements that bargaining councils publish. Sometimes the agreement is no more than a one or two page summary in point form of what was agreed, with statements such as "both parties agreed to maintain the status quo" with respect to a particular condition of work, rather than any attempt to spell out what the status quo is.

Whether because of structural changes in the sector or trade union weakness, it does not appear there is much impetus toward greater centralisation. Collective bargaining in the fruit

91 In Natal (as it then was) this was the Sweet Food and Allied Workers Union. In other parts of the country this was the Food and Canning Workers Union.

92 Baumann's Biscuits Cape Town factory, for example, and Wilson Rowntree's East London factory, were both covered by councils that in effect covered only those plants. Both plants have since closed.

93 Significant national agreements FAWU has negotiated include with SAB Miller and Rainbow Farms. 
and vegetable canning industry is perhaps indicative of the situation on the ground. Whilst a multi-employer negotiating forum has existed in the industry since the 1940s, it was previously constituted through an industry association, the South African Fruit and Vegetable Canners Association. However, whereas in the 1980s the members of the Association represented some fifteen plants throughout the Western Cape, most of them have since shut down. Today FAWU negotiates with three employers, representing four plants, in terms of an informal arrangement to which the Association is not party. It is not even able to persuade these employers to pay the same minimum wages.

The level at which bargaining takes place remains a contested issue. This is illustrated by the case of milling and baking. Each of the three major companies operating in this sub-sector, namely Tiger, Premier and Pioneer, has a history of central negotiations at company level. However, whereas Tiger formerly opposed centralised negotiations, it now prefers to bargain centrally in its bakeries, while still negotiating with its mills at a plant level. Whereas, in the 1980s, Premier was perhaps the first major company to bargain centrally outside the statutory system, it is now a proponent of plant-level bargaining. A national strike over a demand that Premier revert to centralised bargaining coincided with the period of this investigation. The strike lasted some eight weeks, and appears to have ended without the employers conceding on the issue.

The reasons for Premier's opposition to centralised bargaining stem from its past experience. Firstly, it was placed at a competitive disadvantage in having to negotiate centrally while others still negotiated at plant level. Second, the process of negotiation was cumbersome and drawn out, and also highly adversarial. Thirdly, the outcome of such negotiations was often that profitable branches settled for less than they were willing to pay, whereas less profitable branches, or unprofitable branches, were compelled to pay wages they could not afford. Interestingly, Premier was more willing to countenance the possibility of forming a bargaining council for milling and baking. The other two major companies were strongly opposed to this prospect. The reasons advanced for their opposition included losing a competitive advantage as a consequence of the current arrangement, and fear of a loss of control in entering into an industry-wide arrangement.

FAWU has raised the possibility of establishing an all encompassing bargaining forum for food manufacturing as a whole. However, this does not appear to be a realistic prospect in the circumstances. The best prospect for establishing a bargaining council would seem to be in a sub-sector such as beverages and brewing, where there are relatively few major employers with whom FAWU has been negotiating at company level, and where the benefits to both parties are fairly apparent. It appears that negotiations toward establishing a council were fairly well-advanced, with three chambers envisaged, namely alcoholic beverages, non-carbonated soft drinks and carbonated soft drinks. However, agreement to establish a council was not concluded. 


\subsection{Conclusions}

The bargaining council system remains the pillar of collective bargaining in South Africa. It is not about to collapse. On the contrary, it has displayed considerable resilience. However, while the bargaining council system has survived, it is largely confined to those sectors of the economy where there are well-established traditions of trade union organisation and collective bargaining (mainly in the secondary sector), and where the standard employment relationship predominates. This would be true even if the parties in the mining industry were to succeed in establishing a council. This probably makes the expectations that certain trade unions have about extending the system, and achieving greater centralisation, unrealistic.

The bargaining council system faces serious challenges. The falling representivity of parties to councils, and a stricter line on representivity being taken by the Department of Labour, is one of the challenges. Another is the growth of non-standard employment and informalisation. The Cape Building Industry Bargaining Council highlights an anomaly in the legislative framework for bargaining councils with regard to both challenges. Innovative strategies by the council to make inroads into informal (unregistered) firms were successful, but had the perverse consequence that the council parties became unrepresentative and it could not get its agreement extended.

The continued existence of the council provides a good example of bargaining council resilience and is a tribute to its staff. But it should not have been put in this precarious position. The overly rigid interpretation of the representivity requirement by the DoL, in the context of a lack of knowledge about the extent of informal employment within the jurisdiction of councils, provides councils with a disincentive to try to regulate unregistered firms. This will leave the way open for further informalisation and increase the challenge it poses for councils. A solution to this conundrum needs to be found. In this regard, the case of the Bargaining Council for the Leather Industry shows further evidence of innovation on the part of councils. In an industry that is particularly susceptible to cheap imports, the council has demonstrated one way of securing centralised bargaining and maintaining a reasonable level of regulation in the face of informalisation. But this does not remove the need for a strategy to be developed by the Department of Labour to address the regulation of the informal economy, nor for the Department to develop programmes to assist councils.

Statutory councils do not appear to be the solution to the challenges to centralised collective bargaining. Only two have been registered and both have taken a long time to make limited progress. Surely this is not what was envisaged by the negotiators of the new LRA. It was certainly not envisaged that insecure centralised bargaining arrangements would feed into the sectoral determination process rather than establish a statutory council. Although the former shows inventiveness by the bargaining parties, it also highlights the inappropriateness of the route to centralised bargaining offered 
by the statutory council model. What is remarkable in light of the above is that the Department of Labour appears not to have revisited the statutory council model.

Collective bargaining everywhere is a function of trade union strength, and trade union strength is a function of there being significant numbers of workers in standard employment, massed together in the same workplace. Where these conditions prevail, as in the automobile manufacture industry, it is possible to maintain a relatively sophisticated collective agreement without the necessity to establish a bargaining council. However, in food manufacturing, where the industry is quite fragmented, and where many firms have externalised employment, it has not been possible to maintain centralised bargaining arrangements. A vicious circle has ensued, with unions in such sectors struggling to keep up their membership.

The NBF for the Automobile Manufacturing Industry appears to be an example that other sectors should be looking at closely. Whether other sectors can follow exactly what has been done in the automobile industry is debateable; the industry is unique in having only seven employers, all of which are very large. But the NBF appears to have hit on a model, the basic features of which can be transferred to other sectors. It has emphasised the need for the industry to be competitive to survive and grow. This means skilled and productive employees. This, in turn, has meant an agreement that has linked the grading system, the training system and the wage system together, all of which are complemented by a framework for companylevel productivity bargaining. The NBF has, therefore, achieved an articulation of bargaining at industry and company level that has eluded most bargaining councils.

The NBF has also benefited from having broad-banded its grading system and putting a very advanced training system in place prior to the EEA and SDA. The result has been the pursuit of competitiveness via a strategy that benefits workers through skills and rewards. On the other hand, in the retail and food manufacturing sectors the EEA and the SDA have resulted in issues relating to grading and training being hived off from the bargaining agenda and being placed in employment equity and skills development committees. This is probably also the case in many sectors covered by bargaining councils. In these sectors the nexus that the NBF has achieved between the grading system, the training system, the wage system and productivity bargaining therefore becomes almost impossible.

The lack of headway with regard to productivity bargaining is one of the most disturbing features of the current state of collective bargaining. Standing et al noted in 1996:

The lack of attention to productivity issues is particularly striking, which may reflect unions' reluctance to bargaining over them or the belief, on one or both sides of the bargaining table, that these are the responsibility of management. One may anticipate that productivity bargaining will figure more prominently in future collective bargaining (1996: 348). 
It is eleven years on and their prediction does not appear to have become a reality. In fact, it seems to have remained as undeveloped as it was then. Unions are wise to be wary of productivity bargaining, but if the alternative is that it remains the exclusive preserve of management then it is an issue with which unions have to engage. 


\section{An Analysis of the Legislative Framework for Collective Bargaining in the Light of the Empirical Evidence}

The voluntarist approach to collective bargaining adopted in the new LRA meant that it provided a framework for the collective bargaining system rather than a detailed blueprint. A scheme can nevertheless be discerned in the Act. Organisational rights would underpin collective bargaining rather than a judicially imposed duty to bargain. Firm-level bargaining would continue and be supported in the statute but the emphasis of collective bargaining would shift to the industry level, that is, to bargaining councils. Essential to this shift was the retention of the extension of agreements, although the new statute sought to circumscribe the Minister's discretion as well as make it more transparent. Bargaining councils would also need to be more sensitive to small business concerns and the exemption system would become more independent, objective and transparent. Aiding the shift to centralised bargaining would be statutory councils, which would provide a stepping stone (with some compulsion) for unions to set up bargaining councils. Where bargaining did take place at the firm level it would generally be to supplement bargaining council agreements, with much of the focus at firms being on greater consultation and problem-solving in workplace forums. One result would be the reduction of adversarialism.

This scheme has not materialised:

1. Trade union membership has declined sharply, particularly outside the public sector (Du Toit et al, 2006: 42-43). Furthermore, the decentralisation of production and shift to services has made union organisation extremely difficult given the current definition of 'workplace' in the LRA. This has contributed to undermining the usefulness of organisational rights for unions. It is also part and parcel of a shift to services and a huge increase in informal employment experienced over the last decade.

2. Firm and plant-level bargaining is in decline, and seems to have largely disappeared within the jurisdictions of bargaining councils. This strongly suggests that organisational rights have not been an adequate substitute for the duty to bargain. In those sectors where firm and plant-level bargaining continues it seems to be under strong pressure to decentralise and fragment into smaller and smaller bargaining units. Collective agreements for such units and firms are often very limited, dealing with wages and a few other basic conditions of employment. In these sectors there is little realistic likelihood of statutory councils or bargaining councils being established.

3. The jury is still out on the state of the bargaining council system. The number of councils is sharply down but the number of employees covered has increased. There are other positive developments in the system but also some serious threats to it. However, the 
changes introduced by the LRA do not appear to have assisted the system very much. The Act certainly does not appear to have promoted bargaining at the central level or fused the fragmented system of bargaining councils into a more coherent whole.

4. Representivity is probably the biggest problem facing bargaining councils. Flowing from this are problems with the extension of agreements. This has a number of aspects. The first is simply arithmetical: how does one establish the representivity of parties when one does not know and can hardly even guess at the number of employers and employees in the relevant sector. The Department of Labour's solution is to use the number of registered employers and employees. Besides the fact that this method ignores the informal part of sectors, it also introduces a disincentive for councils to go out and find informal firms to register (Godfrey et al, 2006: 47-84). The Cape Building Industry Bargaining Council provides an example of the perverse consequences of the current situation.

5. The second and more substantial aspect of the representivity problem is that many parties are struggling to maintain representivity. There are many explanations for this, not least of which is probably that many parties are not particularly effective at organising and servicing members (as one sees in the case of the Cape Building Industry Bargaining Council). But the definition of 'workplace' and the unsuitability of the organisational rights regime are also part of the explanation. However, the Minister has a discretion where parties fall below the representivity thresholds. This should be exercised in favour of extension if non-extension would undermine collective bargaining at the sectoral level. Currently the latter condition seems to be ignored and the Minister (via Department of Labour officials) is taking a tougher line on extensions. The reason for this tougher line is ostensibly to put pressure on the parties to councils to get their act together and up their representivity. But this policy shift - and it is a policy shift - is taking place in the absence of any programme to assist councils or the parties to councils. Furthermore, there is considerable opaqueness in the exercise of the Minister's discretion so it is difficult to establish whether there are other reasons for the policy shift.

6. A third aspect of the representivity problem relates to small enterprises. This was discussed in some detail by Godfrey et al (2006: 25-30 and 97) and only needs a short mention here. Currently there are two 'hard' thresholds in the LRA for representivity. One measures employees at party firms as against all employees, and the other measures party trade union members as a proportion of all employees. However, the first of these measures facilitates dominance of bargaining councils by large firms. A third measure - party firms as a proportion of all firms - would counter this bias, but is not included 
in the Act. Furthermore, with three measures there could be more flexibility in the interpretation of 'sufficiently representative', that is, councils that were representative on only one measure could qualify as sufficiently representative because they had reasonable representation in the other two measures.

7. The safety valve for non-party firms, particularly small non-party firms, in the face of extensions is the exemption system. Prior research by Godfrey et al (2006) showed that this system was working relatively well. This makes the tougher line being taken by the DoL somewhat surprising. It also makes the continued clamour over extensions by the small business lobby surprising, particularly when our research shows that small firms seem to not apply for exemptions mainly out of ignorance (although we recommend more research on this issue).

8 It is not easy to get past the rhetoric of small business concerns about labour regulations. We do not believe that large-scale surveys are a very effective way of doing it. Our qualitative interview method gives one more depth but is still concerned with perceptions rather than 'hard' measures of the costs imposed by labour regulations. This problem aside, the small business lobby remains implacably opposed to the extension of bargaining council agreements. Our interviews, however, reveal that a major concern of many small businesses registered with councils is not the extension of the agreement but the fact that the council is not enforcing the agreement effectively. In other words, councils are not making regulatory inroads into the informal parts of their sectors. Furthermore, the opposition to bargaining councils and other labour market regulations is often coloured by a great deal of ignorance.

9. One must nevertheless take account of the arguments made by the small business lobby. They have a certain political weight and their arguments carry some force in the context of an extremely high level of unemployment. Some bargaining councils have become more sensitive to small business concerns, but there is little sign of greater involvement of small enterprises in the mandating process within employers' organisations, or of more employers' organisations that just represent small businesses participating on bargaining councils. In this regard the requirement in the LRA that councils must provide for representation of small and medium enterprises has not been effective. The result is that the small business lobby continues to criticise the extension of bargaining council agreements. 
10. Writing off statutory councils will always be open to the criticism that one should just give them a bit more time. But why should one give them more time if there is the possibility of modifying the system or developing a more viable alternative? The problem is that there does not appear to be much enthusiasm for re-visiting the statutory council model.

11. Articulation between firm or plant-level bargaining and bargaining councils is not working. The prevailing trend is for bargaining councils, at the instigation of employers, to prohibit dual-level bargaining. In other words, the solution to the problem of conflict between bargaining at different levels is simply to rule out one level of bargaining, and in the process any need for articulation. So, rather than bargaining councils fashioning innovative agreements that provide scope for firm or plant-level over certain issues or within certain parameters, they are becoming proponents of one-level bargaining. Productivity bargaining appears to have been a victim of this shift. ${ }^{94}$

12. One could apply the same defence of statutory councils to workplace forums, that is, they just need a bit more time. We, however, disagree. The fact of the matter is that workplace forums as currently envisaged in the Act are a dead duck. What is remarkable is that they have been left untouched in the LRA despite a number of rounds of amendments to the statute. In the light of the decline in firm and plant-level bargaining a decision needs to be made about the appropriate vehicle through which engagement can take place at this level, particularly with a view to supplementing centralised bargaining.

13. Such an endeavour will have to deal with the EEA and SDA. The requirements of these statutes have led to many firms setting up employment equity and skills development committees. The effect has been to divorce grading and training issues from the bargaining agenda. These issues are however critical if one wants to link skills to rewards. So the vehicle that is developed for the firm or plant-level will have to deal in some way with this issue.

14. An interviewee at an employers' organisation in the security sector stated that the final count they had arrived at was 88 deaths arising from the 2006 strike. This, he added, was more than the total number of deaths in the 1922 Rand Revolt or at Sharpville. If the figure is correct it makes it the bloodiest strike in the country's labour history. The

$94 \quad$ This is not to say that productivity has not been increasing. The fact that over the last decade employment growth has consistently been lower than output growth attests to rising productivity, albeit at a declining rate (Bhorat and Oosthuizen, 2004: 6). The point is that this productivity improvement has in the main not been the result of agreements between unions and employers. 
strike also came after three years of rising industrial action and surely contributed to a continued upward trend in 2006, one that almost certainly climbed steeply in 2007.(Du Toit et al, 2006: 51) It is impossible to say whether this trend is evidence of more or less adversarialism compared to 10 or 15 years ago, but it indicates that the new LRA has not significantly reduced adversarialism, or intimidation and violence.

In the light of the above, the question one must ask is whether to persevere with the framework provided by the LRA for collective bargaining because it is in principle sound? ${ }^{95}$ Or does one need to re-think the framework given the changes that have occurred in the labour market over the last decade? We are unequivocally of the latter school

A serious re-think does not necessarily translate into a radical overhaul of the framework for collective bargaining. Continuity is essential in industrial relations systems. One also needs to take account of where the system and parties are currently. This was the purpose of the empirical component of this research project. Whatever one attempts must be sensitive to this reality. Furthermore, there are some positive developments in the collective bargaining system. It would be wise to use these as possible models towards which the system should be steered. However, it is important that any proposals must recognise political constraints. It would therefore be unrealistic to try to provide support for collective bargaining by recommending compulsory centralised bargaining or the automatic extension of agreements irrespective of the representivity of parties.

Below we put forward some recommendations or policy options. These are serious proposals but have not been worked out in every detail. We do not believe it is our task to re-write the provisions for collective bargaining in the LRA. In any case, any proposals we make will need to be thoroughly debated by government, business and labour. The recommendations are therefore aimed at stimulating this debate rather than coming up with a comprehensive package of solutions.

What are the strengths of the current system? Besides the gloomy picture presented by the empirical research and the above analysis, there are some strengths. First, one has a relatively resilient bargaining council system that has been adapting to changed conditions. Second, one has the example of the NBF, which has fashioned sophisticated centralised collective agreements that articulate with plant-level bargaining, within an adversarial industrial relations environment. Third, one has a tradition of strong shopfloor organisation (although this is in decline). One needs to build on and support these strengths in meeting the broad purpose of the LRA through the collective bargaining system, viz. "to advance economic development, social justice, labour peace and the democratisation of the workplace". The objective is

95 This is apparently the position of the Minister of Labour, who has stated that the legislative framework is sound and that it is just a question of more effective enforcement of the statutes. 
therefore to create a strong collective bargaining system that can ensure redistribution and industrial democracy as well as contribute to economic development.

\subsection{Policy Recommendations}

The level at which bargaining takes place remains a central concern of the collective bargaining system. The task team that designed the first version of the new LRA debated three models for collective bargaining that were largely focused on the level of bargaining issue: first, a statutory duty to bargain underpinned by statutory determination of the level of bargaining and bargaining topics; second, that courts determine appropriate levels of bargaining and bargaining topics; and third, a voluntarist system in which the parties determine their own arrangements through the exercise of power. The team chose the voluntary model. Perhaps it is time to re-visit other options.

The first prize for many unions would be a centralised bargaining system imposed by statute. This, however, appears not to be a realistic option at the current conjuncture. It can also be argued that such a system would in the long-term weaken rather than strengthen unions, because with the guarantee of centralised bargaining they would increasingly ignore shopfloor organisation.

We believe that, as an alternative, two options should be explored by labour, business and government. The first of these options proposes a limited programme that does not require any amendments to the LRA but rather relies on the efforts and creativity of the parties. This option sees the Department of Labour playing a much more proactive role in supporting bargaining councils. It can do so by re-visiting its current approach to the interpretation of 'sufficient representivity' for the purpose of extending bargaining council agreements. It can also develop programmes to support and assist bargaining councils, disseminating best practices and coordinating systems and resources. Furthermore, the National Productivity Institute, which we understand is housed within the Department, should be tasked with assisting councils and the parties to councils with productivity bargaining.

The parties to bargaining councils can also play their part to increase their representivity by the simple expedient of incentivising participation. Council must offer benefits that are only available to parties. For example, if councils do prohibit firm or plant-level bargaining over issues in their main agreements then this provision should not be extended. Party trade unions can then approach those firms with a view to bargaining improvements to the council agreement. To avoid the threat of bargaining, the employer can simply join a party employers' organisation. Similarly, benefit fund agreements should not be extended. Why should pension/provident, medical and other benefits be made available to non-parties? If the firm and employees want to access these funds then they should join the party employers' 
organisations and unions. At the same time, if a non-party employer finds these onerous then it does not need to join. ${ }^{96}$

An area in which bargaining councils can be given more assistance is dispute resolution. Bargaining councils are firmly in favour of performing this function within their jurisdictions. But the subsidy must be increased or dispute resolution becomes a drain on councils' finances. Given the inadequate subsidy it seems unreasonable that councils should be required to perform dispute resolution for non-parties where their agreement has not been extended (as is currently the case for the two bargaining councils in the building industry included in this study).

The Department's more proactive role should not be limited to support for the bargaining council system. It needs to also give attention to those sectors without a tradition of union organisation and collective bargaining, where non-standard employment and informalisation are prevalent. Innovative thinking will be necessary for these sectors. One might try to develop entirely new forms of collective bargaining. This is not as far-fetched as it may sound. For example, there is growing recognition that collective bargaining is a possibility for people who are ostensibly self-employed (for example, street vendors or traders) or do not have an easily identifiable employer (for example, home-based workers that are engaged through an intermediary to produce for someone else). Organisations such as the Self-Employed Women's Association of India (SEWA), and its South African counterpart, the Self-Employed Women's Union (SEWU), ${ }^{97}$ have shown that alternative forms of unionisation can pursue collective bargaining in the informal economy.

In fact, Streetnet International, ${ }^{98}$ a global network of trade unions, associations and cooperatives organising in the informal economy, has developed a model for collective bargaining in the informal economy. In terms of this model, there are a range of issues affecting these workers over which bargaining can take place, and a range of possible negotiating partners, such as municipal authorities and even the police, regarding the manner in which regulations are enforced, the confiscation of goods and the like. ${ }^{99}$ Although this extended notion of collective bargaining is of limited practical application in the absence of organisations of workers in the informal economy, it is a development of which union strategists and government policy-makers should be aware.

$96 \quad$ Bargaining council benefit funds are an area of concern. However, we are aware of research that has been done by the National Treasury on these funds. We believe that this is part of a much bigger process to introduce a national retirement scheme. It is, therefore, possible that bargaining council benefit funds are going to be incorporated in some way into such a scheme. This will need to be done with sensitivity to the important role of benefit funds in the bargaining council system.

97 Unfortunately, SEWU no longer exists.

98 Streetnet International is currently based in South Africa.

99 See www.streetnet.org.za, Report, Streetnet International Meeting on collective bargaining in the informal economy, 26-30 March 2007. 
The second option that can be explored proposes a more extensive change to the current legislative framework. This option starts with the reintroduction of the duty to bargain enforceable by the Labour Court. This would mean dropping organisational rights from the statute and probably mean revisiting the definition of 'workplace'. The problem of the level at which to impose the duty can be dealt with by providing that the Labour Court can make an 'order' recommending to the parties the level at which bargaining should take place. Should an employer refuse to follow such an order the union or unions can resort to power.

There should, however, be exceptions to this general rule. For example, an idea that was much in vogue at the time that the new LRA was being negotiated, was the framework agreement. Such an agreement would be bargained at a bargaining council or other centralised forum but would include only a minimum set of employment conditions and minimum wage rates. Further bargaining would then take place at firm and plant level to add employment conditions as well as improve on the minimum conditions and wages in the framework agreement, that is, to negotiate 'actual' wages.

This model appears to have been virtually forgotten. In fact, in recent years the trend has been in the other direction: employers have consistently refused to negotiate at two levels and it appears that a number of trade unions have gone along with them in return for the ability to negotiate 'actual' wage increases at councils. It seems to be the worst of both worlds. Trade unions are shifting their focus away from the workplace to the central level and 'actual' increases are being extended to small firms that struggle to keep up with the conditions set by councils. Productivity bargaining, which can link increases to performance at the level of the firm, has been a casualty of this process.

In order to promote framework agreements and productivity bargaining, the LRA could impose a duty to bargain at a bargaining council where the council can show that it has a framework agreement in place that provides only for minimum conditions and where bargaining at firm or plant-level is envisaged. While bargaining at the firm or plant-level would be left to the power play of the parties, such a duty would mean that an employer would not be able to leave the bargaining council if it was in addition forced by a sufficiently representative union into bargaining again at firm or plant-level. This should give support to centralised bargaining while at the same time boosting firm and plant-level bargaining. It would also be a way through the impasse over dual-level bargaining. And it would mean less onerous agreements for small unorganised firms, that is, they would be bound only by the framework agreement.

A second exception would be where the employer falls within the jurisdiction of a statutory council. In such a case the Labour Court should be able to order an employer to bargain in the council. In other words, we propose that statutory councils are retained but with the added support of a judicially imposed duty to bargain. 
At the workplace level it is essential that a vehicle is created that can develop productivity agreements, build workplace democracy and reduce adversarialism. To do so the workplace forum model needs to be radically revised. Workplace forums should be made compulsory for all firms with fifty or more employees. However, the statute should limit their compulsory powers to information sharing, with the proviso that sufficiently representative trade unions can upgrade the powers of the forum to consultation and thereafter joint decision-making once they believe that the worker representatives have the necessary skills to engage at these levels. For firms in the twenty to thirty worker range, a majority of the workers located at the workplace should be given the power to trigger a workplace forum. Such a workplace forum would also initially only have the power of information sharing but can upgrade its powers to consultation and joint decision-making over time. Importantly, the latter threshold of twenty to thirty workers should include the employees of the firm and all other workers at the firm, that is, workers supplied by contractors or labour brokers.

Furthermore, funds should be accessed from the National Skills Fund and from SETAs for a training programme for representatives on workplace forums. This will allow such representatives to develop skills while getting access to information at firms. ${ }^{100}$ Experts from the National Productivity Institute can also assist representatives (as well as management) with regard to productivity issues.

In addition to the above, the LRA, EEA and SDA need to be re-examined to ensure that there are no obstacles in the way of grading systems, training and productivity incentive schemes forming a nexus that will incentivise skills development and improved performance. It will, therefore, probably be necessary to legislate that skills development and employment equity are compulsory consultative issues for workplace forums. Grading and productivity incentive schemes can be added later at the behest of the union.

While unions might be wary of workplace forums we believe that they are missing an opportunity to use these forums to address the problem of non-standard employees. Such workers generally pose challenges for union organisation, particularly where the workers have been externalised. However, if the LRA were to expand the scope of a workplace forum to represent all workers (not just employees) in the workplace then forums could become a bridge between standard and non-standard employees.

100 See Godfrey and Du Toit (2000) for a full explanation of this proposal. 


\section{References}

Anstey, M. 2006. 'Forming, storming, norming and performing: transformation of labour relations in the South African automobile industry', South African Journal of Labour Relations, Vol.30 No. 1.

Bezuidenhout, A., Godfrey, S, Theron, J. \& Modisha, M. 2004. Non-standard employment and its policy implications. Research report submitted to the Department of Labour.

Bhorat, H. \& Oosthuizen, M. 2004. What have we learnt about the South African labour market? Unpublished paper prepared for the National Treasury.

Butcher, K.F. \& Rouse, C.E. 2001. 'Wage Effects of Unions and Industrial Councils in South Africa'. Industrial and Labor Relations Review, Vol. 54, No. 2

Chamber of Mines website: www. bullion.co.za

Chamber of Mines. 2005. Labour Policy Digest (March).

Chamber of Mines. 2006. Labour Policy Digest (July).

Chamber of Mines. 2006. Labour Policy Digest (November).

Chamber of Mines. 2007. Labour Policy Digest (March).

Draft Negotiating Document in the Form of a Labour Relations Bill, Notice 95 of 1995, Government Gazette No. 16259 dated 10 February 1995.

Du Toit, D., Bosch, D., Woolfrey, D., Godfrey, S., Cooper, C., Giles, G. S., Bosch, C. \& Rossouw, J. 2006. Labour Relations Law ( $5^{\text {th }}$ edition). LexisNexis Butterworths: Durban.

Godfrey, S. \& Du Toit, D. 2000. 'New proposals on workplace forums: Opportunity or threat?' South African Labour Bulletin, Vol. 24, No.6 (December).

Godfrey, S., Maree, J. \& Theron, J. 2006. Conditions of Employment and Small Business: Coverage, Compliance and Exemptions. DPRU Working Paper No. 06/106, Development Policy Research Unit, University of Cape Town.

Holtzhausen, M. \& Mischke, C. 2004. 'Bargaining Councils in other sectors of the South African Economy', in an unpublished report entitled Joint Investigation by the Chamber of Mines and the National Union of Mineworkers into the Various Bargaining Options compiled by the Chamber of Mines and the National Union of Mineworkers.

Horwitz, F. 2000. Report of the Commission investigating the effects of sub-contracting on collective bargaining in the Building Industry in the Western Cape. Unpublished report. 
Icharam, M. 2004. 'Bargaining Councils in other sectors of the South African Economy', in an unpublished report entitled Joint Investigation by the Chamber of Mines and the National Union of Mineworkers into the Various Bargaining Options compiled by the Chamber of Mines and the National Union of Mineworkers.

National Contract Cleaning Association website: www.ncca.co.za

Nicol, M. 1985. Minimum Wage Statistics: Taking the pulse of the Industrial Council System. South African Labour and Development Research Unit, University of Cape Town.

Rankin, N. 2006. The Regulatory Environment and SMMEs. Evidence from South African Firm Level Data. DPRU Working Paper 06/113. Development Policy Research Unit, University of Cape Town.

Spowart, M. 2004. Industrial Relations Structures and Arrangements in the South African Mining Industry. Chamber of Mines.

Standing, G., Sender, J. \& Weeks, J. 1996. Restructuring the labour market: The South African challenge. International Labour Office: Geneva.

Streetnet International website: www.streetnet.org.za

Webster, E. 1999. ILO Research Project on the Contribution of Collective Bargaining to Employment Protection or Creation and to Competitiveness: The Case of South Africa. Sociology of Work Unit (SWOP), University of the Witwatersrand. 


\section{Appendix 1: Methodology}

Various research methods were used in order to investigate the research questions in the three sub-projects and in the more analytical and conceptual phase of the project.

The first sub-project focussed on the bargaining council system. In doing so, it built on earlier research (see Godfrey et al, 2006) that had raised the question whether the bargaining council system was in a crisis. This question had been posed because the research showed that the number of councils had reduced significantly in recent years and there were indications that the downward trend was set to continue. Furthermore, the continued attacks on the bargaining council system from small business, the inability of councils and small business to find a solution to their problems, and the proportion of unregistered firms operating within the jurisdictions of some councils, pointed to the system being in crisis. However, the prior investigation concluded that more research was required before one could answer the question.

The first sub-project, therefore, examined the state of the bargaining council system, to establish what threats it faces and how these can be overcome. The sub-project examined six bargaining councils, one of which is under extreme pressure and has effectively ceased to function as a collective bargaining forum. The bargaining councils were selected according to a number of criteria, including the size of the council, levels of representivity, sizes of firms covered by the council, estimates of non-registration within its jurisdiction, and estimates of non-standard employment within its jurisdiction.

Various key players on the councils were interviewed (that is, council secretaries, representatives of employers' organisations, and representatives of trade unions) with regard to the challenges facing the council and the system more broadly. The interviews explored the issue of non-registration of small firms and the threats posed by non-standard employment but were not limited to these issues.

The latter issue was also explored through interviews with parties on the three existing statutory councils (two of which are registered and one of which has been established but is yet to be registered) as well as through interviews with some of the parties of proposed statutory councils that never lasted the course.

In addition, a key official at the Department of Labour (DoL) was interviewed regarding the Department's policy on bargaining councils and any programmes that it might have to support councils. A particular focus was the current policy of DoL on the extension of council 
agreements. DoL officials were also asked questions regarding the establishment of statutory councils and apparent problems with this process.

An important objective of all of the above interviews was to get perspectives on how problems could be addressed and what needed to be done to promote an effective bargaining council system.

The second sub-project examined the state of collective bargaining outside the bargaining council system. Given the time constraints it was not possible to do a comprehensive examination of bargaining outside the bargaining council system. We, therefore, examined three categories of bargaining in selected sectors.

Firstly, we identified three sectors in which non-statutory centralised bargaining forums existed. These forums were examined, with the focus being on the advantages and disadvantages of the non-statutory forum as opposed to a bargaining council from the perspective of the parties. Interviews were done with the employers, employers' organisations and trade unions involved in these forums to establish their strengths and weaknesses as well as future plans.

Secondly, we examined what can be termed quasi-statutory centralised bargaining forums. These types of arrangements have emerged in the security and cleaning sectors, primarily driven by employers that are seeking to set a floor for competition. The 'collective agreement' is then fed into the sectoral determination with the approval of the relevant trade unions.

Thirdly, we examined decentralised bargaining arrangements, that is, bargaining at the enterprise or plant level. The examination of the state of decentralised bargaining was necessarily limited in scope. This component of the research sought to establish the extent of bargaining and the nature of the agreements in sectors covered by a sectoral determination (that is, the retail sector) and a sector not covered by a sectoral determination (that is, the food manufacturing sector). Interviews were conducted with the major unions in the two sectors as well as with a sample of employers in the sector. Some of these interviews were conducted face-to-face but most were conducted telephonically. These interviews explored issues such as the nature of collective agreements, the scope of coverage of agreements, and the forms of flexibility built into agreements.

The third sub-project sought to fill a gap in previous research on the bargaining council system by doing interviews with a sample of owners of small businesses. The aim was to get their perspectives on the alleged constraints that various forms of labour regulation imposed on them. For the purpose of the research a small business was loosely defined has employing fewer than twenty workers. The sample was stratified in the following way: five interviews were done with businesses that had been referred to in articles in the Big News newspaper (these articles are generally highly critical of bargaining councils and highlight alleged destruction 
of small businesses by council regulations); five interviews were done with businesses that were parties to a bargaining council; five interviews were done with businesses that were non-parties in sectors covered by bargaining councils; five interviews were done with small businesses in sectors covered by a sectoral determination; and, five interviews were done with small business owners in sectors covered only by the Basic Conditions of Employment Act. A total of 25 small business persons were interviewed. Most of the interviews with small business owners were conducted face-to-face but some were conducted telephonically.

The fourth component of the project was primarily conceptual. The questions we asked in this phase sought to integrate and build on the empirical evidence generated by the three empirical sub-projects. This component, therefore, involved analysis of the empirical data, legal analysis of legislation, and also drew on secondary sources. The thrust of this component of the project was prospective. In other words, it sought to establish how collective bargaining could be strengthened and improved in future through policy interventions, amendments to statutes, and explorations of alternative models and practices by the parties. This prospective orientation, however, was based on the empirical analysis of the current state of the collective bargaining system.

Note that the original research report provides a full list of all interviewees. This list can be obtained from the authors. However, many of the interviewees at small businesses spoke on condition of anonymity. The authors will, therefore, not provide any of the names of the latter interviewees or the names of their businesses. 


\section{Appendix 2: A Critique of Large-Scale Surveys}

Qualitative interviews and large-scale surveys are primarily focussed on perceptions. Both methods, therefore, suffer from certain limitations. Surveys seek to overcome these limitations by examining a large number of respondents to produce 'measures' by ranking responses, and in some cases linking perceptions with firm characteristics in such a way that explanations can be adduced for the perceptions. ${ }^{101}$ A qualitative approach uses a limited number of in-depth interviews to produce relatively 'thick' qualitative data in which explanations can be found and causal connections can be explored. The two methods can, therefore, complement one another. But the strengths of one also suggest criticisms of the other. In this section we will examine critically a study done by Rankin in which he analyses data from a number of largescale surveys that inter alia sought to measure the impact of labour legislation and regulations on small firms. ${ }^{102}$

The first point is that the survey method makes it difficult to understand exactly which legislation or regulations are the object of respondents' perceptions. The broad category of "labour regulations" or "labour laws" does not help in this regard. There are a number of points in Rankin's study that highlight this problem. For example, Rankin uses the NES survey to examine the relationship between "labour regulations" and hiring new employees; between "labour regulations" and the costs of production; and, "recent labour laws and regulations" and certain potential benefits (2006: 42-44). To what "labour regulations" or "recent labour laws and regulations" are respondents referring? Probably to the new LRA, the BCEA and the EEA; possibly even the SDA. However, it is not made clear in the study.

The problem is that the NES survey was published in 1999, and with regard to questions in the survey it used 1998 as a cut-off (as did the WB/GJMA survey) (Rankin, 2006: 8). However, the BCEA came into effect only from December 1998 ${ }^{103}$; the EEA commenced only in December 1999104; and the SDA commenced only in September 1999. ${ }^{105}$ The respondents must, therefore, be referring to the new LRA, the old BCEA and the Wage Act (and possibly statutes such as OHSA, COIDA and the 1966 UIA). Given that the old BCEA and the Wage Act have been repealed and replaced by the new BCEA, and additional new statutes have

101 For example, size of firm, age of firm, capital/labour ratio, skill composition, and sector.

102 The main objective of these studies was to identify constraints, regulatory or otherwise, on firms. Labour legislation or labour regulations are therefore generally ranked against other regulations and constraints.

103 Although it was passed by Parliament in 1997

104 Although it was passed by Parliament in 1998

105 It was passed by Parliament in 1998 but commenced only in September 1999 
been introduced, what is the use of this data? At best it is not very useful and at worst it is misleading. ${ }^{106}$

A further example of this problem is found with Rankin's analysis of the WB/GJMA survey. With regard to the question: "Do Labour Regulations Affect Firm Growth?", data on employment patterns from the WB/JGMA survey is examined for the period 1994-1998, which we are told covers the implementation of the LRA, the BCEA and the EEA (Rankin, 2006: 36). Included is the SDA, because a question on this statute was included in the survey instrument. However, as we note above, the EEA and SDA came into effect only late in 1999, while the BCEA was implemented only at the very end of 1998 . How can employment patterns, that is, increases or decreases in employment, for the period 1994-1998 be linked to the impact of these statutes? The subsequent more detailed analysis of the impact of the BCEA on firm growth, and the findings that it led to slower firm growth across the period, are therefore meaningless (Rankin, 2006: 37-39).

A second problem relates to the one above. Even if one has agreement on the set of labour legislation or regulations that is being examined, then which particular ones are respondents talking about when they answer questions. Most of the surveys that Rankin analyses in his study appear to have used post-coding of interviewees' responses. This means that a large variety of responses that mention aspects of labour regulations that respondents find problematic or perceive as obstacles are subsequently classified into an encompassing category such as "labour regulations". Even if the surveys were not post-coded the same problem arises. Respondents must have been given, as one of a number of categories, a category such as "labour regulations". This forces the respondent to choose the entire category when only a particular aspect of labour regulations is perceived as problematic. Either way, one loses a lot of important detail about specific aspects that are problematic and how respondents weight those aspects. It is a significant limitation if one is seeking to base policy decisions on research. "Labour regulations" might in fact be largely made up of negative perceptions relating to the dismissal regime. Some adjustment to the latter will then solve much of the problem, whereas the survey method suggests that the entire gamut of labour regulations is at fault.

Rankin attempts to deal with the above problem by identifying a number of areas of the labour regulations (for example, "firing or dismissal procedures", "working time", and "affirmative action provisions"), and examining the impact of these on issues such as "hiring new employees" and

106 Adding to the confusion is a reference in the concluding section of the report to the 1998 and 2002 surveys.(2006: 69) This presumably means the WB/GJMA surveys done in 1998 and 2002. It is unclear why the 2002 survey is mentioned at this point when it does not appear to have formed part of the Rankin's study. The reference also concludes that there was little or no change in perceptions regarding labour regulations in the two surveys. Can one therefore conclude that the new BCEA and the EEA and SDA have had no discernible impact on employers' and managers' perceptions? 
"costs of production". The problem is that he uses the NES survey for this exercise. As noted above, this survey used 1998 as a cut-off date, that is, prior to the implementation of the EEA and the SDA, and only captured one month of the new BCEA. This makes categories such as "hiring procedures" and "affirmative action provisions" problematic, given that the EEA was not in effect and these issues were, therefore, not regulated by labour legislation. And categories such as "working time" and "leave provisions" are not very useful because they very likely refer to the 1983 BCEA.

A third problem flows from the emphasis the surveys place on the negative aspects of labour regulations to the virtual exclusion of the benefits. For example, Rankin's analysis of the World Bank's ICA (Infrastructure Consortium for Africa) finds that 'skills and education of available workers', 'macroeconomic stability', 'labour regulations', and 'crime, theft and disorder' are by a considerable margin the most frequently mentioned obstacles to business. Rankin states that, of the four, only 'labour regulation' is directly related to government regulation. This is surely too narrow a definition of government regulation. It focuses only on regulation that is directly a constraint on the market rather than regulation that is enabling or promotional. The most frequently mentioned obstacle was 'skills and education of available workers'. Is this not directly related to government regulation? Surely, the education and skills development systems are largely the responsibility of government. The only difference is that in this case employers are identifying a failure of government regulation to supply sufficiently educated and skilled workers, rather than the success of government to provide workers with employment rights. A similar sort of argument can be made with regard to statement 'crime, theft and disorder'.

The qualitative interviews done for this study throw up another challenge to the large-scale surveys. If interviewees' knowledge of labour legislation and regulations is generally quite poor, then how much weight does one place on comments that "labour regulations" or "labour laws" are major obstacles for small firms? As noted at the start of this section, both in-depth interviews and large-scale surveys rely on perceptions. Perceptions do not necessarily reflect reality or translate into action. However, perceptions are important if they state the way management is thinking and would form the basis for decisions on the part of employers and managers. But, if management's perceptions are based on limited or incorrect information, and are contradictory, then the validity of one's data is undermined. With in-depth interviews one is able to test perceptions and identify where respondents are over-reaching their knowledge in the claims that they make. One can also identify inconsistencies and contradictions. The largescale surveys take the respondents' answers at face value. This is dangerous: ideology rather than the systematic application of knowledge appears to play a very large role in determining perceptions regarding regulatory constraints. The consequence might be to change labour regulations in response to employers' perceptions, whereas the most appropriate action would be to improve the knowledge of employers. 